\title{
The Influence of Calcium on the Growth, Yield, Quality, and Chemical Composition of Watermelons, Citrullus vulgaris Schrad.
}

\author{
By \\ WILLIE ESTEL WATERS
}

\begin{abstract}
A DISSERTATION PRESENTED TO THE GRADUATE COUNCIL OF THE UNIVERSITY OF FLORIDA

IN PARTIAL FULFILLMENT OF THE REQUIREMENTS FOR THE DEGREE OF DOCTOR OF PHILOSOPHY
\end{abstract}

UNIVERSITY OF FLORIDA

January, 1960 


\section{ACKNOWLEDGEMENTS}

The author wishes to express his sincere appreciation to Dr. V.F. Nettles, Professor of Vegetable Crops, for guldance and suggestions throughout this study.

The helpful advice and assistance of the other members of the supervisory combittee, Dr. W. O. Ash, Dr. F. S. Jamison, Dr. D.F. Rothwell, and Dr. B. D. Thompson, is gratefully acknowledged.

Appreciation is expressed to all nembers of the Vegetable Crops Department for the1r interests and cooperation during this study.

The author is also indebted to his wife, Mary Elizabeth Waters, for assistanco in the preparation of the manuscript and for continued derotion and encouragement. 
CONTENTS

Page

LIST OF TABLES . . . . . . . . . . . . . . v

LIST OF ILLUSTRATIONS ............... . vili

INTRODUCTION . . . . . . . . . . . . . . . I

REV IEW OF ITTERATURE . . . . . . . . . . . . 3

Mineral Nutrition of Cucurbits .......... 3

Effects on Yleld ............... 3

Effects on Quality ............ : 5

Efrects on Sex Expression and Fruit Set. - : 7

Effects on Blossom-end Rot ......... 8

Calcium in Plant Nutrition ........... 10

Role in the Soll ............... 10

Role in Plants.................. 11

Cations in Plant Tissue ............. 13

Cation Accumulation ........... 13

Effects of Nitrogen on the Cation Content : i7

Distribution of Cations in Plants....... 18

METHODS AND PROCEDURES ............... 20

Greenhouse Phase ................ 22

Fleld Phase ................. 25

Description of Soll Type and Soll Test . . . 25

Field Methods . . . . . . . . . . . . 26

Tissue Samples ............... 28

Chemical Analyses ............... 29

Statistical Methods ............... 30

RESULTS OF EXPERIMENTS ............... 3I

Greenhouse Phase . . . . . . . . . . 35 
Page

Growth Responses ............. . . . 35

Sex Expresgion and Fruit Set... . . . . . 42

Chemical Composition ... . . . . . . . 45

Fleld Phase . . . . . . . . . . . . 48

So11 Test8................ 48

Growth Responses......... ..... . . 50

Fruit Set ... . . . . . . . . . . . . 56

Chemical Composition... . . . . . . . . 57

DISCUSSION . . . . . . . . . . . . . . . . . . 69

Growth Responses . . . . . . . . . . . . . 69

Sex Expression and Frult Set . . . . . . . . 77

Chemical Analyses . . . . . . . . . . . . 78

SUMMARY AND CONCLUSION . . . . . . . . . . . . . 84

REPERENCES CITET . . . . . . . . . . . . . . . . 90

APPENDICES . . . . . . . . . . . . . . . . . . 97

A - Detailed Soll Test Results by Plot . . . . . 97

B - Analyses of Vartance Tables . . . . . . . 100

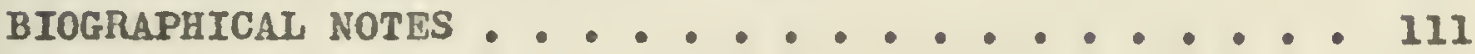




\section{LIST OF TABLES}

Table

Page

1. Calcium levels in greenhouse solution cultures . 23

2. The composition of the basic nutrient solution for greenhouse expertment. . . . . . . 24

3. Total bi-monthly rainfall recorded at the hol'ticulture Unit March 1 to June 30, 1959 .

4. The percentage of calcium, potassium, magnesium, and sodium at six locations within mature watermelon plants, $1958 \ldots . . . . . .33$

5. Test of significance for the percentage of potassium, calcium, and magnesium at $\mathbf{s i x}$ locations within mature watermelon plants. . 34

6. The effects of caloium treatments on the dry welght of vines, roots, fruits, and total weight in the greenhouse experiment . . . 42

7. The effects of calcium treatments on flower production and fruit set in the greenhouse experiment ..................

8. Test of significance for the effects of calcium treatments on flower production in the greenhouse experiment ..........

9. The effects of calcium treatmentg on the percentage of calcium, potasstum, and magnesium in the leaves and tips of plants grown in the greenhouse ...............

10. The eifects of calcium treatments on the percentage of calcium, potassium, and magnesium in the roots and fruits of plants grown in the greenhouse

11. The $\mathrm{pH}$ and pounds per acre of available nutrients of samples taken from the watermelon beds on April 1, 1959 
12. The $p$ H and pounds per acre of available uutrients of samples taken from each side of the melon beds on Apri1 1, 1959 ......

13. The influence of more than elght inches of rainfall on the removal of fertilizer nutrients in pounds per acre from the upper eight inches of soll in watermelon beds .........................

14. The effects of calcium and nitrogen on early vine growth as indicated by the dry weight of elght hills per plot

15. The effects of calclum and nitrogen on the number of early U. S. Number 1 watermelons.

16. Effects of calcium and nitrogen on the total welght in pounds of early J. S. Number 1 watermelons. . . . . . . . . . . . .

17. Effects of calcium and nitrogen on the total number of U. S. Number 1 watermelons . . .

18. Erfects of calcium and nitrogen on the total weight in pounds of 0 . S. Number 1 watermelons. ...................

19. The effects of calcium and nitrogen on the average soluble solids as per cent sucrose from all marketable melons per plot ...

20. The effects of calcium and nitrogen on the average thickness of the rind in cent1meters at the top center and bottom center of all marketable fruits............

21. The offects of calclum and nitrogen on the average thickness of the rind in cent1meters at the blossom-end of all marketable

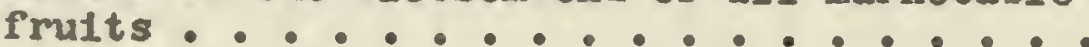

22. The effects of calcium and nitrogen on the percentage of blossom-end rot .......

23. The effects of calcium and nitrogen on the total number of frutts set..........

24. The effects of calcium and nitrogen on the percentage of calcium, potassium, and magnesium in the tips of young watermelon plants... 
25. The effects of calcium and nitrogen on the percentage of calcium, potassium, and magnesium in the leaves of young watermelon plants ....................

26. The effects of calcium and nitrogen on the percentage of calcium, potassium, and magnesium in the tips of mature watermelon plants ...................

27. The effects of calcium and nitrogen on the percontage of calclum, potassium, and magnesium in the leaves of mature watermelon plants ....................

28. The effects of calcium and nitrogen on the percentage of calclum, potasstum, and magnestum in U. S. Number 1 waternelon fruits. 65

29. The effects of calcium and nitrogen on the percentage of calcium, potassium, and magnesium in watermelon fruits exhibiting blossom-end rot

30. The average percentage of calcium, potasaium, and magnesium assoclated with each calclum and each nitrogen level in both vines and fruits from the field experiment . . . 80

31. The pH and the pounds per acre of avallable nutrients from soli samples taken in watemelon beds from all field plots on Apr11 1, 1959 ............ 98

32. The $\mathrm{pH}$ and the pounds per acre of available nutrlents from soll samples taken on each. side of the bed from all plots on April 1 , 1959 


\section{LIST OF ILLUSTRATIONS}

Figure

Page

1. The twelfth leaf from the base of the plants in treatments $2,3,4,7$, and 8 from the greenhouse experiment ..........

2. Representative root systems from treatments

$2,3,5,7$, and 8 of the greenhouse

experiment. . . . . . . . . . . .

3. The interaction of calcium and nitrogen

$\left(\mathrm{Ca}_{L} \mathrm{X} \mathrm{N}_{L}\right)$ on the magnesium content of

the leaves of young watermelon plants ...

4. The interaction of calcium and nitrogen

$\left(\mathrm{Ca}_{0} \mathrm{X} \mathrm{N}_{\mathrm{Q}}\right)$ on the potassium content of

D. S. Number 1 watermelons ........

5. The interaction of calcium and nitrogen

$\left(\mathrm{Ca}_{L} \times \mathrm{N}_{\Omega}\right)$ on the potassium content of

watermelon fruits exhlbiting biossom-

end rot...................

6. The interaction of calcium and nitrogen

$\left(\mathrm{Ca}_{L} \times \mathrm{N}_{L}\right)$ on the magnesium content of

watermelon fruits exhibiting blossom-

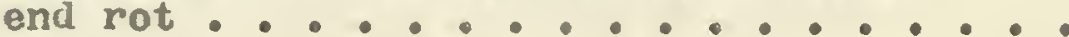

7. The influence of calctum on the dry welght of fruits, roots, vines, and total welght per experimental unit in the greenhouse....

8. The percentage increase in early and total yield of U.S. Number I watomnelons from plots receiving 500 and 1,000 pounds of hydrated Ilme over plots recelving no Ilme ................... 


\section{INTRODUCTION}

The watermelon is one of the most extensively grown vegetables in the United Statos, yot little is known about the nutrition of this plant. Florida alone produced 95,000 acres of watermelons during the 1957 and the 1958 seasons, which comprised 31 per cent of the southern acreage or 21 per cent of the acreage of the United States (80). Relatively few basio nutrient experiments have been conducted with watermelons, mainly because the extensive type of vine growth limits the feasibility of greenhouse culture techniques. However, extensive experimentation has been conducted in the fleld on the rates, sources, and mothods of application of the major rertilizer elements.

In the South watermelons are planted on l1ght sandy so11s, whicil often have inherently low calcium supplies and pH. Watermelons have generally been considered to tolerate relatively acld conditions, and thus the liming of watermelon fields is not normally a recommended practice. However, from a literature review, It is obvious that very little research has been conducted on the effects of differential calclum levels and soll pH on the jleld and quallty of watermelons.

The objective of this study was to evaluate the effects of the calclum supply on growth responses; yleld; 
quality; sex expression and fruit set; and the concentrations of calclum, potassium, and magnesium in the tissues of the Charleston Gray varlety of watermelon. The study was conducted in two parts: (1) a greenhouse phase involving elght calcium levels in nutrient cultures and (2) a field phase designed to study three levels of calcium in combination with three levels of nitrogen.

The results of this study may be beneficial in explaining the occurrence of certain physiological disorders and poor ylelds often obtained from watermelon fields recolving apparently adequate fertilizer. It also emphasizes the need for additional research on the nutrition of the watermelon. 


\section{REVIEW OF LITERATURE}

\section{Mineral Nutrition of Cucurbits}

Erfects on yeld

The extent to which the major nutrient elements affect the yield of watermelons (C1trullus nulcaris Schrad.) is variable, depending upon the element, the environment, and the chemical properties of the soll. Hartwell and Damon (34) reported in 1914 that the best $y 101 \mathrm{ds}$ of watermelons were obtained on plots made very acid by the application of sulfate of ammonia. Examination of their data indicated that liming had no effeot on yield. Hartman and Gaylord (33) reported no significant difference in yield or average weight of watermelons grown on Princeton or Elk fine sand ranging in $\mathrm{pH}$ from 4.7 to 7.5 . However, there was a trend toward greator yields at the higher $\mathrm{pH}$ levels. The $\mathrm{pH}$ range was obtained by the application of up to 1,000 pounds of elemental sulfur or up to 9,000 pounds of limestone.

Hall, Nettles, and Dennison (28) found no significant differences in yields in a factorial experiment on Arredonda fine sand containing three levels of calclum $(0,80$, and 160 pounds per acre supplied as calcium sulfate in the row) and three levels of magnesium $(0,20$, and 40 pounds per acre of magnesium oxtde applied in the row). Hall, Nettles, and Dennison (29) In later work were unable to show benefits from 
the application of gypsum alone in the row. Jamison and Nettles (40) reported that the application of soluble magnesium with all Inorganic nitrogen increased the jields of watermelons.

Elsenmenger and Kucinski (20) observed that calcium hastened maturity of both watermelons and cantaloupes by nearly two woeks over no-lime treatments. Apparentiy the application of lime augments cantaloupe production on solis with low pH. Carolus and Lorenz (14) concluded that the application of lime to light acta solls promotes early maturity and increases ylelds of rnuskmelons. Hartman and Gaylord (32) obtained an Increase of cantaloupes from 160 bushels to 350 bushels per acre by increasing the soil pH from 4.7 to 7.2 with Iimestone. Other cucurbits Including cucumbers, squash, and pumpkins apparently yield more when grown on solls moderately supplied with calcium and within the pll range of 5.5 to $7.0(42,83)$.

Considerable research relative to the effect of $N-P-K$ fertlilzers on ylelds has been reported. Hall, Nettles, and Dennison (29) concluded after five yoars of experimentation at several locations in Florlda that 60 pounds per acre each of potassium and nitrogen were ample to give maximum ylelds In seasons with reasonably favorable ralnfall. This is, in general, supported by data presented by Nettles and Halsey(53) in 1958. Bradley and Fleming (10) observed similar results on Norfolk fine sand in Arkansas. They stated that 60 pounds 
each of nitrogen, potassium, and phosphorus was adequate for good ylelds. In a somewhat drier area in Texas, Smith and Nohr (70) concluded after four years tests on Hockley fine sand that 20 pounds of nitrogen, 40 pounds of phosphorus, and 40 pounds of potassium produced nazimum ylelds. However, Patterson and Smith (57) reported significant increases in yield from up to 200 pounds of potassium on Hockley fine sand in Texas. According to Brantley (11) nitrogen increasad early marketable, total marketable, and total yleld of watermelons in Indiana on Princeton fine sand in a season of heavy rainfall but not in a moderately dry season. Potassium did not affect yields in elther season.

\section{Effocts on guality}

It has long been known that the quality of watermelons, especially tho soluble solids, is influenced by both heredity and envirommental factors $(60,85)$. The offects of these factors have been established; however, research relative to the true influence of different nutrient elements is less apparent. Hartman and Gaylord (33) reported that the application of up to 9,000 pounds of ground limestone did not significantly increase the percentage of sucrose. Hall, Nettles, and Donnison (28, 29) observed that neither calcium sulfate nor magnesium oxide had any significant effect on the percentage of soluble solids, hollow-heart, or white-heart. However, Eisenmenger and Kucinsk1 (20) stated that cantaloupes and watemelons grown on land treated with calcium were considerably higher 
In sugar content, although no data were presented. Mazaeva (47) observed that magnesium Increased the sugar content of Watermelons grown in pots of 11ght sodpodzol1zed soll. According to Morazor (52) the application of sodium chloride or sodiue sulfate to the soll decreased the monosaccharides and the total sugar content of both watermelons and muskmolons.

Work by Brantiey (11) and by Kimbrough (41) Indicated that up to 250 pounds of elemental nitrogen had no signir1cant effect on the percentage of soluble solids in watermelons. Bradloy and Fleming (10) reported a significant increase in soluble solids as a result of an interaction between nitrogen and phosphorus and an interaction between phosphorus and potassium, but other quality measuremonts such as hollow-heart, white-heart, and rind thickmess were not affected by any certilizer treatment. When yields were not affected by fertilizer treatments, soluble solids were not affected; therefore, they concluded that providing adequate fertilizer assures good qualitg. In contrast to this, Hall. Nettles, and Dennison (28) consluded after several experiments that naitber potassium nor nitrogen had any significant effeot on soluble solids, white-heart, or hollow-heart. Brantiey (11) found no effect from differential levols of potassium on the quality of watermelons or cautaloupes. Hoodard (85) demonstrated that tise occurrence of white-heart of watermelons was assoclated with heredity and not with nitrogen source. 
Efrects on sex expression and frutt set

The nature of the effect, If any, of the cations on sex expression and fruit set has not been clearly defined. Hasler and Maurizio (35) reported that insufficlent amounts of potassium as well as nitrogen and phosphorus resulted in both poor flowering and seed set in winter rape (Brassica napus). According to Mazaeva (47), magnestum acts on reproductive organs, tending to increase fomale flowers in many crops. Stark and Haut (72) found that flower production in cantaloupes was inbibited when the potassium level was dropped to 0.25 milliequivalents per liter $(9.15 \mathrm{ppm})$. There was a positive response of fruit set to high levels of calclum: 10 and 15 milliequivalents per liter $(200,300$ ppm.. A concentration of 0.2 milliequivalents per liter (2.4 ppm) of magnesium was inadequate for normal frult set. After comprehensive literature reviews on the physlological aspects of sex expression, Loehwing (45) and Heslop (36) concluded that, with the exception of carbohydrates and nitrogen, general nutrition is not a major factor in sex expression in monoeclous and dioecious species. Furthermore, Loehwing (45) stated that highly localized compositional differences are much more significant than general composition, not only in relation to flowering but also in determining sexes in various floral parts.

There are numerous reports in the literature to the effect that increased nitrogen concentrations in the substrate 
enhanced female sex expression in plants. Thompson (76) working with spinach, Tibeau (77) with hemp, and Sabinin (64) with corn observed that high levels of nitrogen stimulated the production of pistillate flowers whlle low nitrogen levels favored staminate flower formation. Stmilar observations have been reported by T1edjens (78) and Dearborn (18) for cucumbers (Cucumis gativus), by Hall (30) for gherkins (Cucumis angurta), by Sabinin (64) and Minina (51) for cucumbers and watermelons, and by Brantley (11) for cantaloupes and watermelons.

The influence of nitrogen on fruit set is similar to Its effect on yields. In general, increasing increments of nitrogen up to a critical maximum enhances fruit set while additional increments tend to decrease fruit set (11, 17). Work by Jamison and Nettles (40) and by Cunningham (17) Ind1cates that late side-dressing with nitrogen delays and decreases fruit set.

Effects on blossom-end ret

The precise cause of watermelon blossom-end rot has not been determined. Blossom-end rot first appears as a water-soaked area at the blossom-end, later turning brown, and often invaded by saprophytic and parasitic fungl (56, 73). The disease has been attributed to many factors--includIng pathogenio organisms, disarrangement of internal nutrition, Improper molsture supply, poor pollination and/or fert1lization. Pathologists (56, 75) have shown that a large number 
of both saprophytic and parasitic organisms have been as80clated with blossom-end rot. Parris (56) reported that Brthlum debaryanum and P. aphanidermatum started the infection. Taubenhaus (75) in 1921 concluded that Diplodia tubericola caused blossom-end rot of watermelons. However, Blodgett (8) was unable to control the disease by use of funglcides.

Stuckey (73) postulated in 1924 that blossom-end rot is probably a physiological disturbance brought on by rapid changes in 8011 moisture as the young fruit start to grow. He reported it is of little consequence in low-lying loamy sands where the water table is near the surface. Walker (82) In 1931 noted that blossom-end rot had been observed in connection with pollination work and that defective pollination appeared to be the most important factor in initiating it. He pointed out that considerable decline of the melon occurred before fungl appeared. Nettles and Halsey (53) were unable to associate the incidence of blossom-end rot with fertilizer rates of up to 2,000 pounds of $6-8-8$ or with plant spacings of 3, 6, 9, and 12 feet. Everett and Geraldson (22) obtained a lower percentage of melons exhibiting blossom-end rot from plots receiving one-half ton of hydrated lime or gypsum per acre plus two tons of dolomite than from plots recelving dolomite alone.

Geraldson (27) has shown similar blossom-end disorders in tomatoes and peppers may bo produced by insurficient calcium in the substrate or by high concentrations of soluble salts. Taylor and Smith (74) reported significant increases 
in blossom-end rot of tomatoes as a result of high nitrogen levels.

Brantley (II) associated the occurrence of blossomend rot of watermelons with high nitrogen levels; however, no data were presented.

Calcium in Plant Nutrition

Role in the soll

Soll scientists have vividly demonstrated that the application of lime affects not only the chemical properties of the soll but also the biological and physical properties as well. The beneficial chemical effects of liming acid soils result from: (1) Increased avallability of calcium and possibly certain other nutrient elements and (2) pH changes which influence the solubility of other elements, both essential and non-essential.

In work reported by Marshall (46) a considerable part of the absorbed calcium in kaolinitic type clays became active at calctur saturation percentages of 39 to 59 while 70 to 80 per cent calcium saturation was necessary in montmorillonitic type clays. According to Sharples and Foster (66) maximum growth of cantaloupes on Ar1zona desert soil occurred between 50 to 60 per cent calcium saturation with growth decreasing rapidy on elther side of this range. Fried and Peech (25) in several field and greenhouse experiments have demonstrated that increasing the calcium supply with gypsum, in contrast to Iimestone, failed to increase plant growth of such crops 
as barley, alfalfa, and perennial ryegrass.

Many workers have shown that the golubility of aluminum, manganese, iron, boron, copper, and zinc increases with increasing acidity $(25,38,61,65,71,86)$. Toxic concentrations of such elements as aluminum, manganese, and iron may develop below pH 5.5; moreover, such elements as manganese, Iron, and boron may bocomo deficient above pH 6.5 .

The soll blological population is influenced by calcium directly as an essential element for metabolism and indirectly through alterations in the 8011 reaction ( 1,4 , 13, 83). Microbiologists have demonstrated that, in general, fungl thrive when the pH 18 below 6 and bacterla and act1nomycetes prefer media above pII $6(1,13,48,81)$. This points out the necessity for liming acid solls to obtain maximum benefits from nitrifying bacteria as well as from other biological processes involving principally bacteria. Baver and Hall (5) and Meyers (49) have shown that calcium lons do not affect the physical properties of organic or inorganic collolds any more than do hydrogen lons. After reviewing the literature on this subject Baver (4) concluded the main effect of Ilme on the soll physical properties, especially aggregation, resulted indirectly from its effect on the production and decomposition of organic matter.

\section{Role in plants}

Calcium enters into several important physiological processes within the plant. One of 1 ts most important roles 
is the reaction with pectic acids to form calcium pectate, a constituent of the middle lamella of the cell wall (9, 48, 50). Pectic acid is composed of long chains of galacturonic acid residues which possess the 6-membered pjranose ring structure with a carboxyl group on the number five carbon. This carboxyl group is free to combine with avallable cations such as calcium, potassium, and magnesium thereby forming pectates.

Calcium reacts with certain organic acids, especially oxalic and malic, to form relatively immobile oxalate compounds $(6,9,79)$. According to Meyer and Anderson (48) these oxalate compounds occur in the cell vacuoles in large quantities.

Plant physiologists point out that 1 was once believed that organic acids were toxic; therefore, calcium and other cations were absorbed to precipitate these acids. However, according to Meyer and Anderson (48) and Shear, Crane, and Meyers (68) cell sap must be electrostatically neutral; therefore, if greater absorption of cations than anion occurs the plant cells produce certain organic acids to precipitate the cations.

Nightingale (54) reported that in the absence of calclum some species are unable to absorb nitrates.

It is generally belleve that calcium is necessary for the continued growth of merlstematic t1ssue. Th1s is apparent by the symptoms of calclum deficient plants. The leaves of plants grown in media low in calcium, especially the 
young leaves, often are distorted, dark green in color, and the margins pointed downward or cupped under $(48,50)$. In severe cases a deficiency is manifested by cessation of terminal growth and the development of chlorosis and necrotic areas even in the older growth.

Calcium plays another important rolo in plant growth by its antagnostic effects on the absorption of other Ions (21, 44, 48, 50,56, 79). The antagonism apparently works In at least two ways. First, less toxic lons may depress the uptake or accumulation of more toxic lons. For example, sodium, potassium, or magnesium may be toxic in single-salt solutions; however, this toxic effect is eliminated by the addition of calcium. Second, proteins may become saturated with a single salt thereby changing their normal composition. The addition of other salts tends to balance the protein colloldal system.

\section{Cations in Plant Tfssue}

\section{Cation accumulation}

It has been demonstrated many times that the concentration and type of nutrient elements occurring in plant tissue is dependent upon a number of interrelated environmental conditions as well as the plant species in question. Numerous ilterature reviews point out that the ratio or balance of the various lons in the substrate has a direct effect on tho chemical composition of the tissue $(6,13,21,63,65,74)$. In a refinement and extension of nutritional theories proposed 
by earlier workers, Shear and co-workers $(67,68,69)$ state that plant growth is a function of two nutritional variables, intensity and balance, which are reflected in the composition of leaves when the plants are in the same stage of growth and development. Intensity refers to the total equivalent concentration of all functional nutrient elements in the plant. They pointed out that there is a definite cation: anion ratio within the plant; therefore, an accumulation of one or more cations must be accompanied by an equiralent decrease in one or more cations at any given anion level. Likewise, an accumulation of one or more anions at a given cation level must be accompanied by a decrease in one or more anions. The simultaneous accumulation of both cations and anions, elther organic or inorganic, in plant tissue has been observed by many authors $(3,13,26,63,68,69,79)$.

Cooper (16) concluded that the relative rate of absorption and accumulation of nutrients by plants is proportional to the relative activity (energy properties) of the nutrients as measured by such means as standard electrode or ionization potential. This conclusion has been subjected to extensive criticism. Geraldson (27) explatned the occurrence of blossom-end rot of tomatoes as a calcium deficiency when the plants were grown in high concentrations of soluble salts on the basis that as the soluble salt concentrations increase, the relative activities (effective concentration) of the divalent salts decrease at a more rapid rate than monovalent salts. Also, the calcium to soll soluble salts ratio (actual 
concentration) varies inversely with concentration.

Shear, Crane, and Meyers (69) working with young, tung nut trees found that increasing the magnesium or potasslum in the oubstrate generally resulted in increased concentrations in the tissue; however, the total accumulation of potassium+magnestum+calclum was generally decreased. Moreover, increasing calclum in the substrate not only increased the calctum in the tissue but also increased the total accumulation of the three cations. Th1s was explatned on the basis that since a large percentage of the absorbed calcium in many species is inactivated by oxalate precipitation and no longer able to affect the entrance of other cations, the increased calcium accumulation would result in an increasod total cation accumulation. Plerre and Bower (59) pointed out that potassium absorption $1 \mathrm{~s}$ usualiy decreased in the presence of high concentrations of other cations such as calcium and magnestum. However, under relatively high levels of potasalum, increasing the concentration of other cations, especially calcium, may increase potaselum absorption and accumulation in many crops. After a critical literature review Peech and Bradfleld (58) concluded that the addition of lime to 8011 s may have no effect, may increase, or decrease the avallability of potassium to plants depending upon the degree of inftial soll saturation. They indicated that calcium may have little effect on the absorption of the avallable potassium, at least at the concentrations found in most so118. Meanwhile, Geraldson (26) indicated that the 
application of excessive amounts of amonium, potassium, magnesium, or sodium to sandy soils of Florida limited the uptake of calcium by tomatoes.

Reports on the specific cation nutrition of cucurbits, especially watermelons, are limited. Bradley and Fleming (10) observed that the potassium content of watermelon leaves was influenced primarily by the addition of potassium to the so11. The difference in potassium content of the leaves botween treatments grew smaller as the season progressed. The application of 60 pounds of potassium in the row significantly reduced the calcium content of the watermelon leaves early in the season but had no effect toward the end of the season. In one of two seasons potassium applications significantly roduced the magnesium content of the leaves early in the season but had no effect on samples collected toward the end of the growing season.

Sharples and Foster (66) grew cantaloupes in Artzona desert sand cultures with calcium saturation percentages of $2.9,11.9,36.2,63.7,72.5$, and 86.6. They found that extremely high and low aturation percentages tended to restrict potassium uptake while leaf calcium varied directly and magnestum inversely with the calcium saturation percentages. Stark and Haut (72) reported that the calcium content of cantaloupe leaves increased in a geometric proportion to the calcium concentration in the substrate, while potassium and magnesium increased in aritbmetic proportions to the concentration of these respective elements in the substrate. 
Concentrations of 4 to 5 milliequivalents por liter (200$300 \mathrm{ppm}$ ) appeared to produce the best growth. When calcium was supplied at 4,8 , or 16 milliequivalents $(80,160,220$ ppm), Reynolds and Stark (62) obtained maximum top, root, and fruit ylelds of cucumbers at the lowest calclum level, and growth decreased as the calcium level increased.

Effects of nitrogen on the cation content

It has ween established that not only the concentration of nitrogen in the substrate but also the source (nitrate or ammoritum) will have a profound effect on the cation content of the tissue $(3,13,48,63,67,84)$.

It has been shown repeatedly that increasing the proportion of nitrate to ammonium nitrogen in the substrate Increases the production of organic acids, especially oxalic (13). Since oxalic acid precipitates much of the absorbed calcium, plants growing under high nitrate levels may ut1$11 z e$ more calcium $(3,13,48,63,67,68)$.

Shear and co-workers $(67,68,69)$, Geraldson (26), and Burrus (13) pointed out that the activity of the ammonium Ion 18 very similar to the activity of the potassium ion and will greatiy affect the uptake of other cations. Shear and Crane (67), by supplying the nitrogen as ammonium in contrast to nitrate, reduced the cation content of tung leaves by the following percentages: potassium--18 per cent, magnesium-25 per cent, and calclum--46 per cent.

Bradley and Fleming (10) Indicatea that the soll 
application of ammonium nitrate had no consiatent effoct on the potassium, calcium, and magnesium content of watermeion leaves. Sharples and Foster (66) reported that the application of ammonium nitrate in sand cultures of cantaloupes significantly increased the potassium, calcium, and magnesium content of the leaves and decreased the phosphorus content under varying calcium and bagnesium ratios.

\section{Distribution of cations in plants}

Numerous studies have been conducted on the distribution of cations in plant tissue employing both chemtcal analyses and radio-isotopes $(3,7,31,43,63)$. The followIng generalizations may be drawn: (I) a large part of the calcium is located in the leaves with considerably smaller amounts occurring in the roots, stem, seods, and meristematic areas, (2) potassium is distributed more uniformly throughout the plant than calcium with relatively large quantities occurring in regions of meristematic division, translocation, and storage, and (3) magnosium is prosent in somewhat smalier amounts than calcium or potassium with relatively large concentrations occurring in the leaves and In the seeds of some plants.

Hardh (31) showed with radiographs that calcium accumulates in cucumbers in clearly separated pits occurring more frequently in the leaves than in the stems. Wilkins (83) reported that cucurbit vines, namely, pumpkins, preserving c1trons, two types of squash, cucumbers, and canta1oupes, contained large amounts of calclum ranging from 5 
to 8.5 per cent calcium oxide, while the fruits at no time contalned over 0.75 per cent calclum oxide. The vines contained up to 5.9 per cent potassium oxide and the fruit up to 5.4 per cent depending upon the species. The magnesium content of the vines was much less variable, ranging from 0.46 per cent to 1.30 per cent magnesium oxide, and the frult consistently contained even less ragnesium than calcium. Wilkins (83) also found an increase in the percentage of calcium in the cucurbit vines toward maturity, and the calclum content of the fruit decreased slightly towurd maturity. The opposite trends were true for both potassium and magnesium. 


\section{METHODS AND PROCEDURES}

The watermelon Industry in North Central Florlda was surveyed by making field observations and soil analyses in 30 melon fields during the 1958 growing season. This alded in familiarization with the fertility problems involved in watermelon production.

The Iiterature indicated that certain physlological disorders of watemelons resulted from adverse chenical or physical conditions of the soll. Therefore, profile examinations were made and soil samples were obtained from plots devoted to watermelon fertility experimants as described by Nettles and Halsey (53) in the spring of 1953. Chemlcal analyses of the soll samples were made to observe any possible correlation between the chemical constituents and the presence of blossom-end rot.

In the spring of 1958 samples of watormelon tissue were obtained from mature fleld-grown plants to determine the distribution of calcium, potassium, magnesium, and sodium in the various plant parts and the variation of these elements from plant to plant. The samples for analyses were taken from $81 x$ plants grown under similar onvironmental conditions and wore bearing mature fruits. Samples for analyaes from each plant included the following locations: basal leaves, mid-leaves, vine t1ps, basal stem, mid-stem, and frult. 
Each t1ssue sample was analyzed for calcium, potassium, magnestum, and sodium on the Beckman model DU flame spectrophotometer by using procedures outlined by Breland (12). In order to evaluate the effect of interfering anions in the watermelon tigsue on the calcium determinations, each sample was analyzed for calclum, with and without these lons present. The method of removing the interfering anions from the samples is given under the heading "Chemical Analyses." Preliminary experiments with nutrient solutions and quartz sand were conducted to determine the feasibility of these techniques for greenhouse culture of watermelons. In addition to the major study reported below, simultaneous exploratory work was conducted in the greenhouse and fleld to observe the effects of follar applications of calcium chloride on watermelons. Plants grown in field soll in greenhouse benches wore sprayed with $0.25,0.10,0.08$, 0.06 , and 0.04 molar concentrations of calclum chloride to determine optimum levels for follar applications. Severe leaf burning occurred at the 0.25 level and slight burning was evident at the $0.10 \mathrm{molar}$ concentration. The 0.04 through 0.08 molar levels appeared satisfactory for treatment. A greenhouse sand culture experiment with 8 replications was established to observe the effects of bi-weekly applications of 0.04 molar calctum chloride spray versus no spray on the watermelon plants. Adequate amounts of a basic nutrient solution containing $16 \mathrm{ppm}$ calclum was supplied to each pot. A field exporiment containing threo levels of a calcium chloride 
follar spray arranged in a randomized block design was conducted during the 1959 season. The spray levels were no spray, 0.04, and 0.08 molar concentrations of calcium chloride applied every f'lve days.

The major study consisted of two parts-ma greenhouse phase and a fleld phase. The greenhouse phase was organized to study the effects of various calcium levels in nutrient solutions on growth responses; sex expression; frutt set and qualty; and the ccumulation of calcium, potassium, and magnesium in the various plant parts. The field phase was designed to investigate the effects of three levels of nitro.. gen and three levels of calcium on growth, yield, quality,

and cation composition of the watermelon plant. The Charleston Gray variety of watermelons was used in all experimonts.

\section{Greenhouse Phase}

A randomized block experiment with four replioations was Initiated on April 15, 1959, to study the influence of elght progressive levels of calctum on watermelon responses. This test was conducted using a solution culture procedure In which the calcium levels were supplied by the addition of calclum chloride to a basic nutrient solution. Young watermelon seedlings were produced by germinating seeds on wet f1lter paper. Two of these seedlings constituted an experimental unit when suspended by a wooden support in a fourgallon glazed crock. The solution levels in the crooks were maintained at 13 liters by daily application of delonized 
water with a complete change of solution each week. Adequate aerition was supplied to each crock by means of a centrally located pump.

The concentration of calcium in the different treatments is given in Table 1 . Since 1 t was necessary to use large volumes of solutions, the concentration $18 \mathrm{gtven}$ in both parts per million(ppm) and milliequivalents per liter $($ m.e./L).

\section{TABLE 1}

CALCIUM LEVELS IN GREENHOUSE SOLUTION CULTURES

\begin{tabular}{ccc}
$\begin{array}{c}\text { Greenhouse Treatient } \\
\text { Number }\end{array}$ & $\begin{array}{c}\text { Calcium } \\
\text { ppm }\end{array}$ & $\begin{array}{c}\text { Calclum } \\
\text { m.e./L }\end{array}$ \\
\hline 1 & 0 & 0.0 \\
2 & 4 & 0.2 \\
3 & 8 & 0.4 \\
4 & 16 & 0.8 \\
5 & 32 & 1.6 \\
6 & 64 & 3.2 \\
7 & 128 & 6.4 \\
8 & 256 & 12.8 \\
\hline
\end{tabular}

The composition of the basic nutrient solution is shown in Table 2. The Iron solution was prepared by dissolving 100 grams of sodium-iron versenol (12 per cent iron) per 2.5 11ters of delonized water, and $1 / 10$ millileter of this solution was used per liter of nutrient solution. The other elements were prepared by the procedure outlined by Hoagland and Arnon (37).

The pH of all newly prepared solutions, regardless of calclum level, was approximately 5.2. At the end of the 
seven-day period the $\mathrm{pH}$ of the solutions ranged from 6.0 to 6.8 depending on the size of the vines; therefore, no pH adjustments were nocessary.

TABLE 2

THE COMPOSITION OF THE BASIC NUTRIENT SOLUTION FOR GREENHOUSE EXPERTMTNT

\begin{tabular}{llc}
\hline Element & Source & $\begin{array}{c}\text { Concentration } \\
\text { (ppm) }\end{array}$ \\
\hline Nitrogen & $\mathrm{KNO}_{3}$ & 70 \\
Phosphoms & $\mathrm{KH}_{2} \mathrm{PO}_{4}$ & 32 \\
Potassium & $\mathrm{KNO}_{3} \mathrm{KH}_{2} \mathrm{FO}_{4}$ & 234 \\
Magnesium & $\mathrm{MgSO}_{4}$ & 48 \\
Boron & $\mathrm{H}_{3} \mathrm{BO}_{3}$ & 0.5 \\
Manganese & $\mathrm{MnCl}_{2}$ & 0.5 \\
Iron & $\mathrm{NaFeH}_{\text {Mat }}$ & 0.5 \\
Molybdium & $\mathrm{H}_{2 \mathrm{MOO}_{4}}$ & 0.05 \\
Copper & $\mathrm{ZnSO}_{4}$ & 0.05 \\
\hline
\end{tabular}

Fifteen days after transplanting one plant per pot was harvested and dry weights were obtained as an early growth measurement. All flowers were hand-pollinated in the early morning and the number of both pistillate and staminate flowers produced per experimental unit was rocorded daily. All fruits developed blossom-end rot in this experiment and were harvested individually and oven-dried as soon as the rot was obvious. Continuous records on growth responses were maintalned throughout the experiments.

The experiment ended June 15 and the following obtained from each experinental unit: leaf, tip, and root samples and dry welght of frui, roots, and vines. The leaf 
samples were composed of eight mature leaves per plant. The tip samples were composed of elght actively growing lateral tips two inches in length. The root samples were composed of the entire root system from each experimental unit. All tissue samples wore washed twice in delonized water before drylng, with each washing lasting approximately 10 seconds.

\section{Fteld Phase}

Description of soil type and soll test

The area used in this experiment was located on the Horticulture Unit of the University of Florida near Gainesville, Florida. The 8011 was classifled as Kanapaha Pine sand (2). The surface layer 1 s medium gray, loose, actd, fine sand and underlatn by yellowish white, loose, strongly acid, fine sand. This is underlain by a phosphatic Iimo material. Kanapaha fine sand is relatively low In organic matter, moderately to imperfectly drained, level to alightly undulating with poor physical stmeture, and often located near ponds or lakes.

Two soll samples were taken from each plot on April 1. One sample was taken in the bed and conslsted of 5 cores taken at four locations across the bed. The other sample was taken from the calcium-treated area on each side of the bed and consisted of 20 cores. The samples were analyzed for avallable $\mathrm{CaO}, \mathrm{MgO}, \mathrm{K}_{2} \mathrm{O}, \mathrm{P}_{2} \mathrm{O}_{5}, \mathrm{NO}_{3}$, and pII by the University of Florida Soll Testing Laboratory. 
Field methods

As experiment containing three levels of calcium and three levels of nitrogen arranged factorially in a balancedlattice design was conducted in the spring of 1959 on Kanapaha fine sand. The calcium levels tested were at the rate of 0,500 , and 1,000 pounds of hydrated Iime $\left(\mathrm{Ca}_{2}(\mathrm{OH})_{2}\right)$ per acre. The nitrogen levels tegted were at the rate of 60,120 , and 180 pounds per acre applied as amonium nitrate. The individual plot size was 15 by 80 feet with each calciusa treatment being broadcast in a 10-foot band throughout the length of each plot on February 20. This left an untreated area of 2.5 feet on both sides of each plot. An untreated area or 10 feet was left between the ends of the plots to serve as a buffer area.

A single bed approximately 8 inches high and 18 inches wide was prepared in the center of each plot. One half of the total nitrogen and a uniform application of 80 pounds of $\mathrm{P}_{2} \mathrm{O}_{5}$ and 80 pounds of $\mathrm{K}_{2} \mathrm{O}$ per acre was placed in two bands in the row on March 12. The remalning half of the nitrogen was plowed Into both sides of the bed May 1, when the vines began to develop.

Sixteen hills of watermelons were planted per plot on March 26, and an excellent stand of plants was obtalned. Two weoks after omergence the melons wore thinned to two plants per hill. The methods used for cultivation, insect, and disease control were in aconrance with recommended practices for the North Central Florida area. The melons were 
harvested four times (June 17, 22, 26, and July 3) and the following data obtalned on all frults from each plot: number and weight of early marketable yield; number and weight of total marketable yield; mean thickness of rind of each fruit measured at the top center and bottom center; thickness of rind at blossom-end; percentage soluble sollds; percentage blossom-end rot; and cutting quality including data on hollowbeart, white-heart, and other abnormalities. The first three harvests were consldered to represent the early yleld, and all normally shaped melons over 16 pounds in welght were considered as U.S. number 1. Soluble solids wero determined on a Carl Zelss water-cooled refractometer.

The amount of rainfall recorded in the immediate area of the experiment is presented in Table 3 .

\section{TABLE 3}

TOTAL BI-MONTHLY RAINFALL RECORDED. AT THE BORTICULTURE UNIT MARCH 1 TO JUNE 30, 1959

March 1-14

March 15-31

April 1-14

April 15-30

May 1-14

May 15-31

June 1-14

June 15-30

1.73

2.07

0.70

5.93

1.53

2.32

Total 
Since there was an extremely large amount of rainfall following the first fertllizer application early in March, an attempt was made to estimate the fertilizer loss from the upper 8 inches of soll as a result of more than 8 Inches of rain. An extra row was fertilized on April 1 at the rate of 90 pounds of nitrogen and 80 pounds each of $\mathrm{P}_{2} \mathrm{O}_{5}$ and $\mathrm{K}_{2} \mathrm{O}$ per acre. This was located beside a row which recelved the same fertilizer treatments before the rains. S1x cotl samples were taken on April 1 from each of these two rows, as well as from a third row recelving no fertilizer, and analyzed for $\mathrm{CaO}, \mathrm{MgO}, \mathrm{P}_{2} \mathrm{O}_{5}, \mathrm{~K}_{2} \mathrm{O}, \mathrm{NO}_{3}$, and $\mathrm{pH}$.

\section{Tissue samples}

On May 1, Just prior to the second application of nitrogen, every other hill of the young watermelon plants from each plot was harvested and pooled into one composite sample, and the oven-dry welght was obtained. Prior to dry1ng, tip and leaf samples were taken from each composite sample for chemical analyses. Additional leaf and tip samples were obtained from each plot for chemical analyses one week prior to the first harvest of frult. At this time the plants were in a vigorous state of growth with little apparent disease or insect damage. The leaf sample from each plot was composed of the first two normal leaves, Including the petiole, from each plant. The tip samples consisted of four actively growing vine tips from each plant located in each plot. These tips were 2 inches in length and included 
very young leaves and a smali end portion of the stem. The leaf and tip samples were oven-dried and stored.

The fruits exhibiting blossom-end rot were removed from the vines at the beginning of the harvest period and a composite frult sample was obtained from six representative fruit: from each plot. Three cores, one inch in diameter, were taken through the center of each frult by use of a soll sampling tube. These cores were then cut into sections one-half inch long and mixed thoroughly; after which, four 90-gram subsamples were welghed from each plot sample. Two of these were frozen at $0^{\circ} \mathrm{F}$. for subsequent chemical analyses. The remaining two samples were used for molsture determinations. Similar subsamples for analyses were obtained from the first $s 1 x$ normal fruits harvested from each plot.

\section{Chemical Analyses}

All tissue samples were dried in a forced air oven for 48 hours at $70^{\circ} \mathrm{C}$. After whlch all leaf, tip, root, and greenhouse frutt samples were ground in a Wiley Mill and stored in one-pound paper bags. One-gram samples of the oven dried tissue were ashed in a muffle furnace at $450^{\circ} \mathrm{C}$., dissolved in 15 milliliters ( $\mathrm{ml}$ ) of 40 per cent hydrochloric acld ( $\mathrm{HCl}$ ), evaporated to dryness, reheated in the muffle furnace at $450^{\circ} \mathrm{C}$. for 30 minutes to 3 hours (depending on the amount of black carbon present), dissolved in $1 \mathrm{ml}$. of 
concentrated HCI, evaporated to dryness, and diluted to volume with 0.1 normal HCI.

Frult samples collected from the field experiment were dried in $250 \mathrm{ml}$. beakers and ashed in the same manner as the other tissue samples. The entire sample was ashed and calculations were based on the oven dry welght of the samplo less beaker weight.

All samples were analyzed for potassium, calclum, and magnesium on a Beclman model DU flame spectrophotometer following the procedure outlined by Breland (12). Before the calclum and magnestum determinations were made, $10 \mathrm{ml}$. aliquots of each sample were passed through a six-inch column of anion exchange rosin (Dowex 1-8X, 50-100 mesh, medium porosity) to remove intorfering antons (33).

\section{Statlgtical Methods}

The data were analyzed by the analysis of variance methods described by Cochran and Cox (15). Probability statements of comparisons among means are based on the Duncan Multiple Range Test (19). Count data were transformed by the square root method and percentage data by the arcsin transformation beforo statistical analyses were made. All growth response data presented from the field experiment were derived from the adjusted treatment totals of the balanced-lattice design. 


\section{RESULTS OF FXPERIMENTS}

Examination of soll test data obtained from the fleld survey indicated that, In general, low yields and a high percentage of blossom-end rot were assoclated with low nutrient levels, especlally calcium and magnesium.

Data obtalned from fruit counts and soll studies from fertility experiments described by Nettles and Halsey (53) revealed that significant differences in the percentage of blossom-end rot could not be attributed to fertility treatmonts of differential levels of avallable soll nutrients. In two of the three fertility experiments significant differences in the percentage of blossom-end rot did result from replications. Further examination of the data showed that in one of the experiments the percentage of blossomend rot decreased significantly from the higher to the lower elevation of the fleld. Examination of the soll profile revealed that the soll in the upper portion of the field was slightly compact for the first 18 inches then was very loose to a depth of over 6 feet. The compactness of this upper portion of the soll decreased from the higher to the lower elevation of the fleld. From field examination of the prof1le, at the lower elevation the soll appeared to have a more desirable texture, more organic matter, and was darker in color. Examination of the data from a second experiment 
indicated that replications locatsd on a soll with a loose porous profile produced significantly more blossom-end rot than replications located on a soll with a hard-pan 12 to 24 inches below the surface. In the third experiment no significant differences resulted from replications. Examination of this soil profile revealed a uniform, relatively loose profile with no observable textural or structural differences throughout the experimental area.

The distribution of calcium, potassium, magnesium, and sodium in the varlous parts of mature watermelon plants grown under simflar environmental conditions during the spring of 1958 is shown in Table 4. By passing the sample solutions through an anion exchange resin, calcium determination values were, in general, from 20 to 35 per cent greater than those obtained from samples in which this step was ellminated. The greatest concentration of calcium, irrespective of analytical methods, and of magnestiun occurred in the older leaves with the percentages decreasing at the various sampling locations in the following order: basal leaves, mid-leaves, tips, stems, and fmits.

Statistical comparisons of the percentage of potassium, calcium, and magnesium present at different locations in the plants are shown in Table 5. The concentration of potassium was significantly less in the leaves than in other plant parts with the largest concentrations occurring in the stems and fruits. There was no significant difference between the calclum content of the stem sampling positions; however, the 


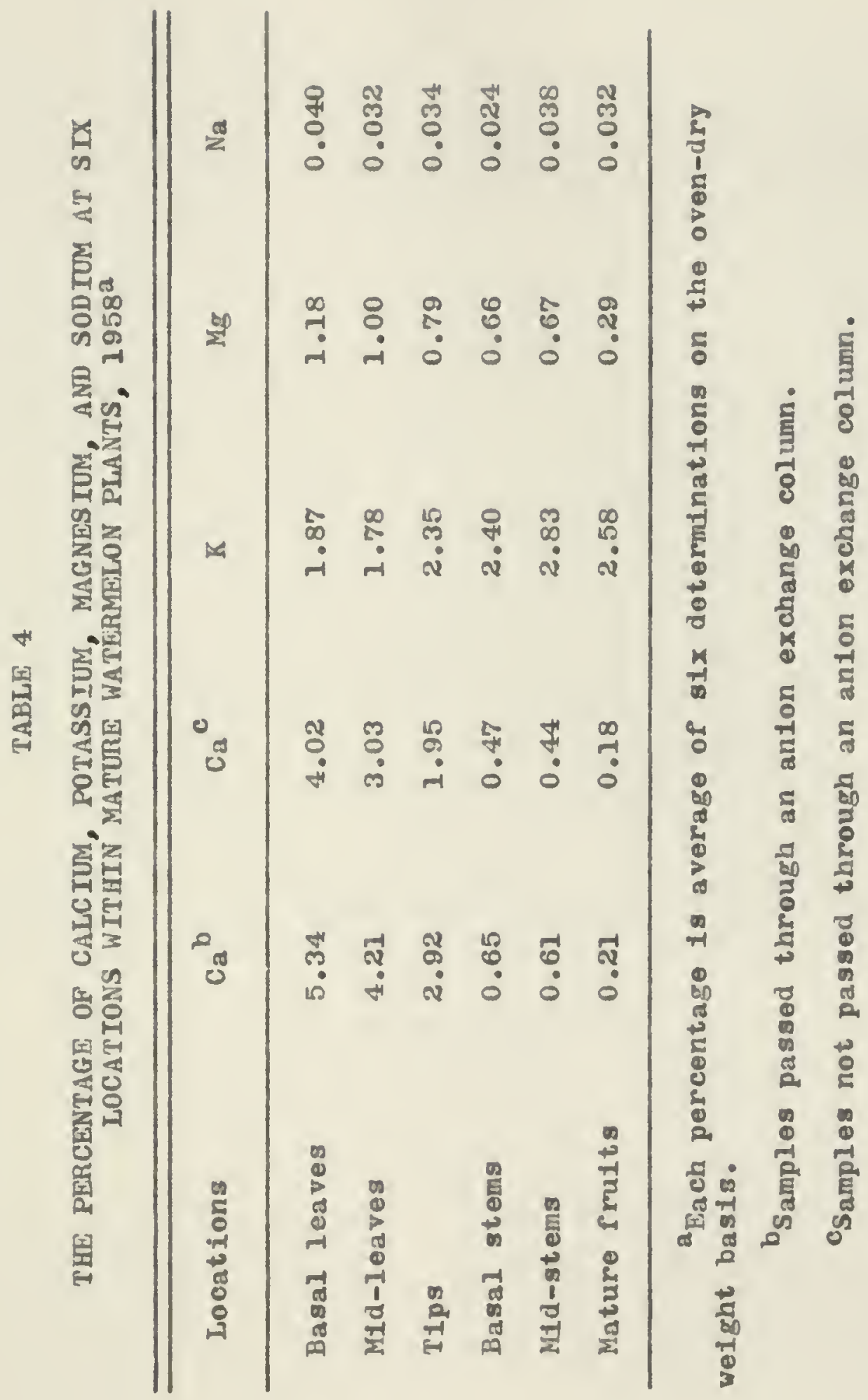


calciun percentages of all other sampling locations within the plant were significantly different from each other. This was time for the samples passed through the anion exchange columns as well as for those not passed through the columns. The magnesium content of the sampling positions in the stems did not differ significantly; however, the magnesium content of all other sampling locations within the plants differed significantly.

TABLE 5

TEST OF SIGNIFICANCE FOR THE PERCENTAGE OF POTASSIUM, CALCTUM, AND MAGNESIUM AT SIX LOCATIONS WITHIN MATURE WATERMELON PLANTSO

Fotassium percentagc

\begin{tabular}{llll}
\hline Mid- & Basal & Basal Mature Mid- \\
stem & $\begin{array}{l}\text { Mruits stom } \\
\text { leaves leaves }\end{array}$ & \\
\hline
\end{tabular}

Calcium ${ }^{b}$ and magnesium

\begin{tabular}{llll}
\hline Locations fruit Mid- & $\begin{array}{l}\text { Basal } \\
\text { stems Tips }\end{array}$ & $\begin{array}{l}\text { Mid- } \\
\text { leaves }\end{array}$ & $\begin{array}{l}\text { Basal } \\
\text { leaves }\end{array}$ \\
\hline
\end{tabular}

${ }^{a}$ Any two locations underlined by the same line were not significantly different. Any two locations not underlined by the same line were significantly different at the 5 per cent level (See Table 33 for $A .0 . V$. ).

bsignificance table for calctum analyses both with and without anion exchange resins. 
There was far greater variation in the sodium content from one plant to another than from sampling locations within any one plant; consequently, sodium analyses were eliminated in later work.

Results from exploratory follar spray experiments were inconclusive. Vine growth in the greenhouse was not affected by follar application of 0.04 molar calcium chlor1de. When each plant was allowed to set one fruit, all eight of the vines recelving no spray produced frults with obvious blossom-end rot. Two of the elght plants recelving b1-weekly sprays of 0.04 molar calcium chloride produced fruit with obvious blossom-end rot. The remaining six plants produced fruits with no external symptoms of rot; however, examination of the internal tissues revealed that three of the frufts had a semi-dehydrated, whitish, leathery type of tissue at the blossom-end. There were no significant differences in vine growth, Jield, or percentage of blossomend rot obtained from the follar spray treatments of the fleld experiment. However, it should be pointed out that the plants in this experiment were injured considerably by excessive rains.

\section{Greenhouge Phase}

\section{Growth responses}

All plants grown in solutions vold of calcium became stunted, chlorotic and all but one plant died within two 
weeks after transplanting. One plant per experimental unit was harvested from the seven remaining treatments 18 days after transplanting. The analysis of variance of the data revealed no significant differences in the dry weights of roots or tops.

Slight calcium deficiency symptoms became apparent on newly developing leaves of plants grown in $4 \mathrm{ppm}$ calcium (treatment 2) on May 8. By May 15, these deficiency symptoms were very pronounced in both the tops and the roots, and the symptoms became increasingly more severe as the season progressed. The leaves of deficient plants were dark green in color, moderately cupped under at the margins, and severely restricted especially at the apex forming a more circular type leaf (Fig. 1, No. 2).

The vine laterals of plants in treatment 2 were shorter and much more numerous than those of the other treatments. Frequently terminal growth of these short laterals would cease and more short laterals would appear which would in turn often produce other short laterals. Th1s type of growth pattern suggested a retardation or cessation of the activity of the merstimatic tissue at the apex of each vine lateral. There were no observable differences in either vine laterals or leaf formation of plants in treatments 3 through 8. However, the leaves of treatments 7 and 8 were lighter green in color and appeared to be smaller in size (Fig. 1). The root systems of plants grown in treatment 2 exhibited a growth pattern similar to the vine laterals with 
F1g. 1.--The twelfth leaf from the base of the plants in treatments $2,3,4$, 7. and 8 of the greenhouse experiment. Treatments 5 and 6 were eliminated to conserve space, because they did not appear to be different from 4. 


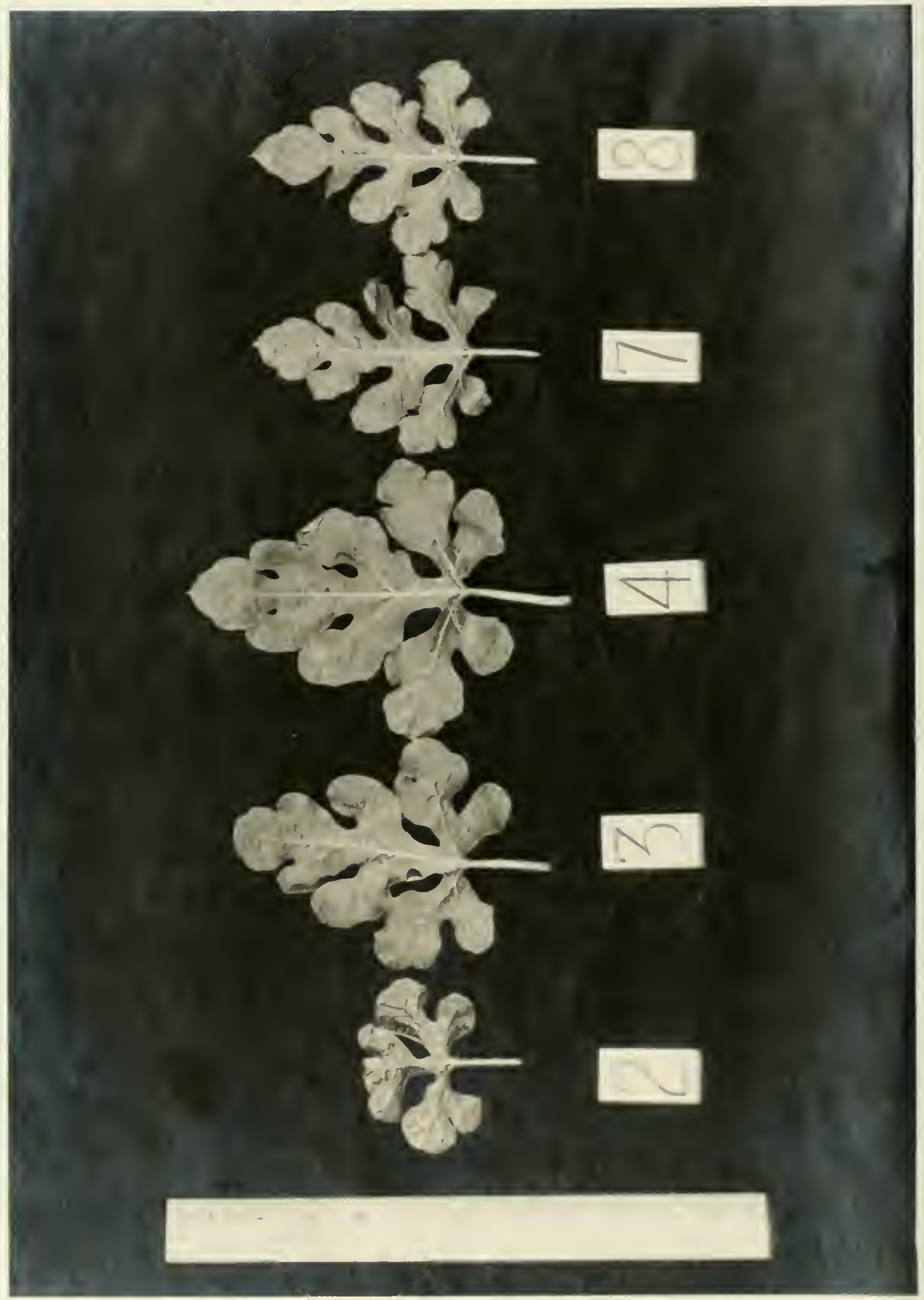


the roots being short, dense, very numorous, and often dark at the apex Indicating death (FIg. 2). Root systems of treatment 3 showed these symptoms in a very IImited degree. The root systems of treatmonts 4 through 8 appearod to be normal.

Since the calcium levels used in this experiment were $4,8,16,32,64,128$, and $256 \mathrm{ppm}$, that 18, Increased in the ratio of 2 to 1 , statistical anslyses and interpretations of the data were facllitated by considering all responses as measured against the logarlthms of the calclum concentrations. Thus, In the analysis of rariance of all data pertalning to the greenhouse expertment and to the discussion of IInear and non-IInear effects, the 1ndependent varlable 18 always the logarithm of the amount of calcium added to the nutrient solutions.

The dry welghts of vines, roots, fruits, and the total dry welght of plants are presented in Table 6 . When the vine growth was measured against the increasing calcium lovels, It was found to decrease in a highly significant Iinear trend, while the root growth responded in a signiflcant cublc fashion. There were no significant differences In the dry weight of the entire plants (vines, roots, and fruits), although it appeared to bo curvilinear. Statistical analysis was not made on the dry welght of the fruits, because they were harvested whenever external blossom-end rot became evident. 


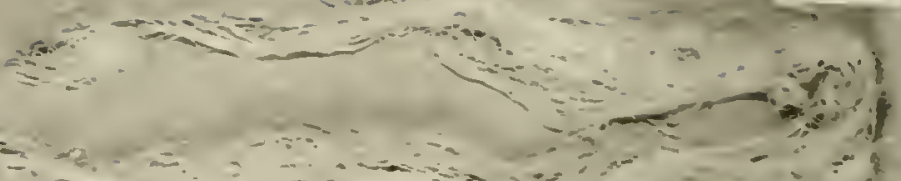

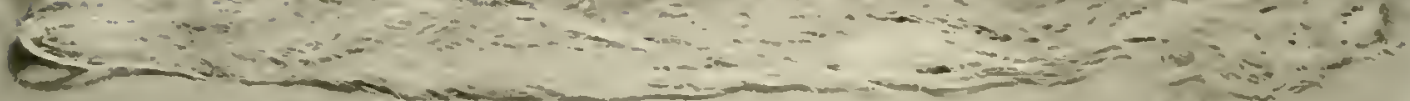

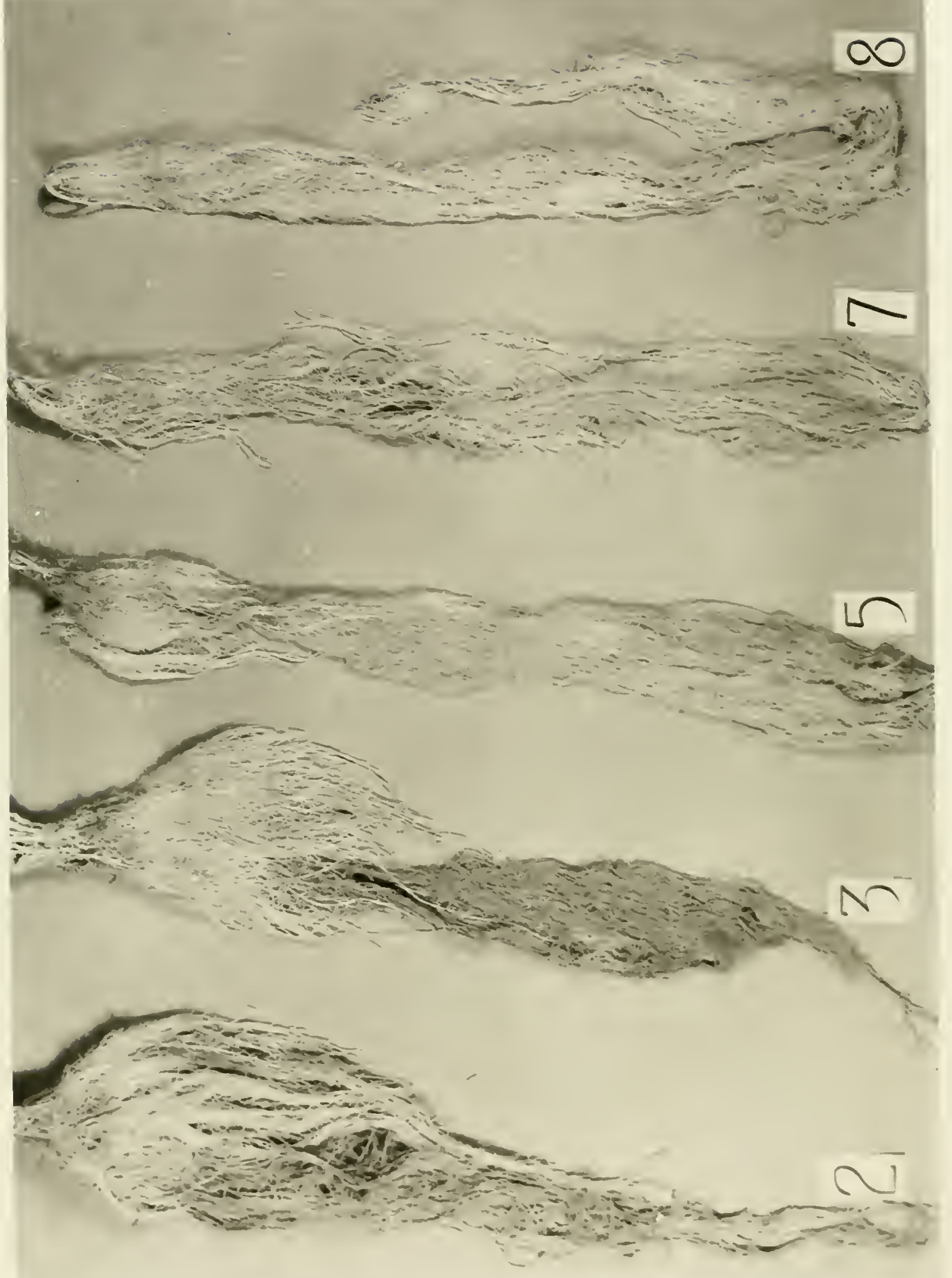


Fig. 2.--Representative root systems from treatment $82,3,5,7$, and 8 of the greenhouse experiment. Treatments 4 and 6 did not appear to bo different from 5 . 
TABLE 6

THE EFFECTS OF CALC TOM TREATMENTS ON THE DPY WEIGHT OF VINES, ROOTS, FRUITS, AND TOTAL WEIGHT IN THE GREENHOUSE' EXPER IMENT

\begin{tabular}{|c|c|c|c|c|c|}
\hline \multicolumn{2}{|c|}{ Treatment } & \multicolumn{4}{|c|}{ Dry weight in grams } \\
\hline Number & $\begin{array}{c}\text { Ca Levels } \\
\text { ppm }\end{array}$ & Vines & Roots & Fruits & Total \\
\hline $\begin{array}{l}2 \\
3 \\
4 \\
5 \\
6 \\
7 \\
8\end{array}$ & $\begin{array}{r}4 \\
8 \\
16 \\
32 \\
64 \\
128 \\
256\end{array}$ & $\begin{array}{l}79.60 \\
91.10 \\
81.60 \\
61.13 \\
60.80 \\
66.82 \\
60.05\end{array}$ & $\begin{array}{l}5.84 \\
5.80 \\
5.95 \\
3.80 \\
4.12 \\
3.72 \\
5.15\end{array}$ & $\begin{array}{r}0.00 \\
1.76 \\
33.23 \\
39.84 \\
26.86 \\
26.91 \\
32.84\end{array}$ & $\begin{array}{r}85.44 \\
98.66 \\
120.79 \\
104.76 \\
91.79 \\
97.45 \\
98.16\end{array}$ \\
\hline & $\begin{array}{l}\text { Effect: }{ }^{\text {Lf }} \\
\text { Linear } \\
\text { Quadratic } \\
\text { Cublc }\end{array}$ & $\begin{array}{l}\text { *** } \\
\text { N. S. } \\
\text { N. S. }\end{array}$ & ${ }_{*}^{*} . S$. & $\begin{array}{l}--- \\
---\end{array}$ & $\begin{array}{l}\text { N. S. } \\
\text { N. S. } \\
\text { N. S. }\end{array}$ \\
\hline
\end{tabular}

* Significant at the 0.05 level * Significant at the 0.01 level N.S. Not significant measured in grams.

$a_{\text {Each }}$ figure is the average of four replications

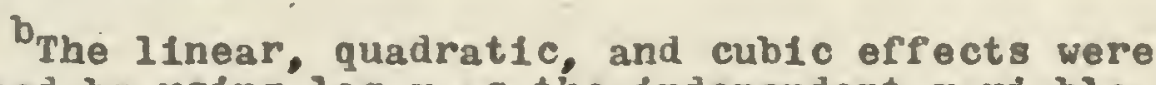
determined by using $\log x$ as the independent variable, where $x$ is the concentration of calcium in ppm in the nutrient solution (see Table 34 for A.0.V.)

Sex expression and eruit set

The number of plstillate and staminate flowers, the ratio of staminate to plstillate flowers, and the number of fruits set are given in Table 7 , and the comparisors of the square root of the means are given in Table 8. 
TABLE 7

THE EFFECTS OF CALCIUM TREATMENTS ON FLOWER PRODUCTION AND FRUIT SET IN THE GREENHOUSE EXPERIMENT

\begin{tabular}{|c|c|c|c|c|c|c|}
\hline \multicolumn{3}{|c|}{ Treatment } & \multicolumn{3}{|c|}{ Ave. No. of flowerg produced } & \multirow{2}{*}{$\begin{array}{l}\text { Total } \\
\text { number } \\
\text { of frults } \\
\text { set. }\end{array}$} \\
\hline Number & $\overline{C a}$ & $\begin{array}{l}\text { levels } \\
\text { ppm }\end{array}$ & Staminate & Pistillate & $\begin{array}{c}\text { Ratio } \\
S: P\end{array}$ & \\
\hline 2 & & 4 & 155.1 & 5.80 & 27.79 & 0 \\
\hline 3 & & 8 & 247.2 & 28.42 & 8.74 & 1 \\
\hline 4 & & 16 & 182.4 & 22.78 & 8.16 & $\overline{9}$ \\
\hline 5 & & 32 & 119.3 & 14.92 & 8.10 & 11 \\
\hline 6 & & 64 & 152.6 & 17.93 & 8.54 & 12 \\
\hline 7 & & 128 & 284.7 & 18.70 & 10.21 & 11 \\
\hline 8 & & 256 & 155.4 & 15.62 & 11.68 & 12 \\
\hline
\end{tabular}

Troatment 3 produced significantly more and treatment 5 produced significantly fewer staminate flowers than any other treatments. Treatment 2 produced the least number of pistillate flowers while treatment 3 produced the largest number. The ratio of staminate to pistillato flowers was significantly greater in treatment 2 than in any of the other treatments. No fruit was set on plants in treatment 2 (4 ppm calcium) and only one frult was set by plants in treatment 3 (16 ppm calcium). There were no significant differences in the number of frutt set from treatments 4 through 8 .

Almost all the ovaries produced by plants grown in treatment 2 turned dark brown to black in color beginning at the blossom-end, even before the flower parts opened. This also occurred rather frequently in the plants in treatment 3, but it was not observed in any of the other treatments. 
TABLE 8

TEST OF SIGNIFICANCE FOR THE EFFECTS OF CALCIUM TREATMENTS ON FLOWER PRODUCTION IN THE GREENHOUSE EXPER IMENT

Staminate flowers

Treatment

5

6

2

8

4

7

3

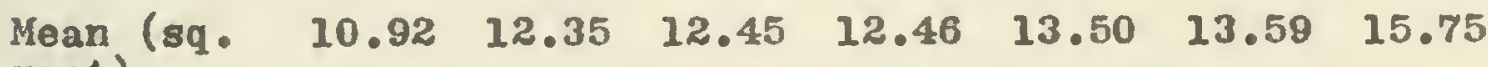
root)

Pistillate flowers

Treatment

2

5

8

6

7

4

3

$\begin{array}{llllllll}\text { Mean (sq. } & 2.41 & 3.86 & 3.95 & 4.24 & 4.32 & 4.77 & 5.33\end{array}$ root)

Ratio of staminate to plstillate flowers

Treatment

5

4

6

3

7

8

2

Mean (sq.

2.85

2.86

2.02

2.96

3.20

3.42

5.27 root)

Notes:

Any two means underlined by the same line are not significantly different. Any two not underlined by the same Iine are significantly different at the 5 per cent level (see Table 35 for the A.0.V.). 


\section{Chenteal composition}

The effects of varying levels of calclum in the substrate on the percentage of calcium, potassium, and magnesium In the leaves, tips, roots and fruits are presented in Tables 9 and 10. Statistical analyses revealed that as the logarithms of the calcium concentrationswere increased by equal amounts in substrate the calcium content of the leaves increased in quadratic fashion, the potassium content decreased in a highly signiflcant linear trend, and the magnesium content decreased in a highly significant quadratic manner.

The calcium content of the plant tips increased linearly, the magnesium content decreased in a curvilinear fashion, and the potassium content was not significantly affected by 1ncreasing increments of calclum in the nutrient solutions.

As the calcium levels were Increased, the percentage of calcium in the root tissue increased in a highly significant cubic manner, and both the potassium and magnesiva percentages decreased IInearlJ.

Analyses of the frutt from treatments 4 through 8 indicated that the potassium content of the frult was not affected by varying the calcium concentration of the substrate. However, there was a highly positive linear regression in the calcium content and a highly negative linear response in the magnesium content of the frutts when measured against increasing calcium concentrations in the nutrient solutions. 
TABLE 9

THE EFFECTS OF CALCIUM TREATMENTS ON THE PERCENTAGE OF CALCIUM, POTASSIUM, AND MAGNESIUM IN THE

LEAVES AND TIPS OF PLANTS GROWN

IN THE GREENHOUSE

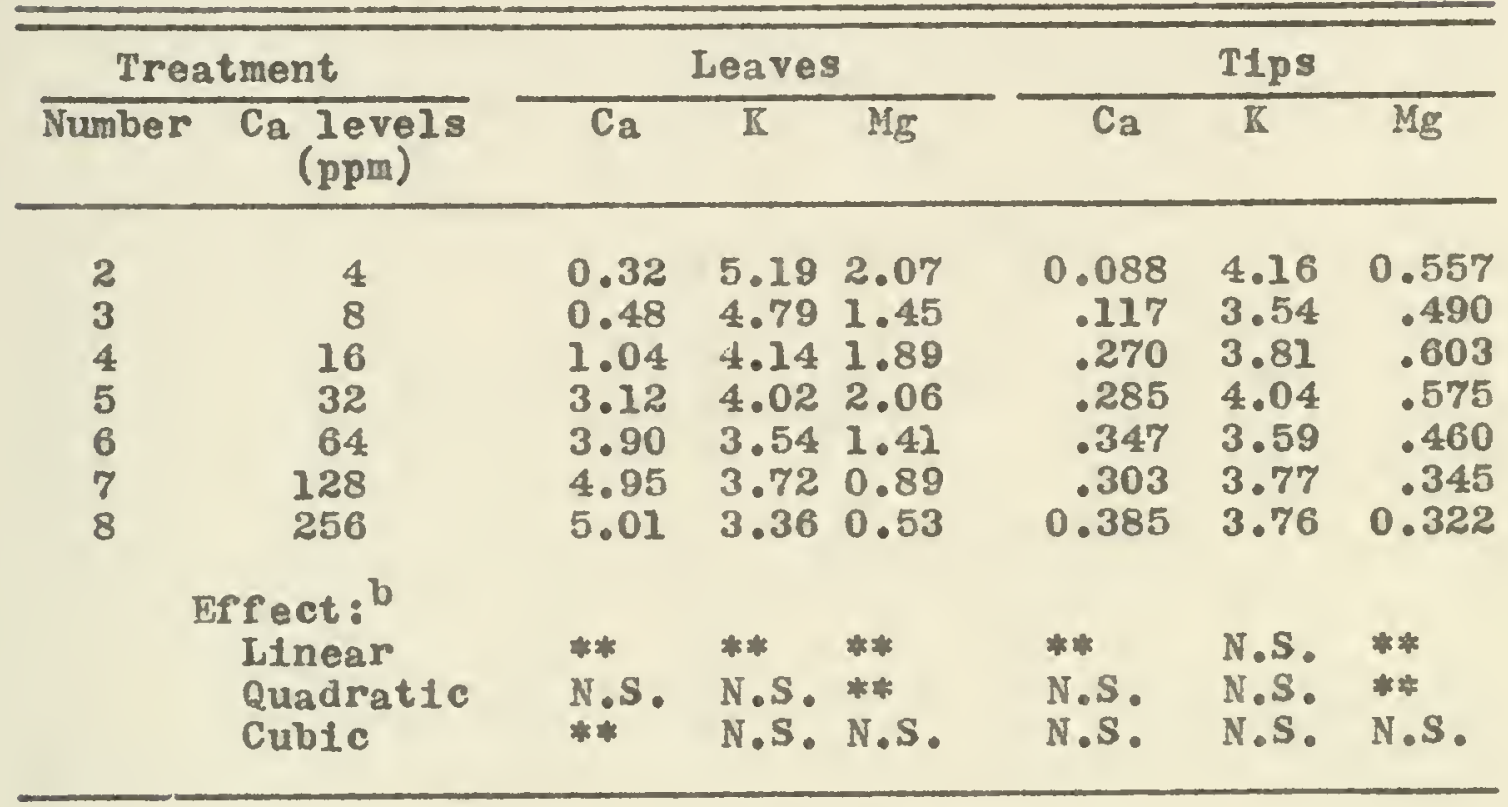

* Significant at 0.05 level

* Significant at 0.01 level

N.S. Not significant

Each percentage is the average of four replications on the dry weight basis.

${ }^{b}$ Linear, quadratic, and cublc effects were determined by using $\log x$ as the independent varlable, where $x$ equals the concentration of calcium in the nutrient solution in ppm (see Table 36 for A.0.V.). 
TABLE 10

THE FHFECTS OF CALCIUM TREATMFNTS ON THF FERCFNTAGE OF CALCTUM, FOTASSTUM, AND MAGNESIUM IN THE ROOTS AND FRUITS OF PLANTS

GROWN IN TLE GREENHOUSE ${ }^{2}$

\begin{tabular}{|c|c|c|c|c|c|c|c|c|}
\hline \multicolumn{3}{|c|}{ Treatmont } & \multicolumn{3}{|c|}{ Roots } & \multicolumn{3}{|c|}{ Fruits } \\
\hline Number & $\begin{array}{r}\mathrm{Ca} \text { lev } \\
\text { (ppn }\end{array}$ & $2^{18}$ & $\mathrm{Ca}$ & $\mathrm{K}$ & $\mathrm{Mg}$ & $\mathrm{Ca}$ & $\mathrm{K}$ & $\mathrm{Mg}$ \\
\hline $\begin{array}{l}2 \\
3 \\
4 \\
5 \\
6 \\
7 \\
8\end{array}$ & $\begin{array}{r}4 \\
8 \\
16 \\
32 \\
64 \\
128 \\
256 \\
\text { Effect } \\
\text { Line } \\
\text { Quad } \\
\text { Cuht }\end{array}$ & $\begin{array}{l}\text { a } \\
\text { ar atic } \\
\text { rate }\end{array}$ & $\begin{array}{l}0.19 \\
0.25 \\
0.38 \\
0.41 \\
0.55 \\
1.39 \\
4.85\end{array}$ & $\begin{array}{l}5.33 \\
4.92 \\
4.69 \\
3.80 \\
4.01 \\
3.79 \\
3.76\end{array}$ & $\begin{array}{r}0.525 \\
.415 \\
.420 \\
.315 \\
.312 \\
.302 \\
0.253 \\
\\
\\
\text { \#.S. } \\
\text { N.S. } \\
\text { N.S. }\end{array}$ & $\begin{array}{l}-.- \\
0.095 \\
.105 \\
.175 \\
.265 \\
0.313 \\
\\
\text { ** } \\
\text { N.S. } \\
\text { N.S. }\end{array}$ & $\begin{array}{l}-.- \\
4.87 \\
4.40 \\
4.73 \\
4.72 \\
4.53\end{array}$ & $\begin{array}{r}.- \\
0.370 \\
.320 \\
.295 \\
.273 \\
0.235\end{array}$ \\
\hline & $\begin{array}{l}* \\
* * \\
\text { N.S. }\end{array}$ & $\begin{array}{l}\text { Sign: } \\
\text { S1gn: } \\
\text { Not: }\end{array}$ & $\begin{array}{l}\text { eicant } \\
\text { etcant } \\
\text { ignifi }\end{array}$ & $\begin{array}{l}\text { at } 0 \\
\text { at } 0 \\
\text { cant }\end{array}$ & $\begin{array}{l}.05 \mathrm{lev} \\
.01 \mathrm{lev}\end{array}$ & & & \\
\hline
\end{tabular}

${ }^{2}$ Each percentage is the average of four replications on the dry weight basis.

binear, quadratic, and cubic effects were determined by using $\log x$ as the independent variable, where $x$ equals the concentration of calcium in the nutrient solution in ppm (see Tables 36 and 37 for A.0.V.). 
Eleld Phase

Soil tegts

The results of the analyses of soil samples taken within the beds are presented in Table 11. In general, the results show good correlation with the amount of hydrated lime applied. The variability within treatments may be partially attributed to at least two factors: (1) at the time of sampling small particles of hydrated lime were st111 visible in some of the soll samples and (2) replication number 3 was abnormally high in the various elements; this tended to increase the average values of all tests (seo Appendix Table 31).

\section{TABLE 11}

THE PH AND POUNDS PER ACRE OF AVA ILABLE NUTRIENTS OF SAMPLES TAKEN FROM THE WATERMELON BEDS ON APRIL 1, 1959

\begin{tabular}{|c|c|c|c|c|c|c|}
\hline Treatments $\mathrm{s}^{\mathrm{b}}$ & $\mathrm{pH}$ & $\mathrm{CaO}$ & MgO & $\mathrm{P}_{2} \mathrm{O}_{5}$ & $\mathrm{~K}_{2} \mathrm{O}$ & $\mathrm{NO}_{3}{ }^{\mathrm{c}}$ \\
\hline $\mathrm{Ca} N$ & 4.9 & 234 & 101 & 93 & 263 & VL \\
\hline $\mathrm{Ca}_{0}^{0} \mathrm{~N}_{1}^{\circ}$ & 5.0 & 147 & 85 & 80 & 227 & $\mathbf{L}$ \\
\hline $\mathrm{Ca}_{0} \mathrm{~N}_{2}^{1}$ & 4.8 & 145 & 98 & 86 & 247 & $\mathbf{L}$ \\
\hline $\mathrm{Ca}_{3} \mathrm{~N}^{2}$ & 5.3 & 373 & 73 & 77 & 226 & $\mathbf{L}$ \\
\hline $\mathrm{Ca}_{1}^{1} \mathrm{~N}_{1}^{0}$ & 5.4 & 653 & 90 & 89 & 267 & $\mathbf{L}$ \\
\hline $\mathrm{Ca}_{1}^{1} \mathrm{~N}_{2}^{1}$ & 5.4 & 628 & 87 & 90 & 226 & $\mathbf{L}$ \\
\hline $\mathrm{Ca}_{2}^{1} \mathrm{~N}_{0}^{2}$ & 5.8 & 1316 & 86 & 97 & 262 & $\mathbf{L}$ \\
\hline $\mathrm{Ca}_{2} \mathrm{~N}_{1}^{\circ}$ & 5.8 & 1511 & 65 & 99 & 231 & $M$ \\
\hline $\mathrm{Ca}_{2} \mathrm{~N}_{2}$ & 5.8 & 1967 & 116 & 91 & 228 & L \\
\hline
\end{tabular}

a Each value is the average of four replications.

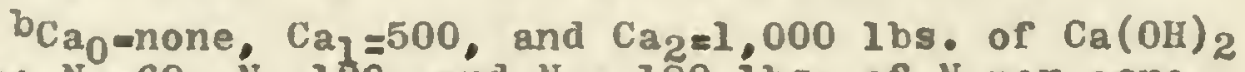
per acre; $N_{0}=60, N_{1}=120$, and $N_{2}=180 \mathrm{ibs}$. of $N$ per acre.

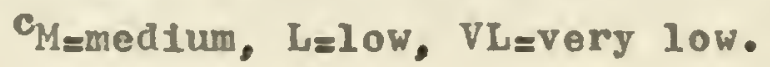


The data in Table 12 are from soil samples collected from each side of the bed within the calclum treated area. There was Iittle difference in the pII and calcium content of the various treatments. This may be explained by the fact that the beds were prepared following the lime applications which tended to concentrate the lime in the beds. The data In Table 12, excluding calclum, represent the native fertility of the plots (see Appendix Table 32).

TABLT: 12

THE PH AND POUNDS PER ACRE OF AYAILABLE NUTRIENTS OF SAMPLES TAKEN FHON EACH SIUE OF THE MELON BEDS ON APRII 1, 1959a

\begin{tabular}{lrrrrrr}
\hline Treatmeuts & $\mathrm{pH}$ & $\mathrm{CaO}$ & $\mathrm{MgO}$ & $\mathrm{P}_{2} \mathrm{O}_{5}$ & $\mathrm{~K}_{2}{ }^{0}$ & $\mathrm{NO}_{3}$ \\
\hline $\mathrm{Ca}_{0} \mathrm{~N}_{0}$ & 4.9 & 188 & 94 & 50 & 69 & $\mathrm{VL}$ \\
$\mathrm{Ca}_{0} \mathrm{~N}_{1}$ & 4.8 & 85 & 71 & 55 & 69 & $\mathrm{~L}$ \\
$\mathrm{Ca}_{0} \mathrm{~N}_{2}$ & 4.8 & 94 & 93 & 51 & 77 & $\mathrm{VL}$ \\
$\mathrm{Ca}_{1} \mathrm{~N}_{1}$ & 5.0 & 94 & 58 & 49 & 58 & $\mathrm{~L}$ \\
$\mathrm{Ca}_{1} \mathrm{~N}_{2}$ & 5.0 & 188 & 90 & 48 & 53 & $\mathrm{~L}$ \\
$\mathrm{Ca}_{2} \mathrm{~N}_{0}$ & 4.9 & 102 & 75 & 51 & 52 & $\mathrm{~L}$ \\
$\mathrm{Ca}_{2} \mathrm{~N}_{1}$ & 5.0 & 154 & 62 & 52 & 49 & $\mathrm{~L}$ \\
$\mathrm{Ca}_{2} \mathrm{~N}_{2}$ & 5.1 & 146 & 57 & 51 & 37 & $\mathrm{~L}$ \\
& 5.0 & 186 & 80 & 48 & 58 & $\mathrm{VL}$ \\
\hline
\end{tabular}

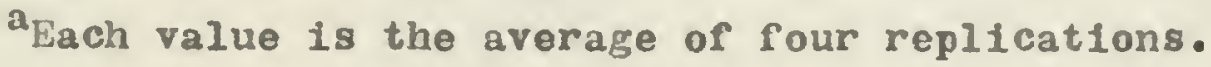

The effects of heavy raing on the removal of fertilizer from the upper elght inches of goll are shown in Table 13. It is apparent from examination of the data that all of the nitrates and approximately 50 per cent of the $\mathrm{K}_{2}{ }^{0}$ were leaohed from the upper elght inches of the soll. 
The excessive rainfall had very little effect on the levels of $\mathrm{CaO}, \mathrm{MgO}$, and $\mathrm{P}_{2} \mathrm{O}_{5}$.

\section{TABLE 13}

THE INPLUENCE OF MORE THAN EIGHT INCHES OF RAINFALL ON THE REMOVAL OF FERTILIZER NUTRIENTS IN POUNDS

PER ACRE FROM THE UPPER EIGHT INCHES

OF SOIL IN WATERMELON BEDS ${ }^{\mathrm{a}}$

\begin{tabular}{lllllll}
\hline Treatments $^{\mathrm{b}}$ & $\mathrm{pH}$ & $\mathrm{CaO}$ & $\mathrm{MgO}$ & $\mathrm{P}_{2} \mathrm{O}_{5}$ & $\mathrm{~K}_{2} \mathrm{O}$ & $\mathrm{NO}_{3}{ }^{\mathrm{C}}$ \\
\hline
\end{tabular}

Fertilizer

plus no ratn

4.8

109

86

80

426

VH

Ferlitizer

plus $8^{n} \mathrm{ral}$

5.0

80

65

90

228

I

No fertilizer

pius $8^{\prime \prime}$ rain

4.8

45

43

51

45

I

${ }^{a}$ Each figure is the average of six determinations.

bhe fertilizer'rate was $901 \mathrm{bs}$. N/acre as $\mathrm{NH}_{4} \mathrm{NO}_{3}$ $80 \mathrm{lbs}$. $\mathrm{K}_{2} \mathrm{O} / \mathrm{acre} \mathrm{as} \mathrm{KCl}$, and $80 \mathrm{lbs}$. of $\mathrm{P}_{2} \mathrm{O}_{5}$ /acre as triple superphosphate.

$$
\text { GH-very high, L-10w. }
$$

\section{Growth responses}

The dry weight of plants from eight hills per plot harvested May 1 is given in Table 14. There was a signif1cant linear increase in dry weight as the calciur levels were increased. Nitrogen did not significantly affect early vine growth or any other growth response measured in this experiment.

The number of 0 . S. Number $I$ watermelons harvested early is given in Table 15. There was a highly significant 


\section{TABLE 14}

THE EFFECTS OF CALCTUM AND NITROGEN ON EARLY VINE

GROWTH AS INDICATED BY THE DRY WEIGHT

OF EIGHT HULS PER PLOT

Pounds of hydrated Pounds of nttregen per acre Total

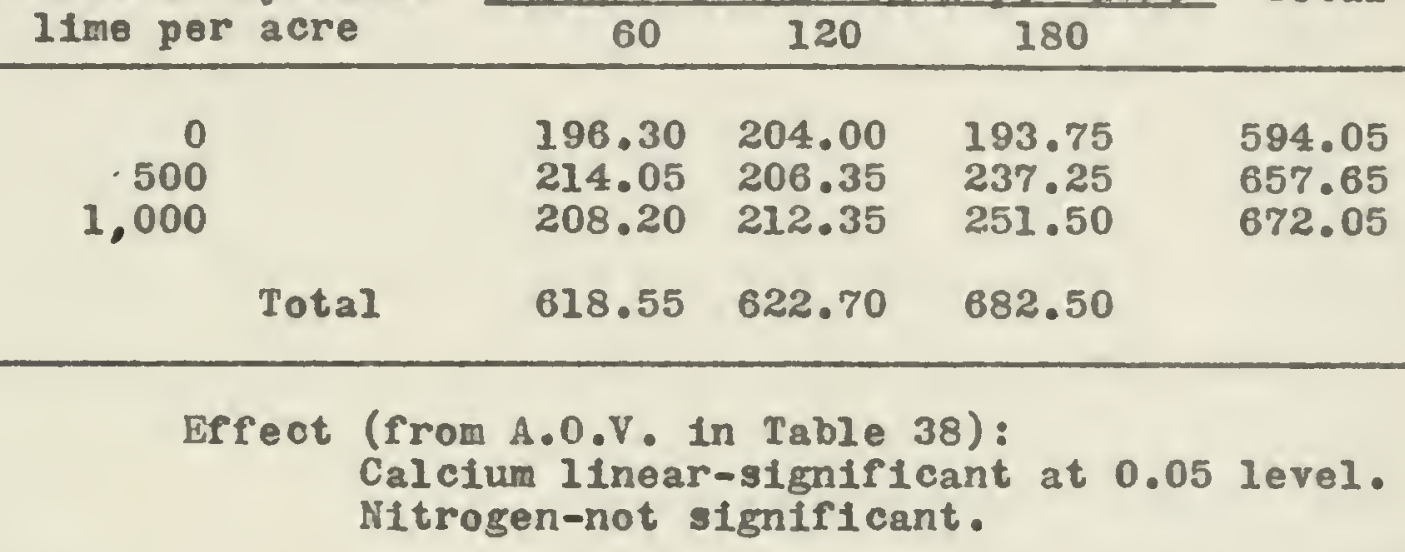

TABLE 15

THE FFFECTS OF CALCTUM AND NITROGEN ON THE NUMBER OF EARLY U. S. NUMBER 1 WATERMELONS

Pounds of hydrated Pounds of nitrogen Der acre Total

lime per acre 60 $120 \quad 180$

\begin{tabular}{rrrrrr}
\hline 0 & & 25 & 23 & 18 & 66 \\
1,000 & 30 & 32 & 31 & 93 \\
& & 37 & 28 & 44 & 109 \\
\hline
\end{tabular}

Effect (from A.0.V. in Table 38): Calcium linear-singificant at 0.01 level. Nitrogen-not significant. 
linear increase in the number of early watermelons as a result of the calcium treatments.

The total welght of U.S. Number 1 watermelons whlch was harvested early are presented in Table 16. There was a significant linear increase in the early yleld, In pounds, as a result of increasing increments of calctum.

\section{TABLE 16}

EFFECTS OF CALCIUM AND NITROGEN ON THE TOTAL WEIGHT IN POUNDS OF U. S. NUMBER 1 WATERMELONS HARVESTED EARLY Pounds of hydrated $\frac{\text { Pounds of nitrogen per acre }}{60}$ Total
l1me per acre

$\begin{array}{rrrrr}0 & 576.4 & 568.3 & 428.6 & 1573.3 \\ .500 & 765.6 & 725.8 & 779.5 & 2270.9 \\ 1.000 & 872.9 & 626.1 & 1148.5 & 2647.5\end{array}$

$\begin{array}{lll}\text { Total } & 2214.9 & 1920.2 \quad 2356.6\end{array}$

Effect (from A.0.V. In Table 38):

Calcium linear-significant at the 0.05 level. Nitrogen-not significant.

The total number of $U$. S. Number 1 watermelons harvested $1 \mathrm{~s}$ given in Table 17. The total number of watermelons produced increased in a significant fashion in response to the caloium treatments.

The total weight in pounds of $U$. S. Number $I$ watermelons, reported in Tablo 18, increased in a significant Inear manner in response to the calcium treatments. 
TABLE 17

EFFECTS OF CALCTUM AND NITROGEN ON THE TOTAL

NUMBER OF U. S. NUMBER I WATERMELONS

\begin{tabular}{rrrrrr}
$\begin{array}{c}\text { Pounds of hydrated } \\
\text { lime per acre }\end{array}$ & \multicolumn{2}{c}{ Pounds of nitrogen } & per sere & \multirow{2}{*}{ Total } \\
\cline { 3 - 4 } & 60 & 120 & 180 & \\
\hline 0 & 39 & 35 & 35 & 109 \\
1500 & 52 & 53 & 47 & 152 \\
1,000 & 58 & 45 & 59 & 162 \\
& & 149 & 133 & 141 &
\end{tabular}

Effect (from A.0.V. In Table 38):

Calclum linear-significant at the 0.05 level. Nitrogen-not significant.

TABLE 18

EFFECTS OF CALCIUM AND NITROGEN ON THE TOTAL WEIGHT

IN POUNDS OF U. S. NUMBER 1 WATERMELONS

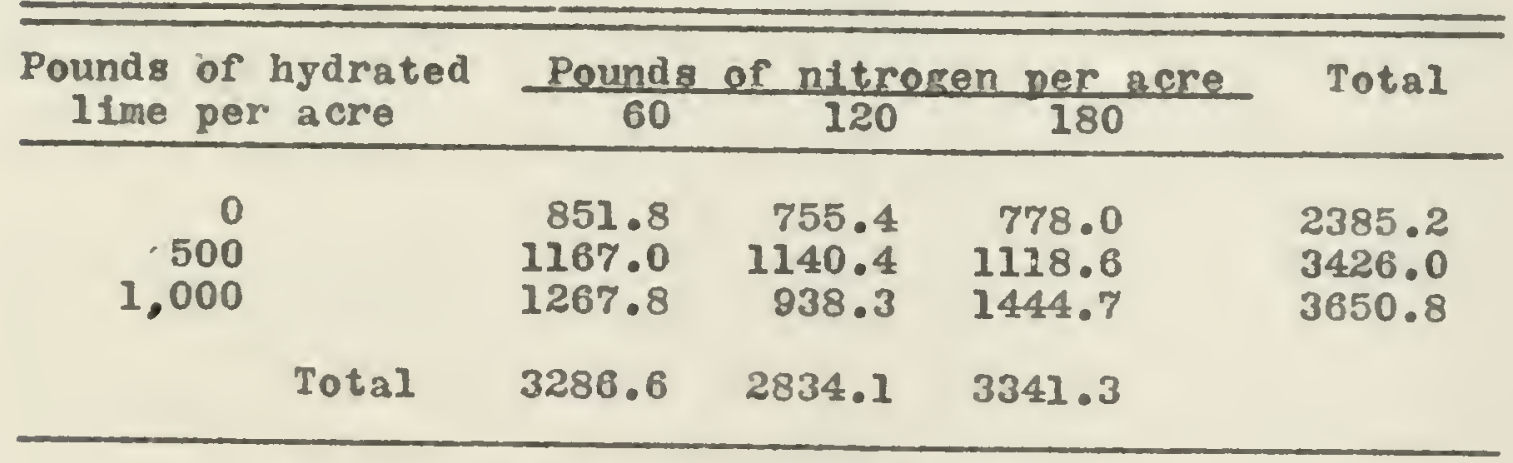

Effect (from A.0.V. In Table 38):

Calcium linear-significant at the 0.05 level. Nitrogen-not significant. 
The average of soluble solids as per cent sucrose of all marketable fruit from each plot is reported in Table 19. The average percentage of soluble solids was not significantly affected by elther the nitrogen or the calcium treatments.

\section{TABLE 19}

THE FFFECTS OF CALCIUM AND NITROGEN ON THE AVERAGE SOLUBLE SOLIDS AS PER CENT SUCROSE FROM ALL MARKETABLE MELONS PER PLOT

Pounds of hydrated lime per acre $\overline{1}$ $\frac{\text { Pounds of nitrogen per acre }}{60} \frac{120}{180}$ 9.97

$9.68 \quad 10.03$
9.78

9.48

9.74

Mean

0
500
, 000
Mean
Effect (from A.0.V. In Table 39): Not significant.

Mean 9.95
9.95
9.55 9.65 10.24 10.12

9.46

9.72

The average thickness of the rinds measured at the top and bottom center of all marketable fruits is shown in Table 20. The average thickness of the rind at these 10cations was not affected significantly by any treatment combination.

The average thickness of the rind at the blossomend of all marketable fruits per plot 18 given in Table 21. A Inear reduction in the thickness of the rind at the blossom-end was associated with increasing inorements of calcium. 
TABLE 20

THE EFFECTS OF CALCIUM AND NITROGEN ON THE AVERAGE THICKNESS OF THE RIND IN CENTIMETERS AT THE TOP CENTER AND BOTTOM CENTER OF ALL MARKETABLE FROITS

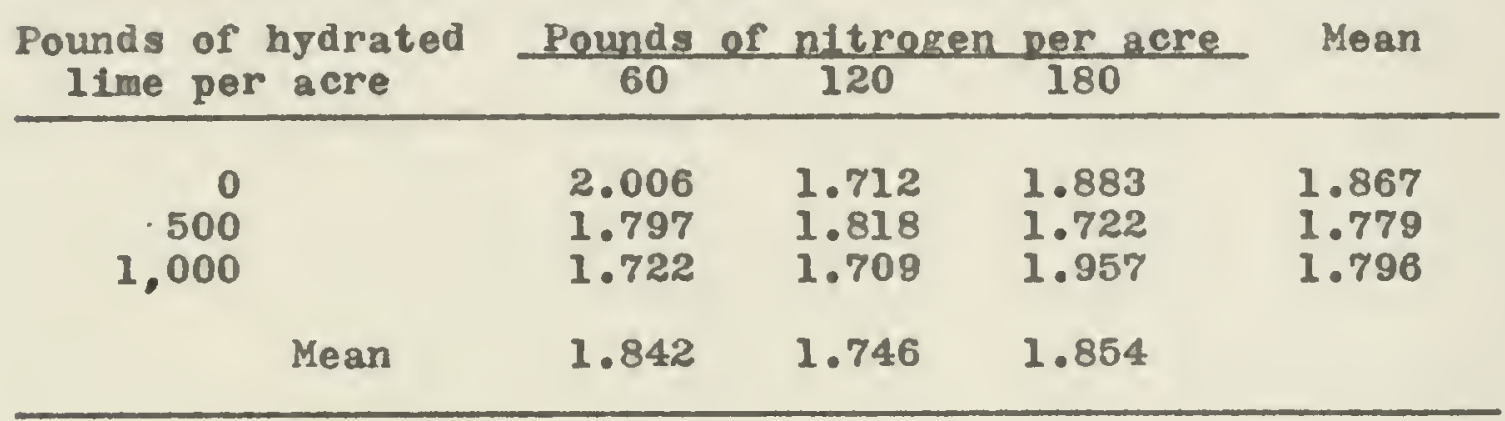

Effoct (from A.0.V. In Table 39): Not significant.

TABLE 21

THE EFFECTS OF CALCIOM AND NITROGEN ON THE AVERAGE THICKNESS OF THE RIND IN CENT IMFTERS AT THE BLOSSOM-END OF ALL MARKETABLE FRUTTS

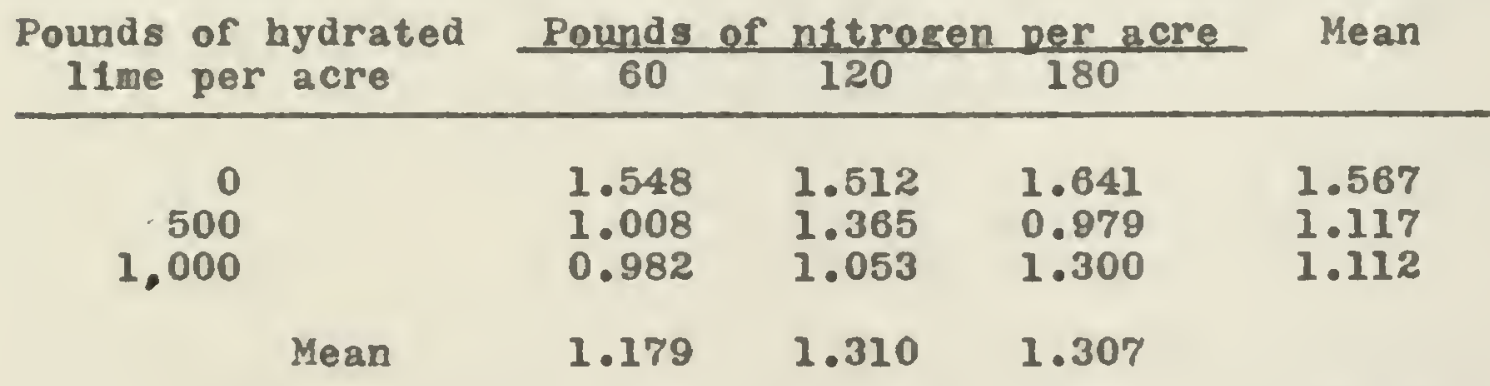

Effect (from A.0.V. in Table 39):

Calcium Iinear-significant at the 0.05 level. Nitrogen-not significant. 
The average percentage of blossom-end rot of the watermelon frults associated with each treatment combination is given in Table 22. The analysis of variance of this data revealed no significant difference among treatments.

\section{TABLE 22}

THE EFFECTS OF CALCIOM AND NITROGEN ON THE PERCENIAGE OF BLOSSOM-FND ROT

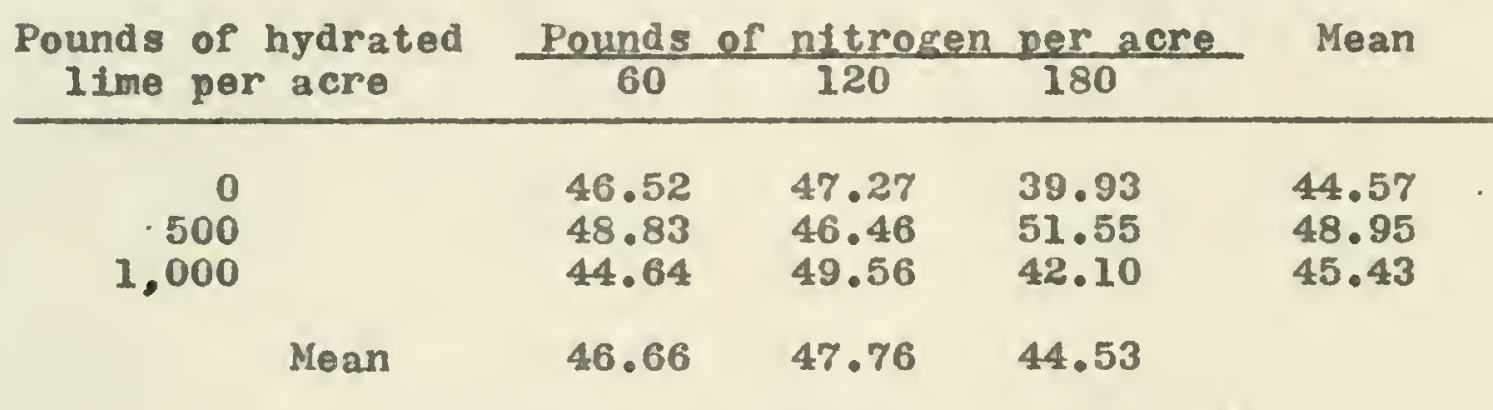

Effect (from A.0.V. In Table 39): Not significant.

All fruits were examined for hollow-heart, whiteheart, and other abnormalities; however, these disorders were very IImited in occurrence and of no importance in this experiment.

Fruit set

The total number of fruits set per treatment is shown in Table 23. There was a significant positive quadratic response to the increasing calcium levels. Nitrogen treatments had no significant effect on the total number of fruits set. 
THE EFFECTS OF CALCIUM AND NITROGEN ON THE TOTAL NUMBER OF FRUITS SET

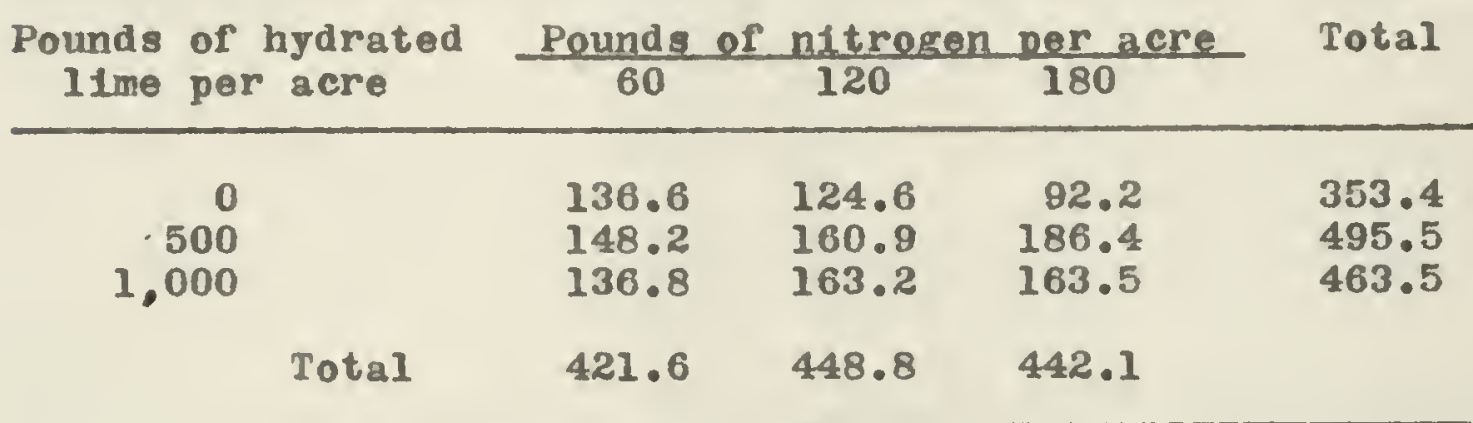

Effect (from A.0.V. In Table 39):

Calcium Iinear-significant at 0.05 level. Calcium quadratic-significant at 0.05 level. Nitrogen-not significant.

\section{Chemtcal composition}

The percentage of calcium, potassium, and magnesium in the tips of young watemelon plants on May 1 is presented in Table 24. There was a highly slgnificant linear increase in the calcium content of the tips as the calcium supply was increased in the soil. The calcium content of the tips was not affected by the nitrogen treatments. Nelther the potassium nor magnegium content of the young tips was influenced by the application of nitrogen or calcium to the so11.

The cation composition of the leaves from young watermelon plants is shown in Table 25. The calcium content of the leaves gave a curvilinear response to calcium treatments, increasing with increasing amounts of 1 ime per acre. In response to nitrogen treatments, however, the 


\section{TABLE 24}

THE EMFECTS OF CALCIUM AND NITROGEN ON THE PERCENTAGE OF CALCIUM, POTASSIUM, AND MAGNESIUM IN THE TIPS OF YOUNG WATERMELON PLANTS

\begin{tabular}{cccc} 
Pounds of hydrated & \multicolumn{2}{c}{ Pounds of nitrogen per acre } & Mean \\
\cline { 3 - 3 } lime per acre & 60 & 120 & 180
\end{tabular}

Calcium Content

$\begin{array}{rllll}0 & 0.545 & 0.385 & 0.340 & 0.423 \\ 500 & 0.555 & 0.630 & 0.713 & 0.633 \\ 1.000 & 0.713 & 0.937 & 0.722 & 0.791\end{array}$

Mean

$0.604 \quad 0.651$

0.594

Potasstum Content

$\begin{array}{rllll}0 & 5.61 & 4.69 & 5.11 & 5.14 \\ 500 & 5.19 & 5.02 & 5.55 & 5.25 \\ 1,000 & 5.26 & 5.00 & 5.51 & 5.26\end{array}$

Mean $\quad 5.35 \quad 4.90 \quad 5.39$

Magnesium Content

$\begin{array}{rllll}0 & 0.340 & 0.285 & 0.300 & 0.308 \\ .500 & 0.285 & 0.323 & 0.298 & 0.302 \\ 1,000 & 0.292 & 0.308 & 0.288 & 0.296\end{array}$

$\begin{array}{llll}\text { Mean } & 0.306 & 0.305 & 0.295\end{array}$

Effect (from A.O.V. In Table 40):

Calcium content-calcium linear $\left(\mathrm{Ca}_{L}\right)$ significant at 0.01 level.

Potassium content-not significant.

Magnesium content-not significant. 
TABLE 25

TUE EFFECTS OF CALCIUM AND NTTROGEN ON THE PERCENTAGE OF CALCTOM, POTASSIUM, AND MAGNESTUM IN THE

LEAVES OF YOUNG WATERMELON PLANTS

Pounds of hydrated IIme per acre

Pou

$\underline{11+0}$

\section{Calctum Content}

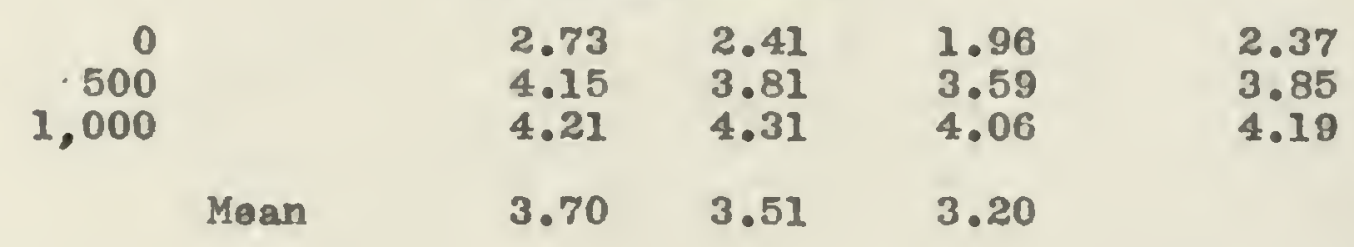

Potassium Content

\begin{tabular}{|c|c|}
\hline $\begin{array}{r}0 \\
.500 \\
1,000\end{array}$ & $\begin{array}{l}5.82 \\
5.33 \\
5.37\end{array}$ \\
\hline & \\
\hline
\end{tabular}

Masnesium Content

\begin{tabular}{|c|}
\hline $\begin{array}{r}0 \\
.500 \\
1,000\end{array}$ \\
\hline \\
\hline
\end{tabular}

Effect (from A.O.V. In Table 40):

Calcium content-Ca , cal cium quadratic ( $\left.\mathrm{Ca}_{\mathrm{g}}\right)$, and nitrogen linear $\left(\mathrm{N}_{\mathrm{L}}\right)$ significant

Potassium content-CaL significant at 0.05 level.

Magnesium content-Ca significant at 0.01 level; $\mathrm{Ca}_{L} \times \mathrm{N}_{L}$ significant at 0.05 level. 
calclum content showed a highly slgniflcant linear regresslon, decreasing as the nitrogen levels were increased. Potassium content also showed a significant linear regression, docreasing as the calctum levels were increased in the soll. The magnesium content of the leaves similarly decreased in a highly significant linear trend as a result of increasing the calcium levols. However, a significant Iinear interaction was discovered between the Iinear responses of calctum and nttrogen, $\mathrm{Ca}_{\mathrm{L}} \times \mathrm{N}_{\mathrm{L}}$, on the magnesium content of the leaves of young plants (Fig. 3). The effect of increasing nitrogen on the linear response to the calcium treatments was to change the regression from negative to slightly positive as the nitrogen levels increased from 60 to 180 pounds per acre.

The effect of the calcium and nitrogen treatments on the cation composition of the tips from the mature watermelon plants is presented in Table 26. The calcium treatments had no significant effect on the cation composition of the mature tips. The potassium and magnesium content of the tips, however, responded in a significant negative linear fashion to the increasing nitrogen lovels.

The cation composition of the leares from mature plants is glven in Table 27. Nitrogen treatments had no significant effect on the percentage of potasium, calcium, or magnesium in the mature leaves. The calcium content of the leaves was increased in a highly significant quadratic 


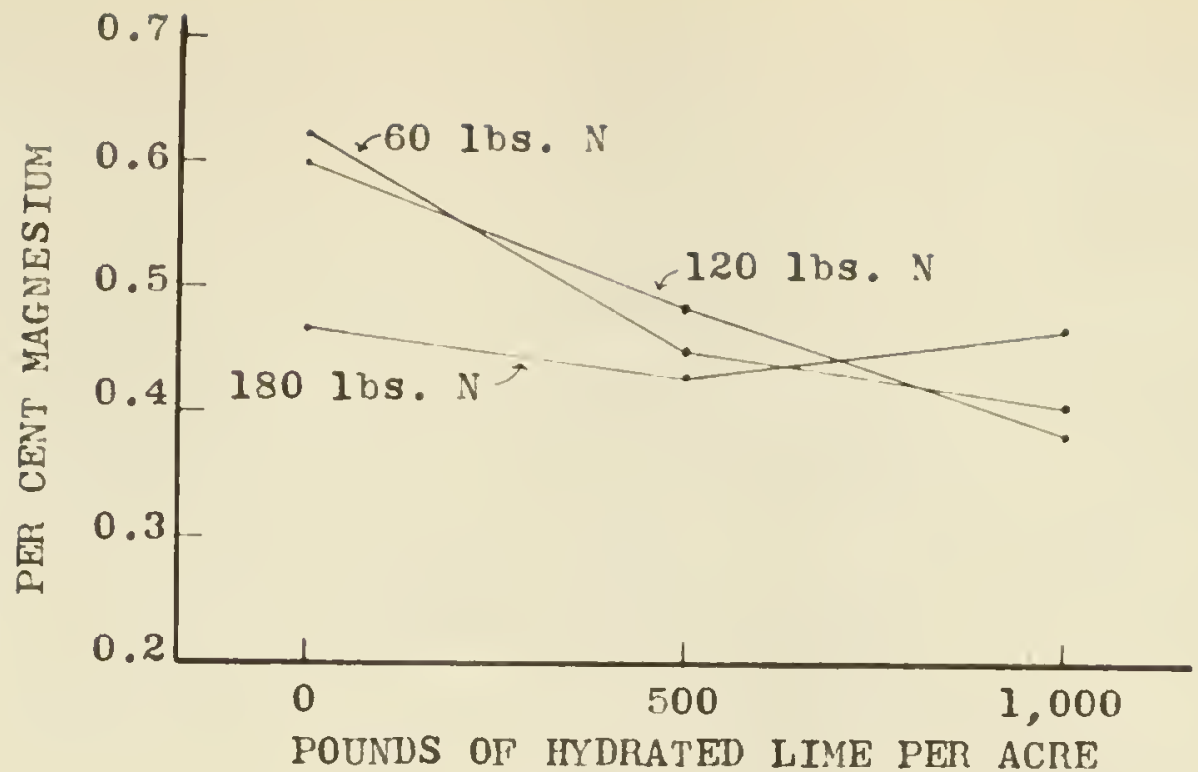

Fig. 3.--ihe interaction of calcium and nitrogen $\left(\mathrm{Ca}_{\mathrm{L}} \mathrm{X} \mathrm{N}_{\mathrm{L}}\right.$ ) on the magneslum content of the leaves of young watermelon plants

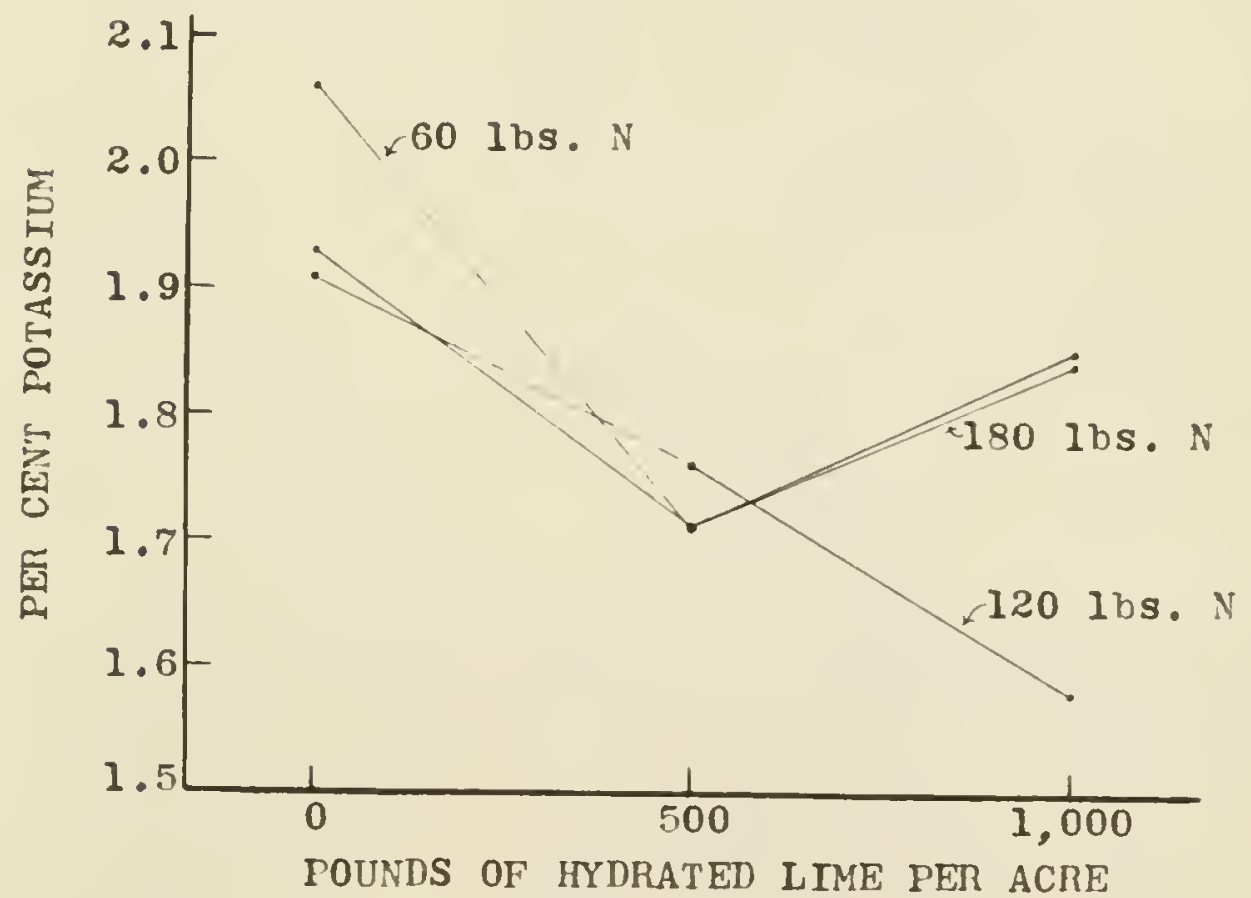

Fig. 4.--The interaction of calcium and nitrogen $\left(\mathrm{Ca}_{Q} X \mathrm{~N}_{Q}\right)$ on the potassium content of U. S. Number 1 watermelons. 
THE EFFECTS OF CALCIUM AND NITROGEN ON THE PERCENTAGE OF CALCTUM, POTASSIUM, AND MAGNESIUM IN THE TIPS OF MATURE WATERMELON PLANTS

Pounds of hydrated lime per acre

Pounds of nitrogen per acce

Mean

\begin{tabular}{|c|c|c|c|c|c|}
\hline \multirow{3}{*}{$\begin{array}{r}0 \\
500 \\
1,000\end{array}$} & & \multicolumn{3}{|c|}{ Calclum Content } & \multirow{3}{*}{$\begin{array}{l}0.280 \\
0.332 \\
0.330\end{array}$} \\
\hline & & $\begin{array}{l}0.285 \\
0.370 \\
0.365\end{array}$ & $\begin{array}{l}0.230 \\
0.300 \\
0.325\end{array}$ & $\begin{array}{l}0.325 \\
0.325 \\
0.300\end{array}$ & \\
\hline & Mean & 0.340 & 0.285 & 0.317 & \\
\hline
\end{tabular}

\section{Potassium Content}

\begin{tabular}{|c|c|}
\hline $\begin{array}{r}0 \\
.500 \\
1,000\end{array}$ & $\begin{array}{l}3.84 \\
3.35 \\
3.26\end{array}$ \\
\hline & 3.48 \\
\hline
\end{tabular}

\section{Masnestum Content}

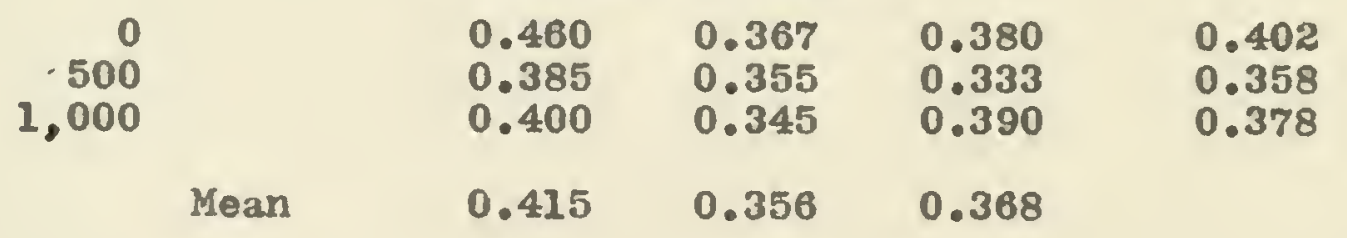

Erfect (from A.0.V. in Trble 41):

Calcium content-not significant.

Potassium content-N $N_{L}$ signiflcant at 0.05 level.

Magnesium content-N $N_{L}$ significant at 0.05 level. 


\section{TABLE 27}

THE EFFECTS OF CALCIUM AND NITROGEN ON THE PERCENTAGE OF CALCIUM, POTASSIUM, AND MAGNESIUM IN THE LEAVES OF MATURE WATERMELON PLANTS

Pounds of hydrated IIme per acre $\frac{\text { Pounds of nitrogen per acre }}{60} \frac{120}{180}$

Mean

Calcium Content

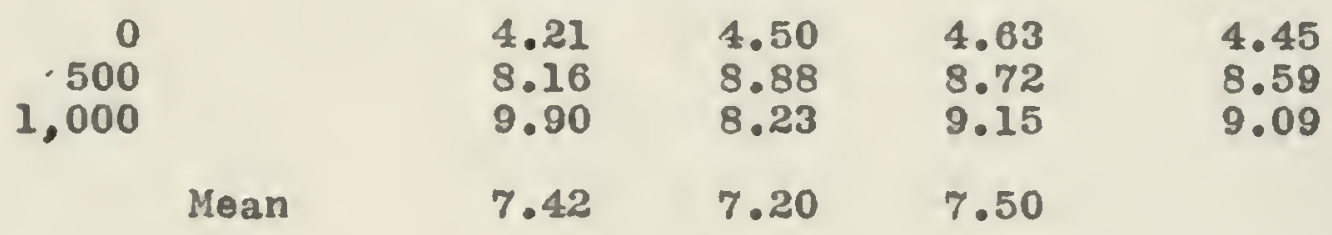

Potasstum Content

\begin{tabular}{|c|c|c|c|}
\hline $\begin{array}{r}0 \\
r 500 \\
1,000\end{array}$ & $\begin{array}{l}3.21 \\
1.96 \\
1.96\end{array}$ & $\begin{array}{l}2.79 \\
2.19 \\
1.79\end{array}$ & $\begin{array}{l}2.81 \\
1.83 \\
2.08\end{array}$ \\
\hline Mean & 2.38 & 2.26 & 2.24 \\
\hline
\end{tabular}

Marnestum Content

$\begin{array}{rllll}0 & 1.070 & 1.111 & 0.947 & 1.040 \\ 500 & 1.020 & 1.050 & 0.902 & 0.991 \\ 1,000 & 0.942 & 0.850 & 0.968 & 0.920\end{array}$

Kean

$\begin{array}{lll}1.010 & 1.003 \quad 0.939\end{array}$

Effect (from A.0.V. In Table 4I):

Calcium content-Ca, $\mathrm{Ca}_{Q}$ significant at 0.01 level.

Potassium content-CaL, CaQ significant at 0.01 level.

Magnesium content-not significant. 
Pashion and the potassium content was decreased in a highly significant quadratic manner as the calcium levels were Increased in the soll.

The results of the analyses of the mature marketable fruit for calcium, potassium, and magnesiun are shown in Table 28. The calctum content increased in a bighly significant manner as a result of the calctum applications, and it decreased in a highly significant quadratic fashion as a result of the nitrogen treatments. The potassium content showed significant quadratic regressions as a result of both calclum and nitrogen treatments. However, these relationships are complicated by a quadratic interaction $\left(\mathrm{Ca}_{Q} \times \mathrm{N}_{Q}\right.$ ) shown in Fig. 4. The quadratic regression on calctum changed drastically from "concave upward" for 60 and 180 pounds of nitrogen to "concave downward" for the 120 pounds of nitrogen applied per acre. The magnesium content responded to nitrogen only, and this was a quadratic relationship.

The composition of the frults exhibiting blossomend rot 18 shown in Table 29. The calcium content of the fruit showed a strong linear regression, increasing in response to increasing increments of applied calcium. The potassium content responded negatively to the calcium treatments and positively to the nitrogen treatments. However, a significant interaction $\left(\mathrm{Ca}_{L} \times \mathrm{N}_{Q}\right)$ is quite evident in Fig. 5. Here the shape of the ilnear regression of 
TABLE 28

THE EFFECTS OF CALCIUN AND NITROGEN ON THE PERCENTAGE OF CALCTUM, POTASSTUM, AND MAGNESIUM IN U.S. NUMBER I WATERMELON FRUITS

Pounds of hydrated Pounds of nitrogen per acre Mean $\begin{array}{llll}\text { lime per acre } & 60 & 120 & 180\end{array}$

\section{Calctum Content}

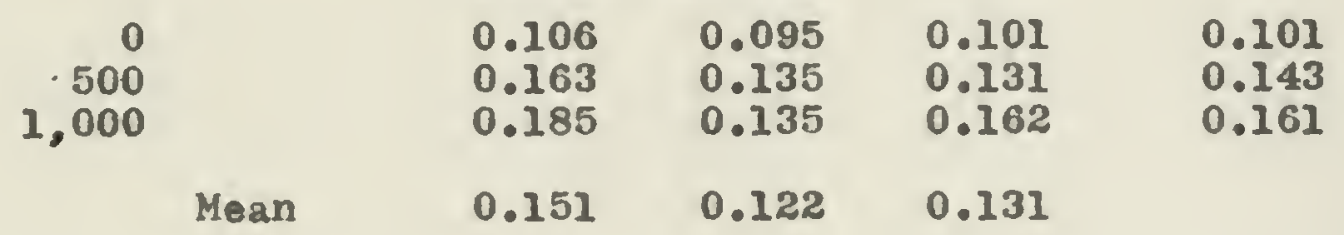

Petassium Content

\begin{tabular}{|c|}
\hline $\begin{array}{r}0 \\
.500 \\
1,000\end{array}$ \\
\hline \\
\hline
\end{tabular}

Magnesfum Content

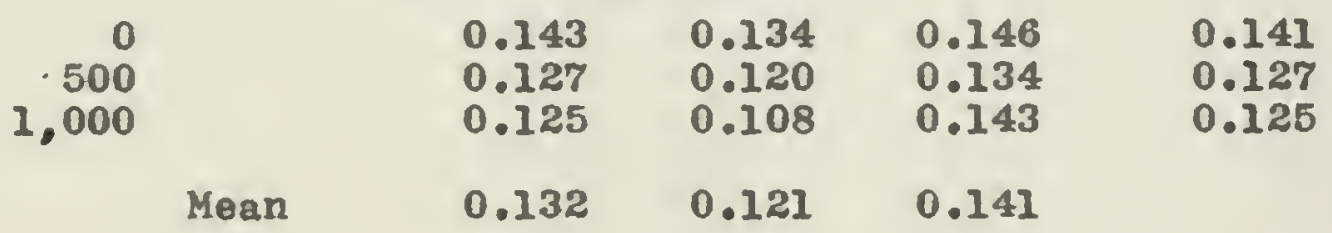

Effect (from A.0.V. In Table 42):

Calclum content-CaL significant at 0.01 level; N, $N$ significant at 0.05 level. Potassium content-CaL. CaQ singificant at 0.01 level; $\mathrm{N}_{Q}, \mathrm{Ca}_{Q} \mathrm{X} \mathrm{N}_{Q}$ significant at 0.05 level. Magnesium content-N $N_{Q}$ significant at 0.05 level. 
THE ERFECTS OF CALCIUM AND NITROGEN ON THE PERCENTAGE OF CALCIUM, POTASSTOM, AND MAGNESTUM IN WATERMELON FRUITS EXRIBITING BLOSSOM-END ROT

\begin{tabular}{cccc} 
Pounds of hydrated & \multicolumn{2}{c}{ Pounde of nitrosen ner acre } & Mean \\
\cline { 2 - 4 } lime per acre & 60 & 120 & 180 \\
\hline
\end{tabular}

Calcium Content

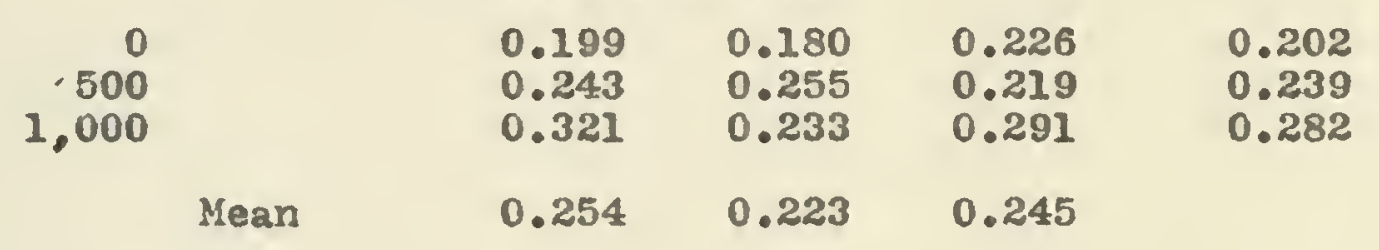

\section{Potassium Content}

\begin{tabular}{|c|}
\hline 0 \\
\hline 500 \\
\hline 1,000 \\
\hline \\
\hline
\end{tabular}

Magnesium Content

\begin{tabular}{|c|}
\hline $\begin{array}{r}0 \\
.500 \\
1,000\end{array}$ \\
\hline \\
\hline
\end{tabular}

Effect (from A.0.V. In Table 42):

Calcium content-Cay significant at 0.01 level. Potassium content-Car significant at 0.01 level; $N_{L}, \mathrm{Ca}_{L} \times \mathrm{N}_{Q}$ significant at 0.05 level. Magnesium content-Ca significant at 0.01
level; Ca $X \mathrm{~N}_{L}$ slgnificant at 0.05 ievel. 


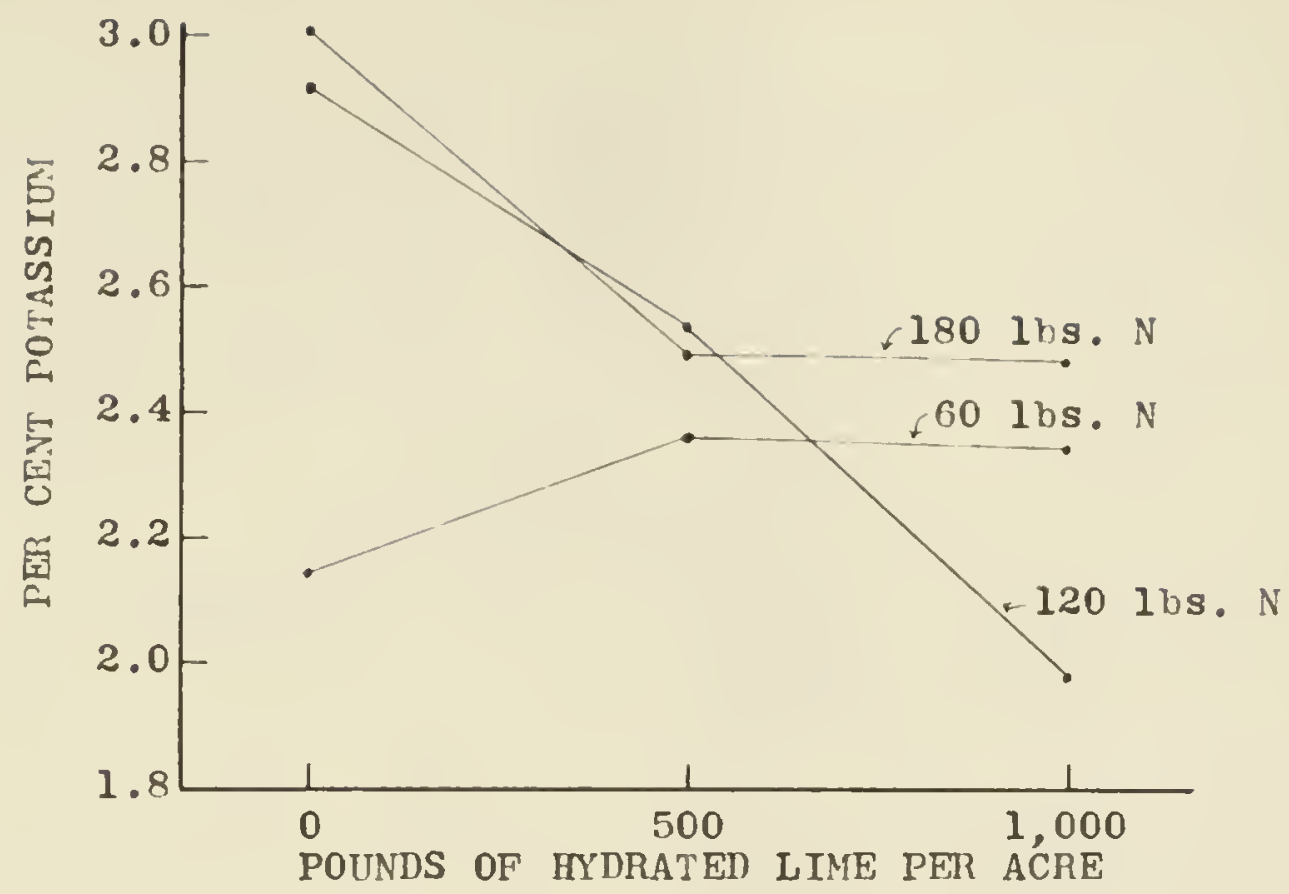

Fig. 5.--The interaction of calcium and nitrogen $\left(\mathrm{C}_{L} X \mathrm{~N}_{Q}\right.$ ) on the potassium content of watermelon fruits exhibiting blossom-end rot.

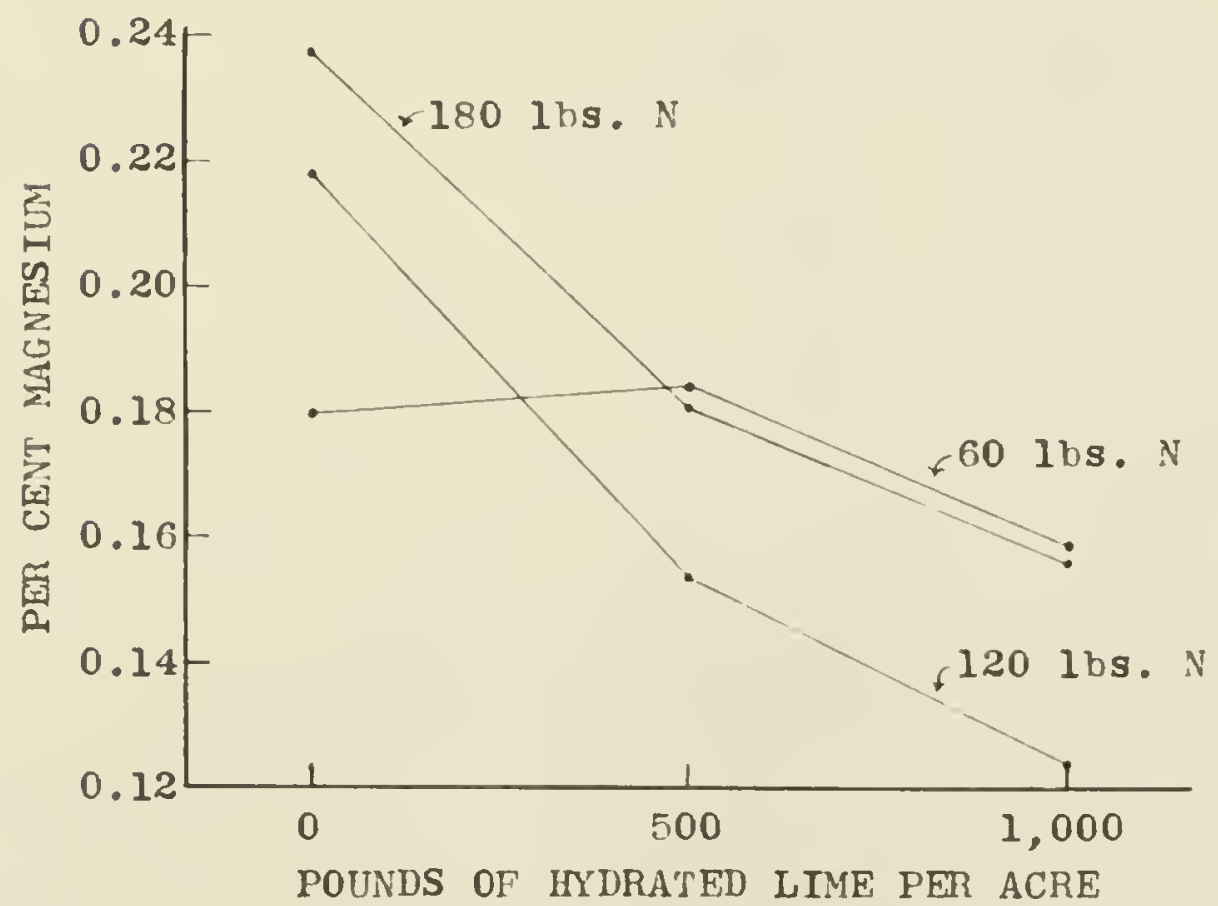

Fig. 6.--The interaction of calcium and nitrogen $\left(\mathrm{C}_{\mathrm{L}} \mathrm{X} \mathrm{N}_{\mathrm{L}}\right.$ ) on the magnesium content of watermelon fruits exhibiting blossom-end rot. 
potassium on calcium changed rarkedly from positive to negative in a curvilinear fashion for different levels of nitrogen. The highly gignificant linear reduction in the magnesium content in response to calcium treatments appeared to be influenced by the nitrogen levels. It is evident by the Inear Interaction $\left(\mathrm{Ca}_{L} \times \mathrm{N}_{L}\right)$ of the magnestum content on calcium shown in Fig. 6. The graph clearly shows how the negative slope of the regression becomes steeper as the nitrogen is increased above 60 pounds of nitrogen per acre. 


\section{DISCUSSION}

\section{Growth Responses}

In the greenhouse experiments with watermelons, any level of calclum in the nutriont solution from 4 to $256 \mathrm{ppm}$ appeared to produce normal growth of plants the first two weeks after transplanting. After this, plants grown in solutions containing $4 \mathrm{ppm}$ of calclum began to develop doficlency symptoms in the leaves, vinos, and roots, and these symptoms grew increasingly more pronounced as the season progressed. Within three days all watermelon plants placed in solutions containing no calclum began developing deficlency symptoms which resulted in death of the plants in approximately two woeks. These vistble symptoms appeared to be characteristio of a severe calcium deflelency rather than toxiclty of any other element or elements. No deficlency symptoms were apparent in the tops of plants grown in $8 \mathrm{ppm}$ calctum; however, the roots did show obvious deficiency symptoms at the $8 \mathrm{ppm}$ level but not at $16 \mathrm{ppm}$ of calclum. Research reported by Blajulph et al. (7) Indicated that Red Kidney bean plants survired in nutrient solutions containing as low as 0.05 millimoles (2 ppm) of calcium. Below this level, the beans developed a severe deficlency or chlorosis which resulted in death. 
The negative linear relationships existing between the dry welght of vines or the dry welght of the roots and the calclum concentrations, when expressed logarithmically, may be explained by the fruit jields (F1g. 7). In solutions contalning 16 through $256 \mathrm{ppm}$ of calcium a considerable part of the total plant welght was represented by the dry wolght of the fruits. This is apparent by observation of the non-significant quadratic trend in total weight. The curvilinear response of root growth is unquestionably mainly a response to treatments; however, it may be partially attributed to the amount of the base portion of the main stem harvested with the root systems. Therefore, the negative linear pattern appears to describe the data adequately (Fig. 7)

The positive linear response of early vine growth to calcium treatments in the fleld ( $T a b l e$ 14) is in general agreement with data obtained from a preliminary sand-pot experiment. Pots of Loon fine sand receiving 600 pounds of hydrated lime per acro produced significantly more vine growth than pots recelving no lime, but vine growth was not significantly different in pots recelving 600; 1,200; 1,800; or 2,400 pounds of hydrated lime per acre. Field application of nitrogen did not influence the early vine growth signiflcantly. Thls may be explained on elther of the following assumptions: (1) the excessive rains following application partially eliminated the nitrogen variable or (2) sufficient 
71

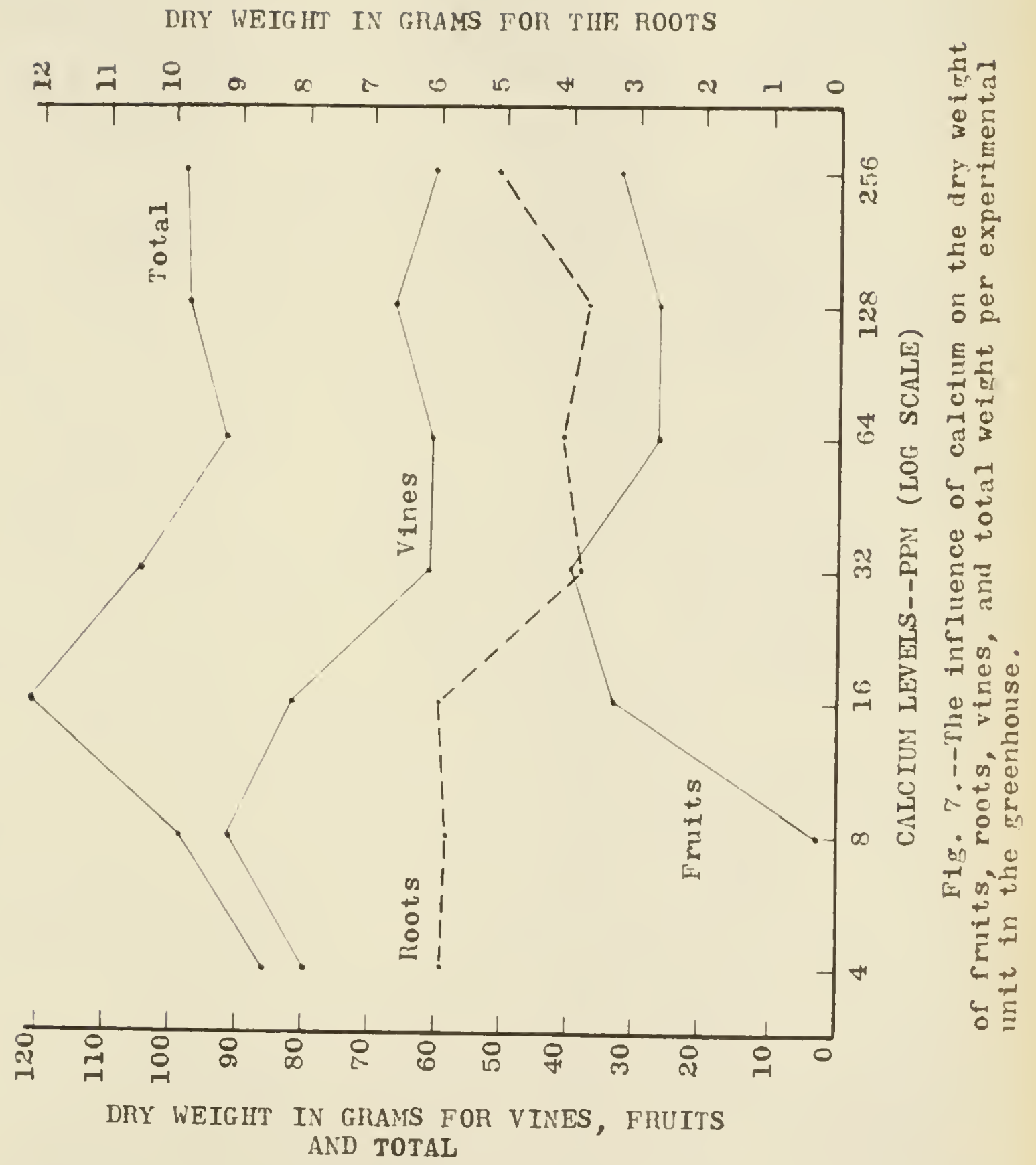


nitrogen remalned at all nitrogen levels after the excessive rains to give maximum growth in the early stages.

The percentage increase in early and total ylelds both in pounds and numbers are shown in Fig. 8. On an acre basis the application of 500 and 1,000 pounds of hydrated lime increased the number of early harvested watermelons by 80 and 129 respectively. These figures represent a percentage increase over the no lime treatment of 40 and 60 per cent respectively. On an acre basis the application of 500 and 1,000 pounds of hydrated lime increased the pounds of watermelons harvested early by $2,082.8$ and $3,222.6$ or 44 and 68 per cent respectively over the no lime treatment. The percentage increase in the number of pounds was slightly larger than the percentage increase in the actual number of watermelons. This indicates that the average weight per melon was slightly greater as a result of the lime treatments; however, statistical analysis based on the average welght per plot showed no significant difference. When the total yield of U.S. Number 1 watermelons per acre is considered, the application of 500 and 1,000 pounds of hydrated Iime increased the ylelds by 127 and 156 watermelons (39 and 48 per cent) respectively. A compar1son of the percentage Increase in the total number with the percentage increase in total pounds again indicates that the melons were larger in size, and this is supported by statistical significance based on the average weight per plot. It should be pointed out, however, that the average weight per 


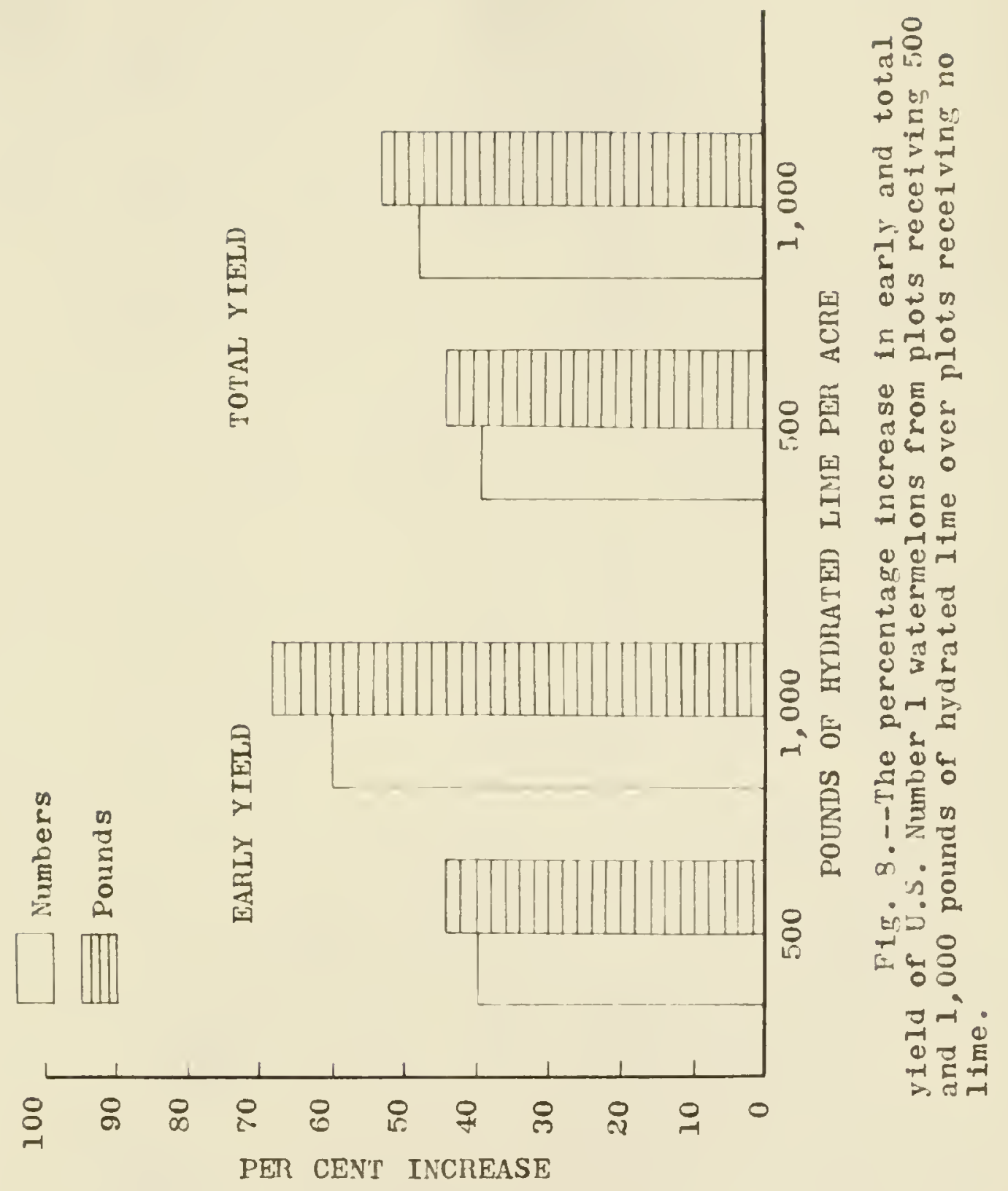


plot was based on unequal numbers; therefore, the analysis of variance may be biased.

Since these yield increases were obtained from rows spaced 15 feet apart and the hills 10 feet apart in the row, even greater total yields wore probable by spacing the rows or the hills closer together. In comercial watermelon fields rows are usualiy spaced 8 to 10 feet apart. Nettles and Halsey (53) reported significant increases in the number of watermelons produced as the number of hills per row were increased. Plants spaced 3 feet apart in rows 10 feet apart produced 1,260 marketable watermelons per acre, and plants spaced 12 feet apart in 10-foot rows produced 660 marketable watermelons per acre. The average weight did not differ significantly, but it tended to be greater at the wider spacings.

From the literature review and from examination of all soll and tissue analytical data it appears that the beneficial effects of calcium resulted from both an increased supply of calclum and pH changes, which may have directly or indirectly affected the availability of certain other elements. In general, investigators agree that the calcium to magnesium ratio in the soll should be in the range 6 to 10:1. Data in Table 11 and 31 indicate the calcium to magnesium ratios associated with the three treatments $(0,500$, and 1,000 pounds of hydrated lime per acre) were approximately $1: 1,6: 1$, and 15:1, respectively. Likewise, more favorable calcium to potassium ratios existed in the 
plots recelving lime. The importance of these ratios is exemplified by the data on the cation composition of the plants shown in Tables 24 through 30 . In general, the calcium content of the plant increased from 50 to 100 per cent In response to added calcium, and the potassium and magnesium content generally decreased. Moreover, Wilkins (83) pointed out that cucurbits accumulate large quantities of calclum, and suggested that it may be desirable to plant these crops on solls contalning an abundant supply of calcium.

Another undoubtably important factor contributing to the increased jields is the soll pH. From data in Table 11, It may be seen that the average pH corresponding to the three calclum levels were 4.9, 5.4, and 5.8. F1skell and co-workers $(23,24)$ have shown that toxic concentrations of aluminum lons are present in many of the Florlda solls, Including Kanapaha, with a low pH. Furthermore, 1t has been established that the rate of nitrification as well as organic matter decomposition is greatly influenced by the soll pH $(13,81)$.

Nitrogen had no significant effect on any of the yleld data from the field experiment. This may be attributed in part to excessive rainfall following both nitrogen applications. Over elght inches of rain fell the firgt 15 days following the inttial application of nitrogen. Over seven inches of raln fell the first 30 days following the second application of nitrogen. Data in Table 13 indicated 
that almost all of the nitrates and approximately 50 per cent of the potassium was leached from the upper elght inches of the soil by slightly more than eight inches of rainfall. Since ammoniun occupies a lower position in the Iyotrophic series than potasg1um it follows that at least 50 per cent of the ammonium nitrogen also was lost.

No definite relationship vas established between blossom-end rot and calcium treatments in the greenhouse or tho field. In all grcenhouse work using nutrient cultures, all the fruits set developed blossom-end rot.

Geraldson (26) observed that black-heart of celery, a calciur deficiency, occurred in nutrient solutions in the greenhouse regardless of the calclum levels. Black-heart was controlled by follar applications of 0.04 molar calcium chlorlde. A similar control has been developed for blossom-end rot of tomatoes (27).

In the exploratory work in the greenhouse with watermelons, a lowor inoldence of blossom-end rot was observed with treatments recelving follar sprays of 0.04 molar calcium chloride than from pots receiving no spray. This does not necessalily establish the disorder as a calclum deficiency; however. It does support the theory that blossom-end rot is a physlological disorder. This is further substantiated by the fact that a large percentage of the ovaries of plants grown in four and elght ppm calcium decayed beginning at the blossom-end even before the floral parts opened. It 1s suggested, therefore, that future examinations into the 
causes of blossom-end rot of watermelons may be more profItable if attempted under controlled environmental cond1tions.

The differential calcium treatments tested in the field did have an efrect on the rind thickness at the blossom-end of the watermel on but not on the average thickness of the top and bottom center of the rind. At the blossom-end the rind thickness decreased as the calcium levels were increased. At least two possible explanations exist for this: it is possible that calcium enhanced maturity; however, this is not supported by a significant Increase in the soluble solids, and observations have shown that frutts affected with blossom-end disorders tend to have a thick whitish rind at the blossom-end; therefore, increasing the calclum supply may have reduced these disorders. It should also be polnted out that the calclum content of the fruit generally increased linearly in response to calcium treatments.

\section{Sex Expression and Eruit Set}

Calcium treatments had a profound effect on sex expression in nutrient solutions containing relatively low amounts of calcium (Table 7). Plants grown in 13 liters of a solution containing $4 \mathrm{ppm}$ calctum had an average ratio of staminate to pistillate flowers of $27.79: 1$. When the calcium level was ralsed to $8 \mathrm{ppm}$ the ratio dropped to $8.74: 1$ and did not differ algnificantly as the calclum level was increased 
from 4 to $256 \mathrm{ppm}$; however, at the higher calcium levels the ratio tended to increase. From data presented in Tables 9 and 10 it may be assumed that this drastic increase in the flower ratio was due to elther a defielency of calcium. an excess of potassium and magnesium in the nutrient solution, or any comblnation of the latter with a calcium deficiency.

Apparentiy calciun concentrations greater than 8 ppm are necessary for fruit set. Since a large number of the ovaries of plants in solutions containing 4 and $8 \mathrm{ppm}$ calcium decayed, it is assumed that insufficient quantities of calclum were present for normal cellular development. The parabolic response in the number of fruits set to calcium treatments in the field may be explained on the basis that the liming applications enhanced vine growth thereby increasing the actual numbers of fruits set (Table 23).

\section{Chemical Analyses}

In the greenhouse experiment, the increase in the calcium content of the tips and frults was linear as the logarithms of the calcium treatments increased, however, a positive curvilinear response occurred in the leaves and roots. It is generally agreed that increasing the concentration of any element in the substrate usually results in increased absorption of that element by the plant $(44,59)$. The linear decrease in the potassium content of the leaves and roots probably was produced by a cation antagonism 
resulting from an increase in the calclum content. The fallure of potassium to decrease significantly in the tips and fruits may be explained on the basis that potassium is a very mobile element and occurs in relatively large quantities in areas of high metabolic activity $(48,50)$. Apparently cation antagonlsm between calcium and magnesium resulted in a linear decrease in tho magnesium content of the leaves and roots and a quadratic decrease in the tips and rruits.

Conversion of the data in Table 10 to equivalents per 100 grams Indicated that the calcium-equivalent increase in the plants at the varlous treatments was considerably greater than the accumulative equivalent decrease of potassium and magnestum. This may be attributed to Inactivation of much of the absorbed calctum by organtc acid precipitation thereby causing a continuous build-up of the total cation equivalents in the tissue as calcium increased in the substrate.

The influence of calcium and nitrogen on the average percentage of calclum, potassium, and magnesium of tissue samples from the fleld experiment is shown in Table 30. The linear increase in the calclum content in response to calcium applications occurred in the leares of both young and mature plants. The significant decrease in the calclum content of the leaves at the first sampling date as a result of nitrogen treatments falled to occur at the second sampling date. This may be the consequence of 
TABLE 30

THE AVFHAGE PERCENTAGE OF CALCIUM, POTASSTUM, AND MAGNESTUM ASSOCIATED WITH EACH CALCIUM AND EACH NITROGEN

LEVEL IN BOTH VINES AND FRUITS FROM THE FIELD EXPERIMENTA

\begin{tabular}{|c|c|c|c|c|c|c|}
\hline \multirow[t]{3}{*}{$\begin{array}{c}\text { Treatment } \\
\text { lovels }\end{array}$} & \multicolumn{3}{|c|}{$\begin{array}{c}\text { Composition of young } \\
\text { plants } \\
\text { (May 1, 1959) }\end{array}$} & \multicolumn{3}{|c|}{$\begin{array}{c}\text { Composition of mature } \\
\text { plants } \\
\text { (June 10, 1959) }\end{array}$} \\
\hline & \multicolumn{3}{|c|}{ Leaves } & \multicolumn{3}{|c|}{ Leaves } \\
\hline & $\overline{C a}$ & $\mathbf{K}$ & $\mathrm{Mg}$ & $\mathrm{Ca}_{\mathrm{a}}$ & $\mathbf{K}$ & $\mathrm{Mg}$ \\
\hline $\begin{array}{r}\text { Cal cium } \\
0\end{array}$ & 2.37 & 5.82 & 0.560 & 4.45 & 2.94 & 1.04 \\
\hline .500 & 3.85 & 5.33 & .454 & 8.59 & 1.99 & 0.99 \\
\hline 1,000 & 4.19 & 5.37 & .422 & 9.09 & 1.94 & 0.92 \\
\hline \multicolumn{7}{|l|}{ N1trogen } \\
\hline 60 & 3.70 & 5.41 & .494 & 7.42 & 2.38 & 1.01 \\
\hline 120 & 3.51 & 5.48 & .490 & 7.20 & 2.26 & 1.00 \\
\hline 180 & 3.20 & 5.64 & .152 & 7.50 & 2.24 & 0.94 \\
\hline
\end{tabular}

$\frac{\text { Tlps }}{\mathrm{Ca}_{2} \mathrm{~K}} \frac{\text { Tips }}{\mathrm{Cl}_{2} \mathrm{~K}}$

Calcium
0
1,000
$\begin{array}{lll}0.423 & 5.14 & 0.308\end{array}$
$.633 \quad 5.25 \quad .302$
$.791 \quad 5.26 \quad .296$
$\begin{array}{lll}.332 & 3.59 & .358\end{array}$
$.330 \begin{array}{ll}.3 .55 & .378\end{array}$
$\begin{array}{lll}0.280 & 2.81 & 0.402\end{array}$

Nitrogen

$\begin{array}{rrrrrrr}60 & .604 & 5.35 & .306 & .340 & 3.92 & .415 \\ 120 & .651 & 4.90 & .305 & .285 & 3.48 & .356 \\ 180 & 0.594 & 5.39 & 0.295 & 0.317 & 3.55 & 0.368\end{array}$

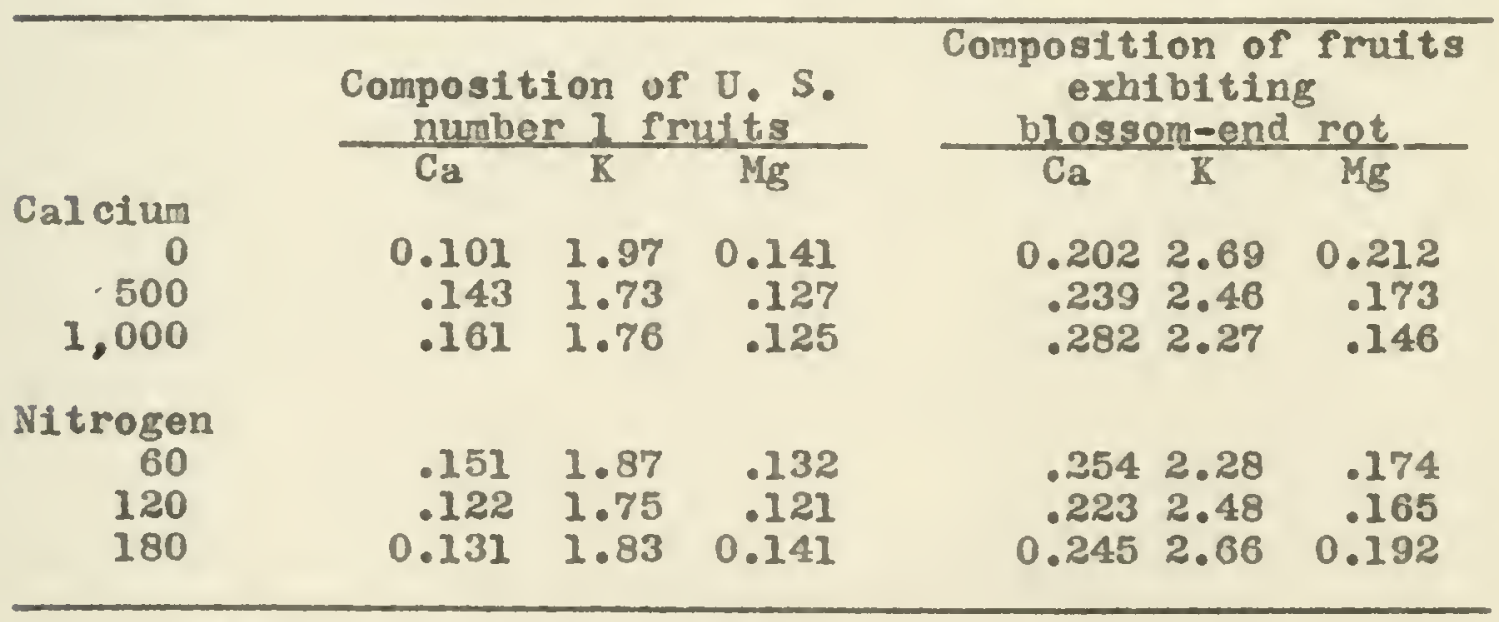


retardation in growth and less antagontsm between ammonium and calcium through leaching and oxidation of the ammonium. The concentration of calcium in the leavos, regardless of treatments, approximately doubled from the first to the second sampling dato. This 18 probably due to the precipitation of a large percentage of the calcium by certain organic acids.

The potassium content of the leaves at both sampling dates decreased in response to calcium applications; although, nitrogen had no effect on the potassium percentage of the leaves at elther sampling pertod. The leaf samples taken early in the season contained more than twice as much potassium on a percentage basis as those collected late in the season. Perhaps the best explanation of this is a combination of the mass action effect of the potassium applied early in the season with luxury consumption by the plant, and a dilution offect later in the season induced by heavy Vine growth.

The interaction between calctum and nitrogen on the magnesium content of the leares at the first sampling may be attributed to varying degrees of antagonism between the applied calcium and ammonium nttrogen when the level of elther was changed along with differential growth responses. At maturity this decrease in the magnesium percentage of the leaves was not statigtically slgnificant. The relatire increase in the magneglum percentage of the leaves as the season progressed, regardless of treatment, was approximately 
proportional to the relative increase in the calcium percentage.

The equivalent shift of the cation composition of the leaves in response to treatments at elther sampling time is in agreement with the greenhouse findings. That is, the calciun-equivalent increase in the tissue in response to calcium applications is much greater than the total magnesium and potassium equivalent decrease in the tissue.

The linear increase in the calcium content of the tips at the first sampling date in response to the calcium levels had disappeared by the second sampling date (Tables 21, 26, 30). Perhaps the best explanation of this is that tho young plants were in a more vigorous state of growth and assimilation than the mature plants. Also, this would account for the greater percentage of calcium in the tips of young plants.

Nelther the potassium nor the magnesium content in the tips at the first sampling date was significantly influenced by any treatment. Howover, nitrogen treatments decreased the potassium and magnesium content of the t1ps at the second sampling time. This may be attributed to a combination of a number of factors, including a retardation of the physiological activity of the merstimatic tissues, differential build up of ammontum lons in the tissue, and a dilution effect resulting from differential vine growth and fruit yields. 
In general, the normal fmults contained considerably less calcium, potassium, and magnestum than fruits exhibiting blossom-end rot. The most logtcal explanation of this is a dilution effect, since the mature fruits were approximately four to five times larger than the ones exhibiting blossomend $\operatorname{rot}(\mathrm{Table} 28,29,30)$.

The calcium content of both types of fruit samples Increased linearly in response to calcium treatments. The curvilinear response of calcium in the mature fruits to nitrogen may be attributod to antagonism between ammonium and nitrogen and differential vine growth.

The curvilinear interactions of the calclum and nitrogen treatments on the potassium content of both types of fruits may have resulted from mass action eifect of the hydrated lime, antagonism between amonium and potassium, and dilution due to differentlal growth responses (FIgs. 4 and 5). The same explanation may be given for the interaction of treatments on the magnesium content of fruits showing blossom-end rot (Fig. 6). 
Research was conducted in both the greenhouge and the field to evaluate the effects of varying calcium levels on vine growth, y1elds, quality, sex expression and fruit set, and the calcium, potassium, and magnesium content of plant tissues of the Charleston Gray variety of watermelons. In the greenhouse, plants grown in a basic nutrient solution contalning no calcium developed severe calcium deficiency symptoms and died within two weeks following transplanting. Plants grown in $4 \mathrm{ppm}$ calcium began to develop calclum deficlency symptoms in both the tops and roots three weeks following transplanting, and they grow increasingly more severe as the season progresged. Plants grown in $8 \mathrm{ppm}$ calclum showed no deficlency symptoms in the tops, although slight deficlency symptoms were present in the roots. Plants grew normally in nutrient solutions ranging from 16 to 256 ppm calcium.

The leaves of deficient plants were dark green in color, moderately cupped under at the margins, and severely restricted especlally at the apex forming a more circular type leaf, and the vine laterals were short and very numerous. The root systems of calcium deficient plants were short, dense, very numerous, and often dark at the apex indicating death. 
The dry weight of the vines and the roots, when analyzed separately, decreased linearly as the logarithms of the calcium concentration increased in the nutrient solution. However, total dry welght (vines, roots and fruit) did not differ significantly among calcium levels.

In the fleld experiment testing three levels of calcium $(0,500$, and 1,000 pounds of hydrated lime per acre) and three levels of nitrogen $(60,120$, and 180 pounds per acre), the dry welght of early vine growth increased significantly in a linear pattern in response to increasing calcium levels. N1trogen did not affect early vine growth or any other growth measurements taken in this experiment. Explanations are suggested based on soll test and rainfall data.

There was a significant linear increase in early and total yield in both pounds and numbers of marketable watermelons as a result of increased calcium levels. The average welght per melon of the early yleld was not affected by treatments; howerer, the average weight per melon of the total jleld was increased significantig by increasing the calcium levels. The environmental factors possibly responsible for these yield increases are discussed. It appeared that the beneficlal effects of calcium resulted from both an Increased supply of calclum and pH changes whlch may have directly or Indirectly affected the avallability of other elements. 
Calcium levels in the greenhouse nutrient solutions had a profound effect on sex expression and fruit set at the lower concentrations. The ratio of staminate to pistillate flowers in solutions contalning $4 \mathrm{ppm}$ calcium was 27.79:1. When the calcium concentration was increased to $8 \mathrm{ppm}$ the flower ratio dropped to $8.74: 1$, and it did not differ significantly as the calcium levels were increased to $256 \mathrm{ppm}$. At least $16 \mathrm{ppm}$ of calcium in the nutrient solutions were necessary for fruit set. In the field the total number of fruits set increased in a quadratic fashion as the calcium levels were increased. Nitrogen had no effect on the numbers of fruit set in the field. A large percentage of the ovaries produced by plants grown in nutrient solutions contalning 4 or 8 ppm calcium turned dark brown to black in color beginning at the blossom-end, even before the floral parts opened. All fruits set in the greenhouse, regardless of the admixture of the nutrient solutions, developed blossom-end rot within three weokg after flowering. The percentage of blossom-end rot in the fleld experiments could not be associated with troatments. However, the rind thickness at the blossom-end of marketable frults decreased linearly as the calcium treatments increased.

Analyses of data from three fertility experiments during the 1958 season revealed that the occurrence of blossom-end rot could be assoclated with the soll profile characterigtiog but not with the different fertility treatments. 
In the field experiment, the different fertility treatments tested resulted in no significant influence on the soluble sugars, hollow-heart, whtte-heart, or average thickness of the rind measured at the center of the frutt. Analyses of tissue samples from various plant parts indlcated that watermelons absorb relatively large quant1ties of calclum, potassium, and magnesium. The greatest concentration of calcium or magnesium occurred in the older leaves with the percentages docreasing in the following order: basal leaves, mid-leaves, tips, stems and frults. The potassium percentages decreased in the following order: fruits, stems, t1ps, leaves.

Analyses of the tips, leaves, roots and frutts from the greenhouse experiment indicated, In general, that as the calcium concentration was increased logarithmically in the nutrient medium the calclum content in the tigsues increased and the potassium and magnesium content decreased. The Increase in the percentage of calclum in the tips and fruits was linear and the increase in the calcium content of the leaves and roots was curvilinear, when measured against the logarithms of the calclum concentrations in the nutrient solution. Stgniflcant negative linear regressions In the potassium content occurred in the 1 eaves and roots but not in the tips and fruits in response to calcium levels. The negative regression in the magnesium content induced by the calcium levels was linear in the roots and frults and quadratic in the leaves and tips. 
Analjses of tip and leaf. samples from both young and mature watemelon plants from the fleld indicated that the calcium percentage generally increased, and the magnesium and potassium content decreased as the calcium supply was increased in the so11. The influence of nitrogen on the cation composition of the leaf and tip samples was at variance for the two sampling dates; however, any significant effect of nitrogen treatments on the cation composition of the tissues generally resulted in a decrease of the particular element as the nitrogen levels were increased in tho soil.

On a percentaze basis the calcium and magnesium content of the leaves of mature plants, regardless of treatment, was approximately double that of the leaves of the soung plants, while the potassium content was approximately 50 per cent less in the older plants. The calclum or potassium percentage of the tips of mature plants was 50 per cent 1ess, while the magnesium percentage remained falrig constant from the first to the second sampling. Analjses of U. S. Number 1 watermelons and those exhibiting blossom-end rot revealed that the calcium content generally increased and tho potassium and magnesium content generally decreased in response to increasing calcium lovels. Increasing nitrogen levels, however, resulted in a reduction of both the calcium and magnesium content of the U. S. Number 1 watermelon fruits. The magnesium content of the fruits 
exhlbiting blossom-end rot and the potassium content of both types of fruits was influenced by calcium and nitrogen interactions.

The calcium, potassium, and magnesium content of the U. S. Number 1 fruits were generally lower than the concentration of these cations in the frults exhlbiting blossomend rot.

It is believed that results of this study may be of value in evaluating and explaining tho occurrence of certain physiological disorders and poor growth and yleld often obtained in many of the commercial watormelon flelds in North Central Floricia. 


\section{REFERENCES CITED}

1. Andrews, W. B. 1937. The effect of ammontum sulfate on the response of soybeans to lime and artificial innoculation and the energy required of soybean nodule bacteria. Jour. Amer. Soc. Agron. 29:681-689.

2. Anonymous. 1954. Soll survey, Alachua County, Florida. USUA and Fla. Agr. Expt. Sta. 233-235.

3. Arnon, D. I. 1943. Mineral nutrition of plants. Ann. Rev. Biochem. 12:493-528.

4. Baver, L. D.' 1956. Soll Physics, New York: John Wlley \& Sons, Inc. 3rd. Ed.

5. and Hall, N. S. 1937. Colloidal properties of soil organic matter. Mo. Agr. Expt. Sta. Res. Bull. 267.

6. Bernstein, L. and Hayward, H. E. 1958. Physlology of salt tolerance. Ann. Rer. Plant Phys1ol. 9:1-25.

7. Blddulph, 0., Cory, R., and B1ddulph, Susann, 1959. Translocation of calciur in the bean. Plant Physiol. $34: 512-519$.

8. Blodgett, F. H. 1915. Plant pathology and physiology. Texas Agr. Expt. Sta. Ann. Rept. 18.

9. Bonner, James and Galston, Arthur W. 1952. Princlples of Plant Phys10logy. San Francisco: W. H. Freeman and Co.

10. Bradley, G. A. and Fleming, J.W. 1959. Fertilization and foliar analysis studies on watermelons. Ark. Agr. Expt. Sta. Bull. 610.

11. Brantley, B. B. 1958. Effects of nutrition and other factors on flowering. frulting, and quality of watermelons and muskmelons. Unpublished Dissertation, Purdue Univ., Dept. of Hort.

12. Breland, H. L. 1957. Methods of analyses using soil testing. Fla. Agr. Expt. Sta. Dept. Solls Memo. Rept. No. 58-3. 
13. Burrus, R. H. 1959. N1trogen nutrtion. Ann. Rev. Plant Phys1ol. 10:301-328.

14. Carolus, R. L. and-Lorenz, 0. A. 1938. The interrelation of manure, lime, and potash on the growth and maturity of the muskmelon. Proc. Amer. Soc. Hort. Sc1. 36:518-522.

15. Cochran, W. G. and Cox, Gertmude M. 1957. Exper1mental Designs. Now York: Wiley Publications in Stat1st1es.

10. Cooper, H. P. 1950. Effects of energy properties of some plant nutrients on avallability, on rate of absorption, and on intensity of certain oxidationreduction reactions. Soll Sc1. 69:7-39.

17. Cunningham, Clyde R. 1939. Frult set in watermelons. Proc. Ameri. Hort. Sc1. 37:811-814.

18. Dearborn, R. B. 1936, Nitrogen nutrition and chemical composition in relation to growth and fruiting of the cucumber plant. Cornell UnIv. Agr. Expt. Memo. 192 .

19. Duncan, D. B. 1955. Multiple range and multiple F test. B1ometrics. $11: 1-42$.

20. Eisenmenger, W. S. and Kucinsk1, K. T. 1939. Magnesium requírements of plants. Mass. Agr. Expt. Sta. Ann. Rept. 10.

21. Epste1n, E. 1956. Mineral nutrition of plants; mechanisms of uptake and transport. Ann. Rev. Plant Physiol. 7:1-24.

22. Everett, P. H. and Geraldson, C. M. 1958. Fert1lizer requirements of watermelons. Fla. Agr. Expt. Sta. Ann. Rept. 326-328.

23. Flskell, J. G. A., Hortenstine, C. C., Carver, H. I.., and Lundy, H. W. 1958. Aluminum studies on some north and central Florida solls. The Soll and Crop Sc1. Soc. of Fla., Proc, 18:166-178.

24. and Robertson, W. K. 1957. Comparison of broadcast and row fertilization for potatoes on Kanapaha fine sand. Fla. State Hort. Soc. 70:96-103.

25. Fried, M. and Peech, M. 1946. The comparative effects of gypsum upon plant growth in acid solls. Jour. Amer. Soc. Agron. 38:614-623. 
26. Geraldson, C. M. 1957. Symptoms of nutritional disorders in vegetable plants. Fla. Agr. Expt. Sta. Ann. Rept. 296.

27. 1957. Control of blossom-end rot of tomatoes. Proc. Amer. Soc. Hort. Sc1. 69:309-317.

28. Hall, C. B., Nettles, V. F., and Dennison, R. A. 1951. Fertilizer requirements for watermelons. Fla. Agr. Expt. Sta. Progress Rept. (Msc.).

29. $\longrightarrow$ and $\longrightarrow$ 1955. Fertilizer requirements for watermelons. Fla. Agr. Expt. Sta. Ann. Rept. 113.

30. Hall, W. C. 1949. Effects of photoperiod and nitrogen supply on growth and reproduction in the gherkin. P1ant Physiol. 24:753-769.

31. Hardh, J. E. 1957. On the calcium uptake of glasshouse cucumbors. Maataloust Aikakausk. 29:238-242 (Hort. Abs. Vol. 28, No. 1419).

32. Hartman, John D. and Gaylord, F. C. 1940. So11 a cidity for muskmelons and sweetpotatoes on sand. Proc. Amer. Soc. Hort. Sc1. 37:841-845.

33. Hartman, John D, and Gaylord, F. C. 1941. Soll acidity for watermeions on sand. Proc. Amer. Soc. Hort. Sc1. $38: 623-625$.

34. Hartwel1, B. L. and Damon, S. C. 1914. The comparative effect oil different kinds of plants of liming an acid soil. R. I. Agr. Expt. Sta. Buil. 160.

35. Hasler, A. and Maurizio, A. 1951. The influence of various nutrients on budding, nector secretion, and yleld of seeds of honey plants, especially winter rape (Brasster napus). Schweiz. Blenen-Z. 74:208-219 (C. A. Vol. 49, No. 4091g).

36. Heslop, Harrison J. 1957. The Experimental Modifications of Sex Expression in Flowering Plants. Biol. Review. 32:38-90.

37. Hoagland, D. R. and Arnon, D. I. 1950. The Waterculture Metiod for Growing Plants without Soll. Calif. Agr. Expt. Sta. C1r. 347.

38. Holmes, R. S. 1943. Copper and zinc content of certain United States soils. Soil Sci. 56:359-370. 
39. Horn, G. C. 1955. Some factors affecting the accuracy of the flame spectrophotometric determination of magnesium in so11s. Unpybliched Dissertation. Univ. of F1a.

40. Jamison, F. S. and Nettles, V. F. 1940. Phenolog1cal studies on truck crops in Florida. Fla. Agr. Expt. Sta. Ann. Rept. 86-87.

41. Klmbrough, W. D. 1930. The effect of fertilizer on the quality of watermelons. Plant Phys1ol. 5:373-385.

42. Knott, J. E. 1957. Handbook for Vegetable Growers. New York: John Wiley and Sons, Ino. 36.

43. Langston, Kuble. 1956. Radiolsotopes in plants. Proc. Amer. Soc. Hort. Sc1. 68:370-376.

44. Lat1es, George G. 1959. Active transport of salt into plant tissue. Ann. Rev. Plant Phys101. 10:87-112.

45. Loehwing, W. F. 1938. Physlological aspects of sex In anglosperms. Bot. Rev. 4:581-625.

46. Marshal1, C. E. 1948. Ionization of calcium from soll collolds and its bearling on soll-plant relationships. Soll Sol. 65:57-68.

47. Mazaeva, M. M. 1957. Effect of magnestum fertilization and its role in plants. Botan. Zhur. 42:571-582 (c. A. Vol. 51, No. 1842g).

48. Meyer, B. S. and Anderson, D. B. 1952. Plant Physiology. New York: D. Van Nostrand Company, Ino. Second Edition.

49. Meyers, H. E. 1937. Phystochemical reactions between organic and inorganic soll collolds as related to aggregate formation. Soll Sol. 44:331-359.

50. Miller, Edwin C. 1938. Plant Physiology. New YorkLondon: MCGraw-H11l Book Company, Ine.

51. Minina, E. G. 1938. On the phenotypical modification of sex characters in higher plants and other external factors. C. R. Acad. Sc1. USSR 21:298-301 (C. A. Vol. 33. No. 4292).

52. Morazov, A. S. 1938. Effect of sodium chloride and sodium sulfate on sugar content of melons.' Compt. Rend. Acad. So1. USSR 21:279-281 (C. A. Vol.33, No. 3850).

53. Nettles, V. F. and Halsey, I. H. 1958. Fertilizer Requirements of watermelons. Fla. Agr. Expt. Sta. Ann. Rept. 172-173. 
54. Nightingale, G. T. 1937. The nitrogen nutrition of green plants. Bot. Rev. 3:85-174.

55. Overstreet, Roy and Jacobson, Louls. 1952. Mechanisms of Ion absorption by roots. Ann. Rev. Plant Physiol. $3: 189-206$.

56. Parris, G. K. 1952. Diseases of watermelons. Fla. Agr. Expt. Sta. Bull. 491.

57. Patterson, D. R. and Smith, 011ver E. 1958. H1gh potash rates boost watermeion yellds. Better Crops $42: 12-15$.

58. Peech, M. and Bradfield, R. 1943. The effect of lime and magnesia on the soli potassium and on the absorption of potassium by planis. Soll Sc1. 55:37-48.

59. Plerro, H. I. and Bower, C. A. 1943. Potassiun absorption by plants as affected by cationic relationships. Sol1 Sc1. 55:23-36.

60. Porter, D. R., Blsson, C. S., and Allinger; H. W. 1940. Factors affecting the total soluble solids, reducling sugars, and sucrose in watermelons. Hilgardia 13:3166.

61. Purv1s, E. R. and Ruprecht, R. W. 1937. Cracled stem of celery. Pla. Agr. Sxpt. Sta. Bull. 307.

62. Reynolds, C. W. and Stark, F. C. 1953. Growth and frulting responses of cucumbers to varying levels of $\mathrm{Ca}, \mathrm{K}, \mathrm{Mg}$, and $\mathrm{N}$ in sand culture. Proc. Assoc. of So. Agr. Workers. 133-134.

63. Richards, F.J. 1944. Mneral nutrition of plants. Ann. Rev. Blochem, 13:611-630.

64. Sabinin, D. A. 1937. La nutrition minerale comme facteur of mophogenes. Bull. Soc. Nat. Moscow, Sect. Biol. 46:67-76 (C. A. Vol. 31, No. 5843).

65. Schmehl, W. R., Poech, Michael and Bradfield, Richard. 1950. Causes of poor growth of plants on acid solls and beneficial effects of liming: I Evaluation of factors responsible for acid--501l injury. Soll Sel. $70: 393-410$.

66. Sharples, G. C. and Foster, R. E. 1958. The growth and composition of cantaloupe plants in relation to the $\mathrm{Ca}$ saturation percentage and N levels of the soll. Proc. Amer. Soc. Hort. Sc1. 72:417-425. 
67. Shear, C. B. and Crane, H. L. 1954. Inorganic nutrition of plants with special reference to interaction among elements. Unpublished Manuscript, $1-40$.

68. and Meyers, T. A. 1946. Nutrient element balance: A fundamental concept in plant nutrition. Proc. Amer. Soc. Hort. Sc1. 47:239-248.

69. and ment balance: response of tung trees 1953 . Nutrient eleculture to potassium, magnssium, calctum, and thelr interactions. USDA Tech. Bul1. No. 1085.

70. Smith, G. L, and Mohr, II. C. 1953. Effect of different nutrient level's on the yleld of marketable black dlamond watemelons, 1949-52. Texar Agr. Expt. Sta. Progresg Rept. ivo. 1589.

71. Staker, E. $\mathrm{V}$. and Cummings, R. W. 1941. The Influence of zinc on the productivity of certain New York peat so11s. Soll Sc1. Soc. Amer. Proc. 6:206-214.

72. Stark, F, C. and Haut, Irvin C. 1958 minoral nutrient requirements of cantaloupes. Md. Agr. Fxpt. Sta. Bull.
A-93.

73. Stuckey, H. P. 1924. Watemelons. Georgla Agr. Expt.
Sta. Buil. 143.

74. Taylor, George A. and Smith, Cyr11 B. 1957. The uso of plant analysis in the study of blosson-end rot of tomatoes. Proc. Amer. Soc. Hort. Sc1. 70:341-349.

75. Taubenhaus, J. J. 1921. Blossom-end rot: division of plant pathology and phys1ology. Texas Agr. Expt. Sta.
Ann. Rept. 17-19.

76. Thompson, A. E. 1955. Methods of producing rirst generation hybrid in seed spinach. Cornell Agr. Expt.
Sta. Mez. 336 .

77. T1beau, M. E. 1936. Llme factor in util1zation of minerals by hemp. Plant Phys101. 11:731-74?.

78. Tiedjens, V. A. 1923. Sex ratios in cucumber rlowers as affected by different conditions of soil and 11 fht. Jour. Agr. ies. 36:721-746.

79. U1rich, Albert. 1952. Pbystologlcal bases for assessing the nutritional requirements of plants. Ann. Rer. Plant. Physiol. 3:207-228. 
80. USDA. 1958. Vegetables-fresh market annual summary acreage, production and value of principle commerclal crops by season groups and states with comparisons,

81. Waksman, Selman A. 1952. Soll Microbiology. Now York: John Wiley \& Sons.

82. Walker, M. N. 1931. Investigation and control of diseases of watermelons. Fla. Agr. Expt. Sta. Ann. Rept. 115.

83. Wilkins, Louis K. 1917. High calcium content of some cucurbit vines. N. J. Agr. Expt. Sta. Bull. 310.

84. Wood, J. G. 1954. Nitrogen metabolism of higher plants. Ann. Rev. Plant Physiol. 5:1-22.

85. Woodard, 0t1s. 1954. Factors influenolng whiteheart in watermelons. Atlantic Coast Line Agr. and Livestock Topics. 6 : (Apri1) 3-4.

86. Wright. K. E. 1937. Iffects of phosphorus and I1me in reducing aluminum toxicity of acid solls. Plant Physiol. 12:173-181. 
APPENDIX A

DETAILED SOIL TEST RESULTS BY PLOT 
TABLE 31

THE $\mathrm{pH}$ AND THE POUNDS PER ACRE OF AVAILABLE NUTRIENTS FROM SOIL SAMPLES TAKEN IN WATERMELON BEDS FROM ALL FIELD PLOTS ON APRIL 1, 1959

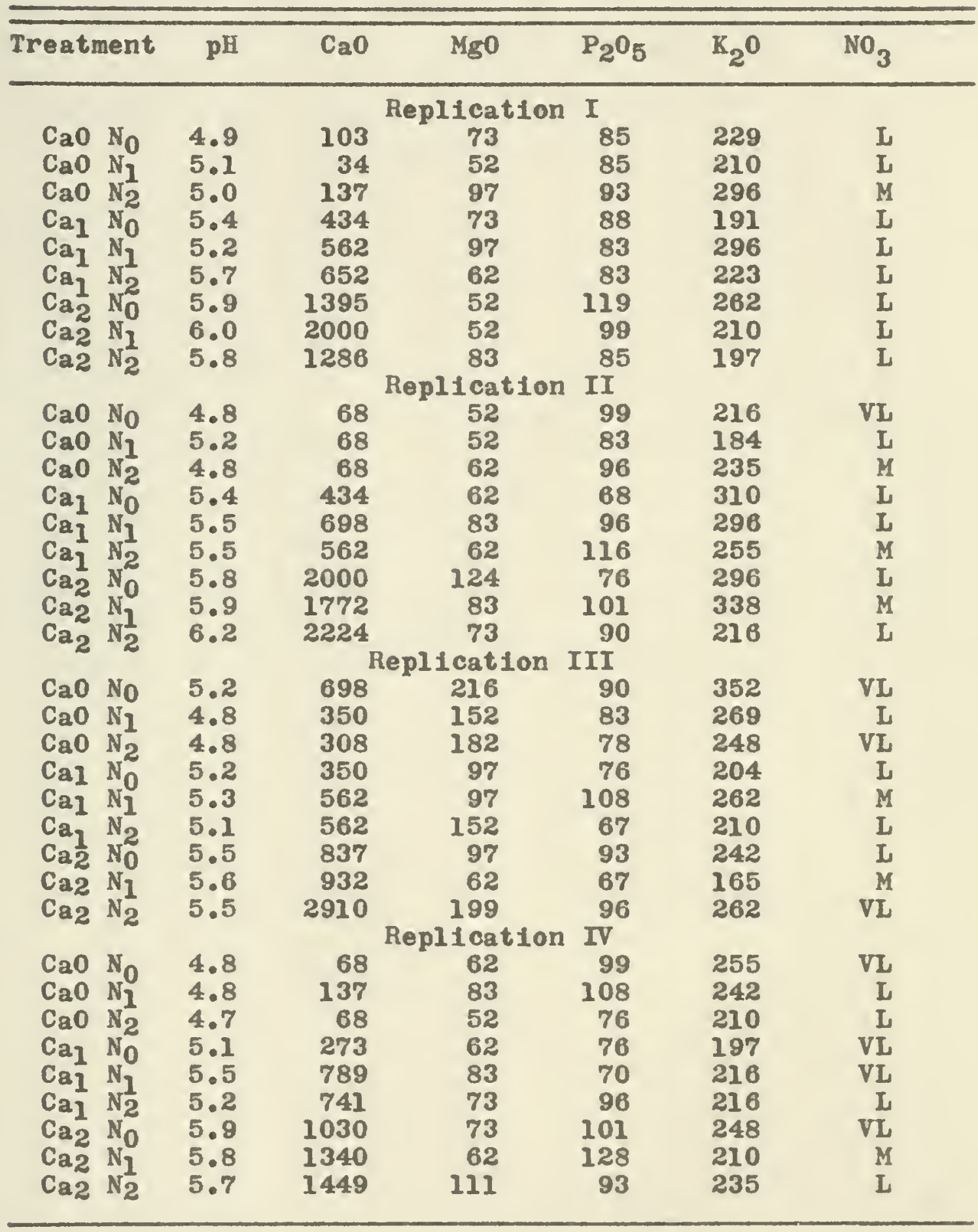


TABLE 32

THE $p H$ AND THE POUNDS PER ACRE OF AVA ILABLF NUTRIENTS FHOM SOIL SAMPLES TAKEN ON EACH SIDE OF THE

BED FROM ALL PLOTS ON APRIL 1, 1959

\begin{tabular}{|c|c|c|c|c|c|c|}
\hline Treatment & $\mathrm{pH}$ & $\mathrm{CaO}$ & MgO & $\mathrm{P}_{2} \mathrm{O}_{5}$ & $\mathbf{K}_{2} \mathbf{O}$ & $\mathrm{NO}_{3}$ \\
\hline & & & Replication & I & & \\
\hline $\mathrm{CaO} \mathrm{N}_{0}$ & 4.7 & 34 & 41 & 54 & 30 & I \\
\hline $\mathrm{CaO} \mathrm{N}_{1}$ & 4.9 & 68 & 52 & 55 & 47 & I \\
\hline $\mathrm{CaO}_{2} \mathrm{~N}_{2}^{1}$ & 4.7 & 34 & 62 & 51 & 65 & $M$ \\
\hline $\mathrm{Ca}_{1} \mathrm{~N}_{0}$ & 5.1 & 137 & 62 & 46 & 65 & $\mathrm{M}$ \\
\hline $\mathrm{Ca}_{1} \mathrm{~N}_{1}$ & 5.1 & 308 & 97 & 49 & 59 & M \\
\hline $\mathrm{CaI}_{1}^{2} \mathrm{~N}_{2}^{2}$ & 4.8 & 68 & 52 & 52 & 59 & M \\
\hline $\mathrm{Ca}_{2} \mathrm{~N}_{0}$ & 5.2 & 239 & 62 & 52 & 47 & $\mathrm{M}$ \\
\hline $\mathrm{Ca}_{2} \mathrm{~N}_{1}$ & 5.3 & 239 & 73 & 61 & 24 & M \\
\hline \multirow{2}{*}{$\mathrm{Ca}_{2} \mathrm{~N}_{2}^{1}$} & 5.0 & 103 & 41 & 49 & 59 & I \\
\hline & & & Replication & II & & \\
\hline $\mathrm{CaO} \mathrm{N}_{0}$ & 5.0 & 34 & 31 & 46 & 41 & VI \\
\hline $\mathrm{CaO}_{\mathrm{a}}$ & 4.9 & 68 & 41 & 54 & 41 & I \\
\hline $\mathrm{CaO} \mathrm{N}_{2}$ & 4.8 & 34 & 31 & 45 & 47 & VI \\
\hline Cal $N_{0}$ & 5.0 & 68 & 41 & 46 & 35 & I \\
\hline $\mathrm{Ca}_{1} \mathrm{~N}_{1}$ & 5.1 & 137 & 97 & 44 & 47 & I \\
\hline $\mathrm{Ca}_{1} \mathrm{~N}_{2}^{1}$ & 4.9 & 68 & 41 & 51 & 35 & M \\
\hline $\mathrm{Ca}_{2} \mathrm{~N}_{0}$ & 5.0 & 171 & 83 & 43 & 53 & L \\
\hline $\mathrm{Ca}_{2} \mathrm{~N}_{1}$ & 5.0 & 137 & 62 & 46 & 53 & I \\
\hline \multirow[t]{2}{*}{$\mathrm{Ca}_{2} \mathrm{~N}_{2}^{1}$} & 5.1 & 103 & 41 & 48 & 41 & VL \\
\hline & & & Replication & III & & \\
\hline $\mathrm{CaO} \mathrm{N}_{0}$ & 5.2 & 652 & 253 & 44 & 152 & I \\
\hline $\mathrm{CaO} \mathrm{N}_{1}$ & 4.8 & 137 & 138 & 51 & 127 & VI \\
\hline $\mathrm{CaO} \mathrm{N}_{2}$ & 4.9 & 239 & 216 & 48 & 172 & VI \\
\hline $\mathrm{C}_{\mathbf{a}} \mathrm{N}_{0}$ & 5.0 & 103 & 97 & 49 & 102 & L \\
\hline $\mathrm{Ca}_{7} \mathrm{~N}_{1}$ & 5.0 & 171 & 83 & 51 & 47 & vi \\
\hline $\mathrm{Ca}_{1}^{1} \mathrm{~N}_{2}^{1}$ & 4.9 & 205 & 166 & 45 & 77 & VL \\
\hline $\mathrm{Ca}_{2} \mathrm{~N}_{0}$ & 4.8 & 103 & 62 & 54 & 65 & VL \\
\hline $\mathrm{Ca} 2 \mathrm{~N}$ & 4.8 & 103 & 41 & 48 & 41 & VL \\
\hline \multirow[t]{2}{*}{$\mathrm{Ca}_{2} \mathrm{~N}_{2}^{1}$} & 4.9 & 434 & 166 & 44 & $9 \overline{0}$ & I \\
\hline & & & Replication & IV & & \\
\hline $\mathrm{C}_{3} \mathrm{O} \mathrm{N}_{0}$ & 4.7 & 34 & 52 & 55 & 53 & VI \\
\hline $\mathrm{CaO} \mathrm{N}_{1}$ & 4.7 & 68 & 52 & 60 & 59 & L \\
\hline $\mathrm{CaO}_{2} \mathrm{~N}_{2}$ & 4.8 & 68 & 62 & 60 & 24 & VI \\
\hline $\mathrm{Ca}_{1} \mathrm{~N}_{\mathrm{n}}$ & 4.9 & 68 & 31 & 55 & 30 & VL \\
\hline $\mathrm{Ca}_{1} \mathrm{~N}_{1}$ & 4.9 & 137 & 83 & 49 & 59 & VL \\
\hline $\mathrm{Ca}_{1} \mathrm{~N}_{2}^{\frac{1}{2}}$ & 5.0 & 68 & 41 & 55 & 35 & VL \\
\hline $\mathrm{Ca}_{2} \mathrm{~N}_{0}$ & 5.1 & 103 & 41 & 57 & 30 & VI \\
\hline $\mathrm{Ca}_{2} \mathrm{~N}_{1}$ & 5.1 & 103 & 52 & 49 & 30 & VL \\
\hline $\mathrm{Ca}_{2} \mathrm{~N}_{2}$ & 4.9 & 103 & 73 & 51 & 41 & VI \\
\hline
\end{tabular}


APPENDIX B

ANALYSES OF VARIANCE TABLES 


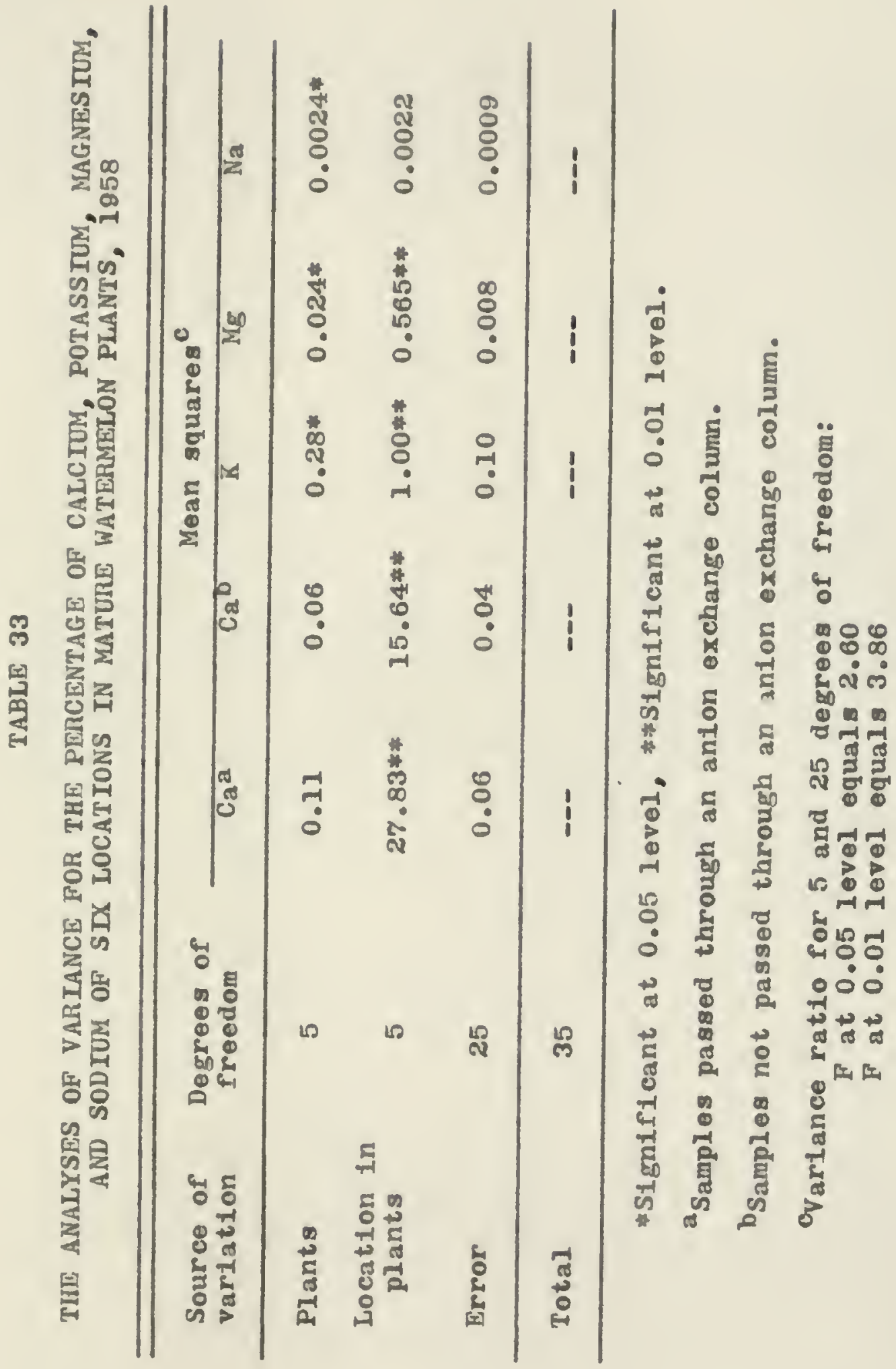




\section{TABLE 34}

THE ANALYSES OF VARIANCE OF THE OVEN DRY WEIGHTS OF VINES, ROOTS, AND TOTAL WEIGHT (VINES, ROOTS, AND FRUT'S) OF GREENHOUSE EXPERIMFNT

\begin{tabular}{|c|c|c|c|c|}
\hline \multirow[b]{2}{*}{$\begin{array}{l}\text { Source of } \\
\text { variation }\end{array}$} & \multirow[b]{2}{*}{$\begin{array}{l}\text { Degrees of } \\
\text { freedom }\end{array}$} & \multicolumn{3}{|c|}{ Mean squares ${ }^{2}$} \\
\hline & & Vines & Roots & $\begin{array}{l}\text { Total wolght } \\
\text { (vines, roots, } \\
\text { frutts) }\end{array}$ \\
\hline Replication & 3 & 160.7 & 1.66 & 440.9 \\
\hline $\mathrm{Ca}_{\mathrm{a}}$ levels $\mathrm{b}$ & 6 & 617.9 & 4.05 & 496.5 \\
\hline Ininear & 1 & $2340,6 \neq$ & $9.29 *$ & 6.5 \\
\hline Quadratic & 1 & 33.7 & 4.31 & 917.1 \\
\hline Cubic & 1 & 434.4 & $6.93 *$ & 1229.1 \\
\hline Residual & 3 & 224.6 & 1.26 & 277.8 \\
\hline Error & 18 & 135.3 & 1.37 & 304.7 \\
\hline Total & 27 & $-\infty$ & $-\infty$ & $-\infty$ \\
\hline
\end{tabular}

*Significant at 0.05 level, **ignificant at 0.01 lovel.

avariance ratio for 1 and 18 degrees of freedom:

$F$ at 0.05 level equals 4.41

$F$ at 0.01 level equals 8.28

beffects were determined by using $\log x$ as the Independent variable, where $x$ equals the concentration of oalcium in the nutrient solution in ppm. 


\section{TABLE 35}

THE ANALYSES OF VARTANCE FOR TLE NUMBER OF STAMINATE, PISTILLATE, AND RATIO OF STAMINATE TO PIS-

TILLATE FLOWERS PRODUCED IN THF.

GREENHOUSE EXPERTMENT

Source of

variation

Degrees of

Mean squares

freedom

Staminate P1st1llate

$S: P$ ratio

Replication

3

1.72

0.44

0.11

Ca levels

6

$8.89 * *$

$3.23 * *$

$3.04 \%$

Error

18

0.62

0.22

0.16

Total

27

$-\infty$

$--$

$-\infty$

**Significant at 0.01 level.

Variance ratio for 6 and 18 degrees of freedom:

$F$ at 0.05 level equals 2.66

$F$ at 0.01 level equals 4.01 . 


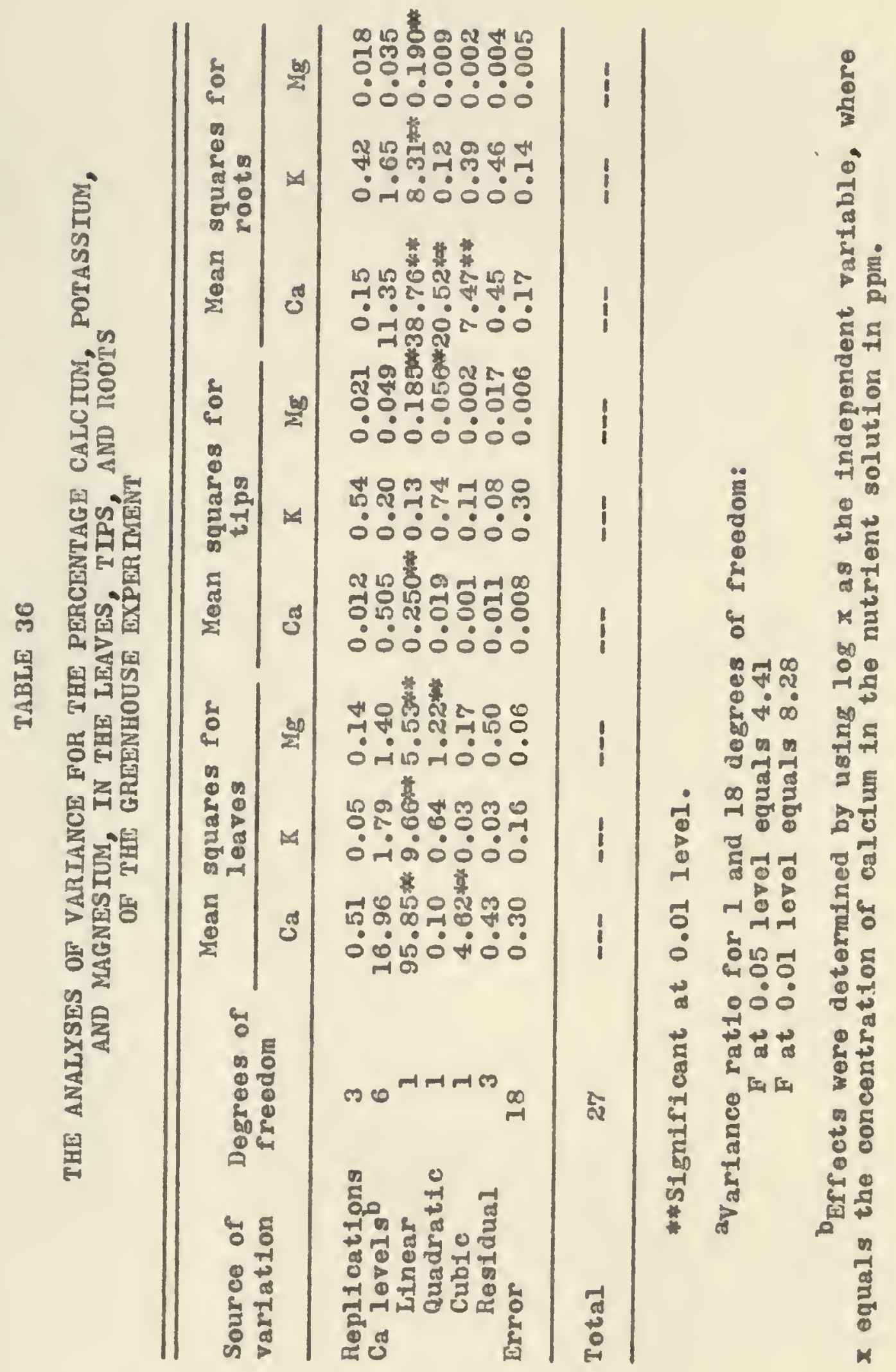


THE ANALYSES OF VARIANCE FOR CALCIUM, POTASSIUM, AND MAGNESIUM IN THE FRUITS OF THE GIREENHOUSE EXPIR DMENT

\begin{tabular}{lllll}
\hline $\begin{array}{c}\text { Source of } \\
\text { variation }\end{array}$ & $\begin{array}{c}\text { Degrees of } \\
\text { freedom }\end{array}$ & & \multicolumn{3}{c}{ Mean squares } \\
\hline
\end{tabular}

\begin{tabular}{lclll} 
Replications & 3 & 0.001 & 0.10 & 0.002 \\
Ca levelsb & 4 & 0.037 & 0.14 & 0.010 \\
Linear & 1 & $0.141 *$ & 0.05 & $0.040 *$ \\
Quadratic & 1 & 0.003 & 0.01 & 0.000 \\
$\quad$ Cubic & 1 & 0.000 & 0.38 & 0.001 \\
$\quad$ Hesidual & 1 & 0.004 & 0.04 & 0.000 \\
Error & $12^{2}$ & 0.001 & 0.23 & 0.002 \\
\hline Total & 19 & -- & - & - \\
\hline
\end{tabular}

* Significant at 0.01 level.

avariance ratio for 1 and 12 degrees of freedom:

$F$ at 0.05 level equals 4.75

F at 0.01 level equals 9.33

${ }^{b}$ Effects were determined by using $\log x$ as the independent variable, where $x$ equals the concentration of cal ofum in the nutrient solution in $\mathrm{ppm}$. 


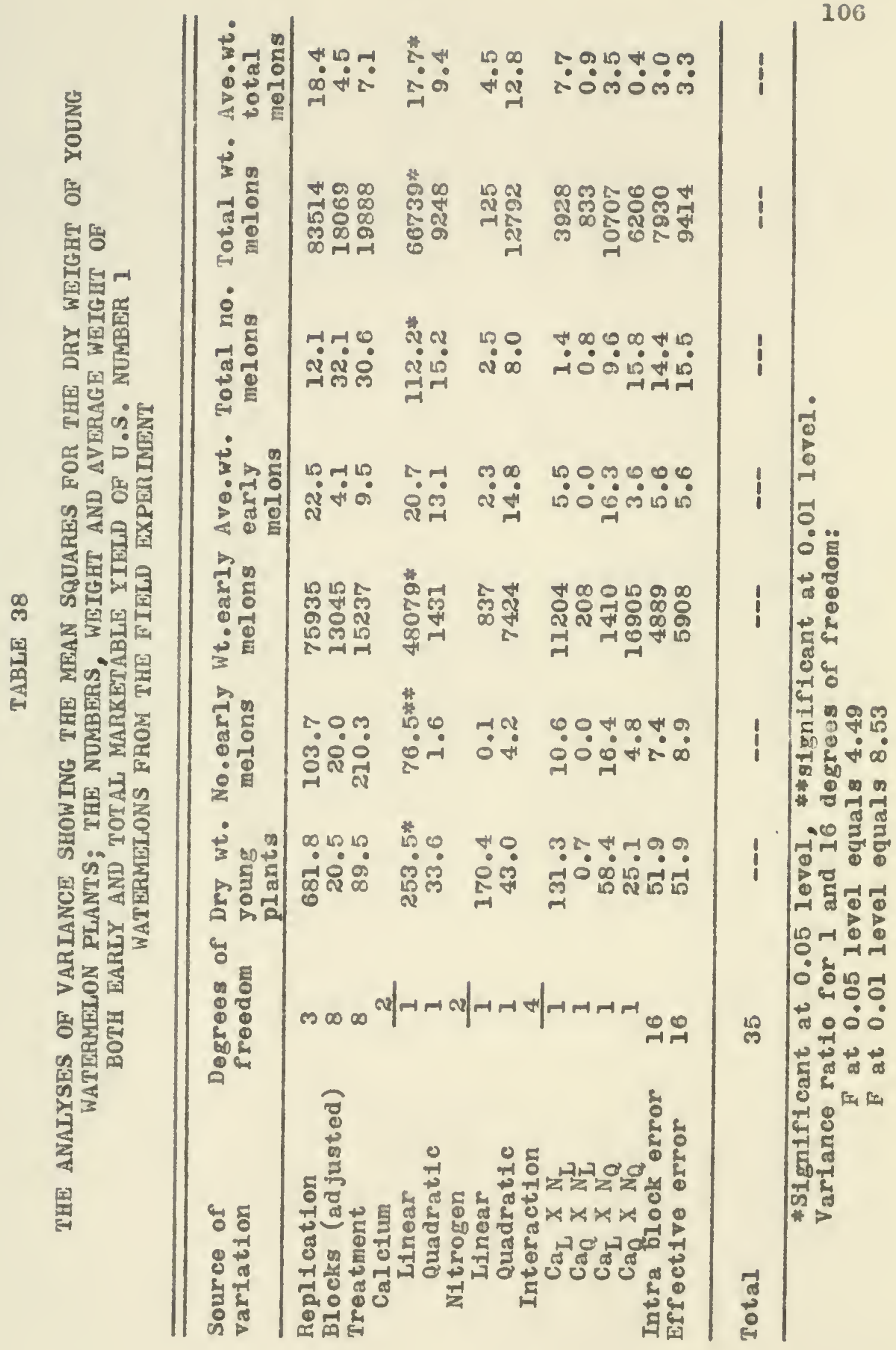




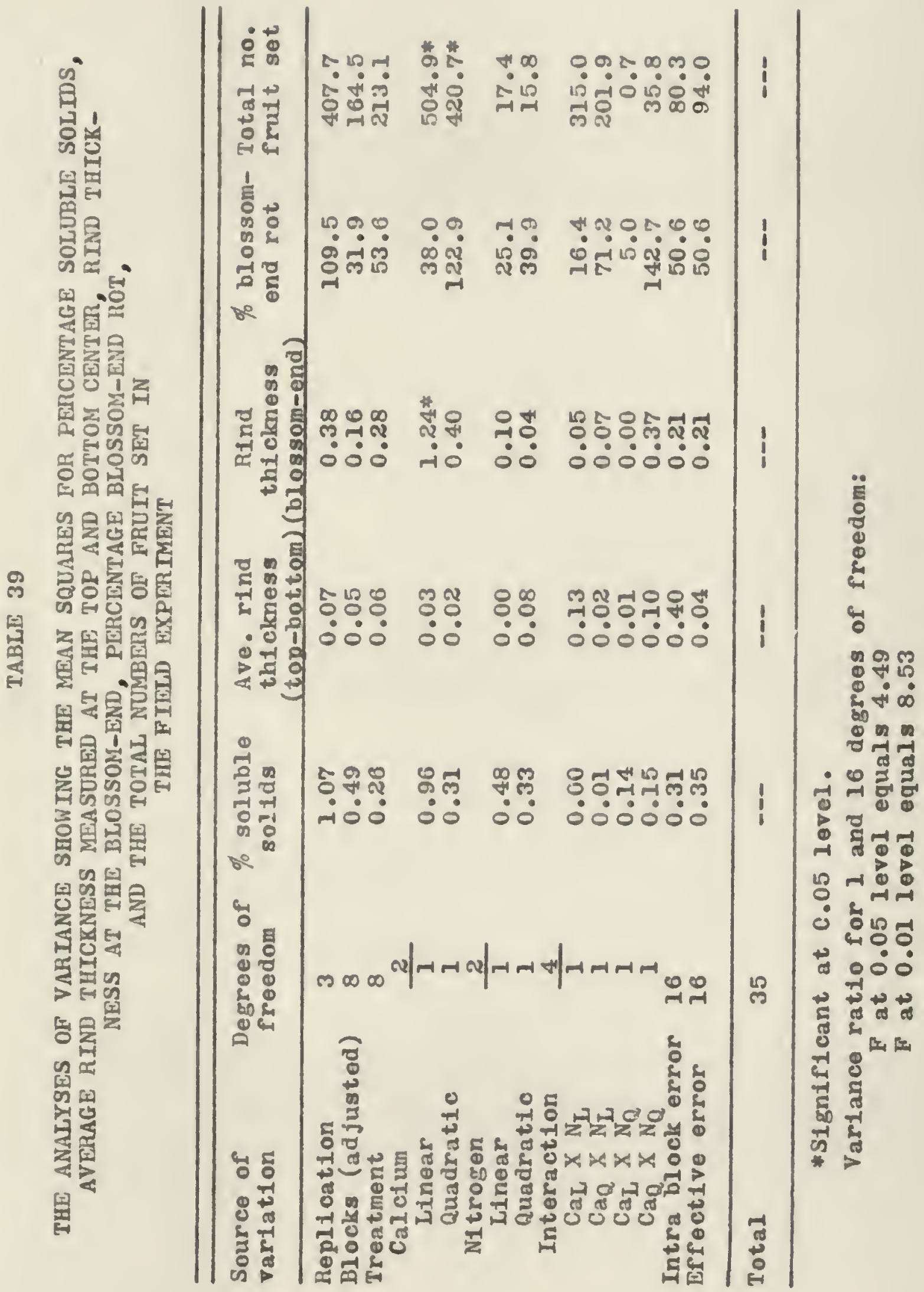




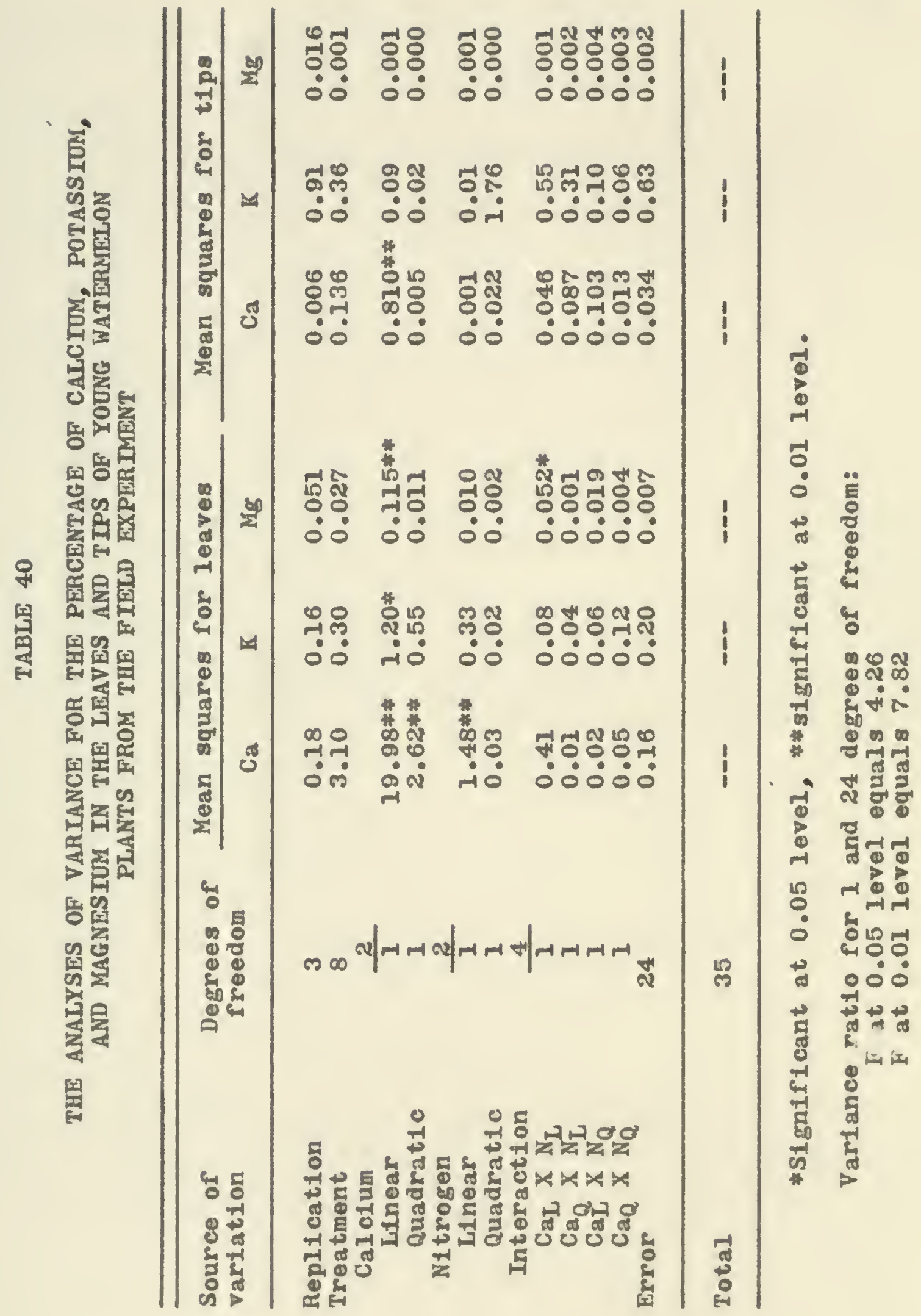




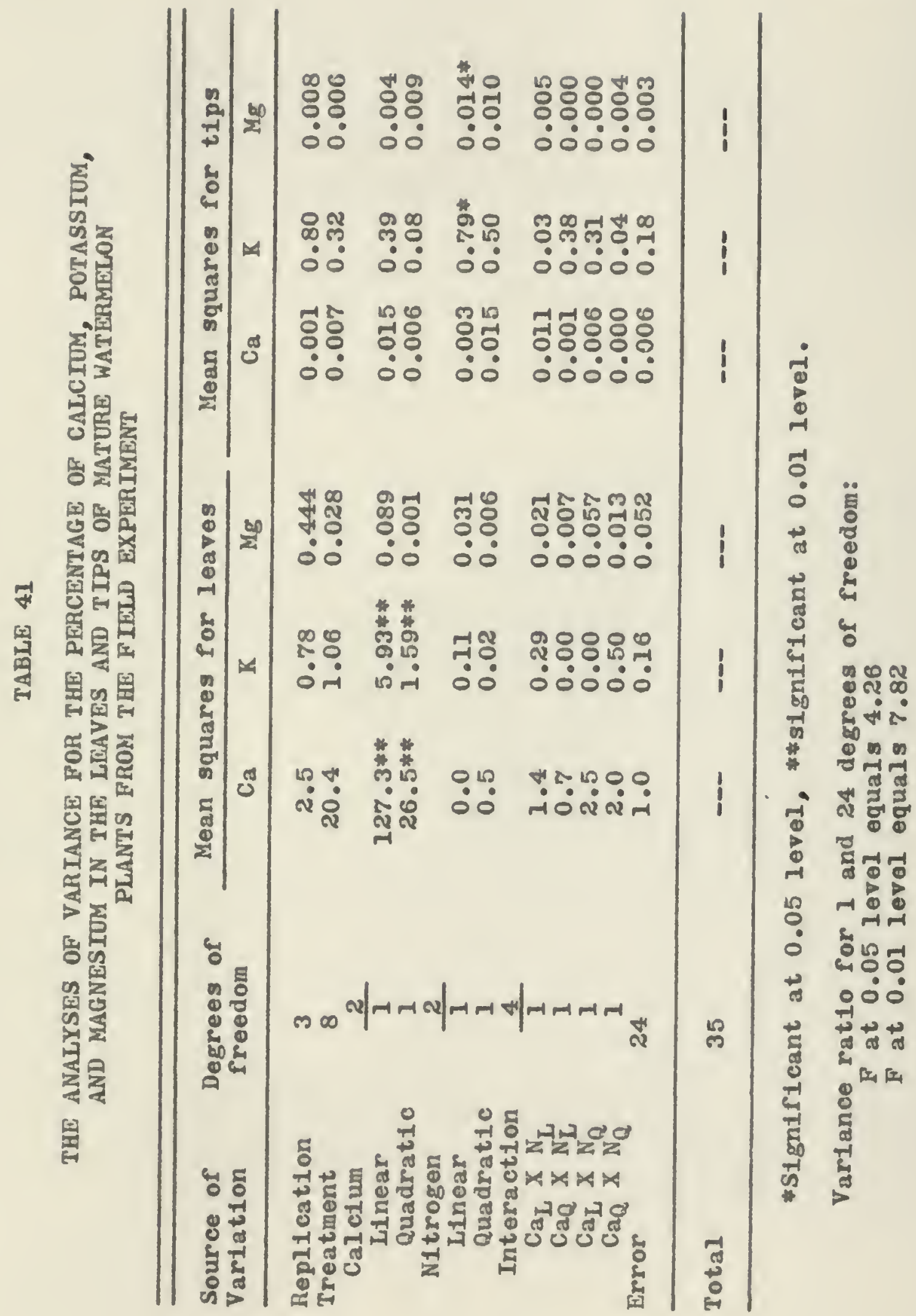




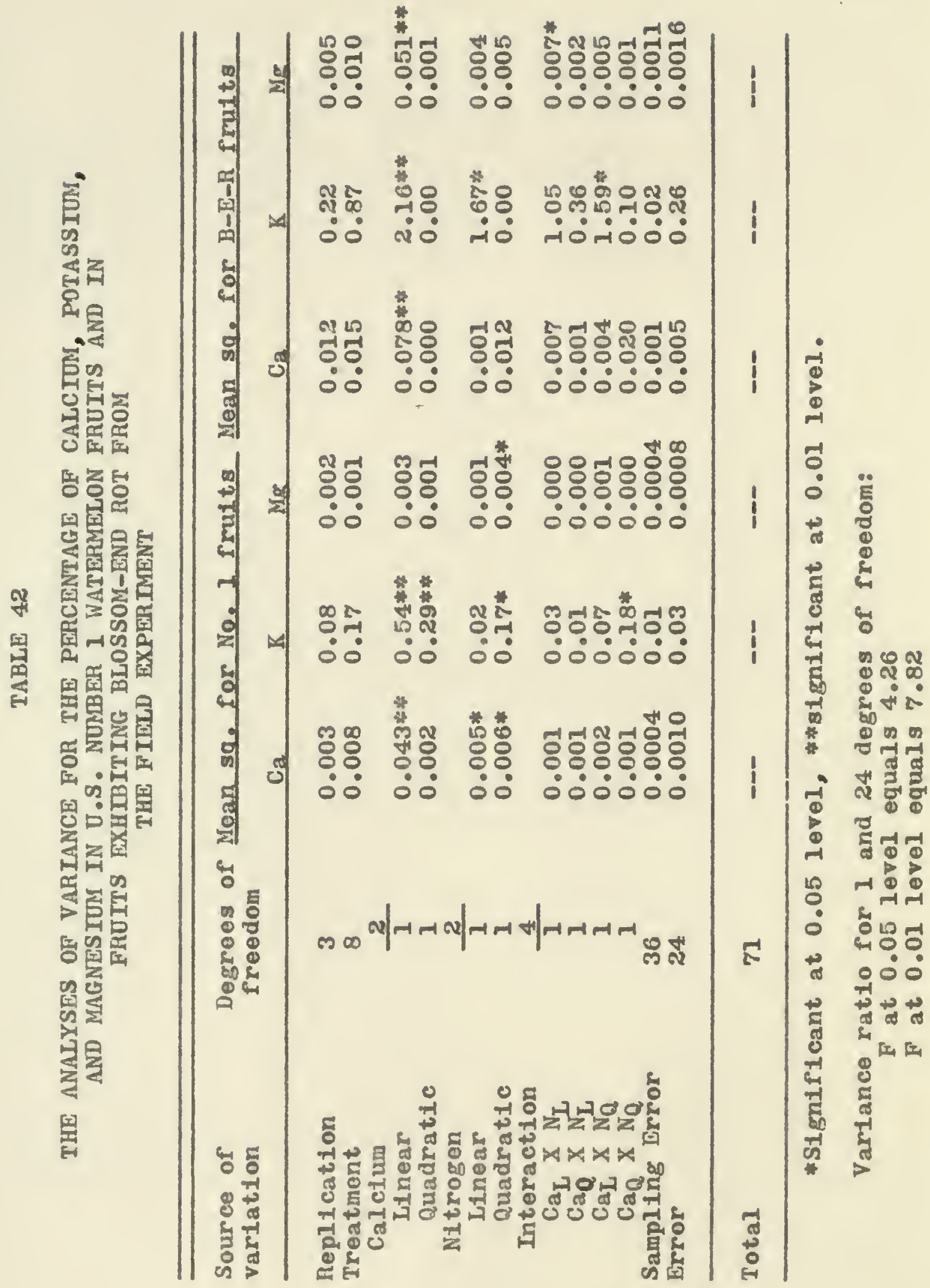




\section{BIOGRAPHICAL NOTES}

Wille Estel Waters was born September 19, 1931, in Smithtown, McCreary County, Kentuckg. He recelved his elementary education in the public school of Smithtown, Kentucky. He was graduated from McCreary County High School in 1950.

He entered Cumberland Junfor College in September, 1950, and was graduated In May, 1952. He entered the University of Kentucky the same year and was graduated in June, 1954, with a Bachelor of Sclence Degree In Agriculture.

He married Mary Ellzabeth Sumler of Sanford, Florida, in $\mathrm{Kay}, 1952$.

From June, 1954, to December, 1954, he worked as an Assistant County Agricultural Agent in Perry County, Kentucky. He served with the United States Army Medical Corps from December, 1954, to September, 1956.

He entered the Graduate School of the University of Kentucky in 1956, and completed the requirements for the Master of Sclence Degree in Agriculture in January, 1958. He entered Graduate School of the University of Florida in February, where he has since been working toward the degree of Doctor of Ph1losophy.

He was employed as a research assistant by the University of Kentucky Agricultural Experiment Station from 1956 
to 1958 and by the University of Florida Agricultural Experiment Station from 1958 to 1960.

He is a member of Alpha Zeta, Gamma Sigma Delta, Phi Kappa Pht, and an assoclate member of the Society of S1gma X1. 
This dissertation was prepared undor the direction of the chatrman of the candidate's supervisory comattee and has been approved by all members of that committec. It was submitted to the Dean of the College of Agriculture and to the Graduate Counc1l, and was approved as partial fulfillment of the requirements for the degree of Dootor of Phtlosophy •

January, 1960

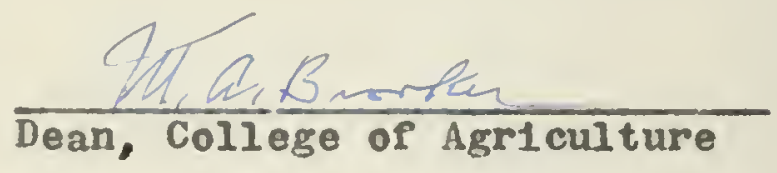

SUPERV ISORY COMRITTEE:

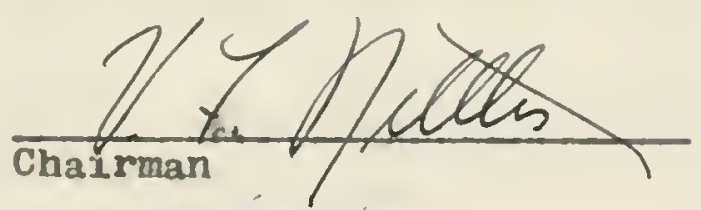

Dean, Graduate School

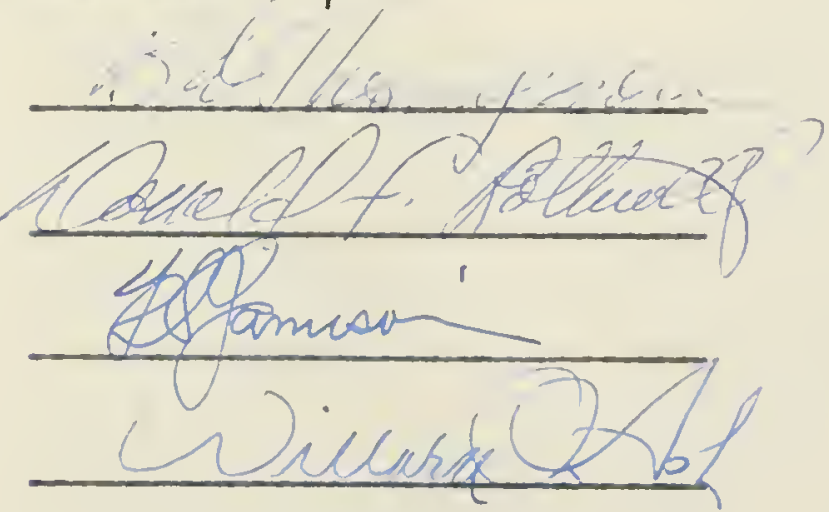




$$
\begin{aligned}
& \text { 1) } \geqslant: 12 \\
& \text { AGRI. } \\
& \text { CULTURAI } \\
& \text { UBRARY }
\end{aligned}
$$

31262085537800 